\title{
SEASONALITY OF GROUNDWATER RECHARGE IN THE BASIN AND RANGE PROVINCE, WESTERN NORTH AMERICA
}

\section{by}

\author{
Kirstin Lynn Neff \\ Copyright $\odot$ Kirstin Lynn Neff 2015 \\ A Dissertation Submitted to the Faculty of the

\section{DEPARTMENT OF HYDROLOGY AND WATER RESOURCES}

In Partial Fulfillment of the Requirements

For the Degree of

DOCTOR OF PHILOSOPHY

In the Graduate College

THE UNIVERSITY OF ARIZONA

2015 


\section{STATEMENT BY AUTHOR}

This dissertation has been submitted in partial fulfillment of the requirements for an advanced degree at the University of Arizona and is deposited in the University Library to be made available to borrowers under rules of the Library.

Brief quotations from this dissertation are allowable without special permission, provided that an accurate acknowledgement of the source is made. Requests for permission for extended quotation from or reproduction of this manuscript in whole or in part may be granted by the copyright holder.

SIGNED: Kirstin Lynn Neff 


\section{THE UNIVERSITY OF ARIZONA GRADUATE COLLEGE}

As members of the Dissertation Committee, we certify that we have read the dissertation prepared by Kirstin Neff, titled Seasonality of Groundwater Recharge in the Basin and Range Province, Western North America and recommend that it be accepted as fulfilling the dissertation requirement for the Degree of Doctor of Philosophy.

Date: $4 / 10 / 15$

Thomas Meixner

Date: $4 / 10 / 15$

Ty Ferré

Date: $4 / 10 / 15$

Jennifer McIntosh

Date: $4 / 10 / 15$

Willem van Leeuwen

Final approval and acceptance of this dissertation is contingent upon the candidate's submission of the final copies of the dissertation to the Graduate College.

I hereby certify that I have read this dissertation prepared under my direction and recommend that it be accepted as fulfilling the dissertation requirement.

Dissertation Director: Thomas Meixner

Date: $4 / 10 / 15$ 


\section{ACKNOWLEDGEMENTS}

Many thanks go to the people and organizations that supported me and helped move this research forward. First, thanks to my advisor, Tom Meixner, who first inspired me with the idea for this project, helped me prepare a successful grant to fund the work, and saw me through the long process of implementing our plan and bringing this dissertation into its final form. Thank you to the members of my committee, Ty Ferré, Jennifer McIntosh, and Willem van Leeuwen, for feedback that greatly improved this dissertation. Particularl thanks go to Hoori Ajami for her collaboration on this project at multiple stages, as well as her friendship. Thank you also to the members of the USGS John Wesley Powell Center Working Group on Western North America Groundwater Recharge, whose collaboration has been instrumental in developing this research.

Personal thanks go to my parents, who made my journey in science possible by supporting me in my decision to switch career fields immediately upon graduating from college. I yet again want to thank my dad for insisting that I take calculus, even when it seemed irrelevant to my future and contradictory to my present happiness. Thanks also go to my family, friends, and mentors who have encouraged me throughout this transformation. I want to thank the members of the UA Science: Sky School team for keeping me sane in these last two years of dissertating by giving me an outlet to share my science with a wider, younger, more invigorating audience than is accessible to most academics. Particular thanks go to my Monday morning dissertation writing team and Cafe Passé, whose commitment to being in the same place and time every week to at least pretend to write absolutely resulted in my finishing this dissertation in a timelier manner. Special thanks go to Andrew and Corbie for providing daily support and diversion, to Braden for helping me keep things in perspective, to Marisela for always having my back, and the Dinner Party ladies (Callie, Cristin, Katherine, Lauren, Nika, and Sierra) for making life sweet (and savory).

Funding for this research was provided by two National Science Foundation grants awarded to University of Arizona faculty (NSF-DEB-1010495, NSF-DEB-103938). This dissertation was developed under STAR Fellowship Assistance Agreement no. FP91749101-0 awarded by the U.S. Environmental Protection Agency (EPA). It has not been formally reviewed by EPA. The views expressed in this dissertation are solely those of Kirstin L. Neff, and EPA does not endorse any products or commercial services mentioned in this dissertation. 


\section{DEDICATION}

For my parents, Daniel and Carolyn, and the Drs. Neff who proceeded me: Emery Bowers Neff, M.D., Richmond Clark Neff, Ph.D., and Mary Susan Neff, Ph.D. 
TABLE OF CONTENTS

ABSTRACT

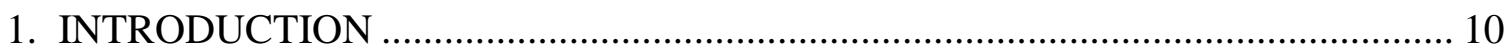

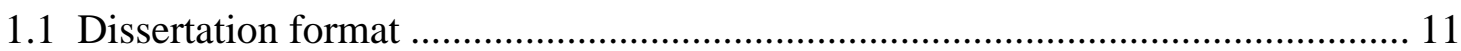

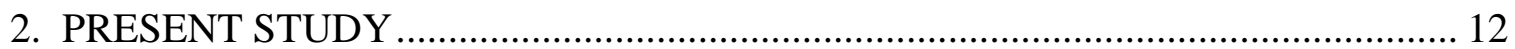

2.1 Summary of Paper 1: Climate and Geographic Controls on Groundwater Recharge and Baseflow: a Geochemical Analysis of the Río San Miguel Basin, Sonora, Mexico

2.2 Summary of Paper 2: Seasonality of Groundwater Recharge in the Basin and Range Province, Western North America...................................................................... 13

2.3 Summary of Paper 3: Seasonal Hydrologic Controls on Riparian Corridor Productivity in the Arid and Semi-arid Western United States ...................................... 13

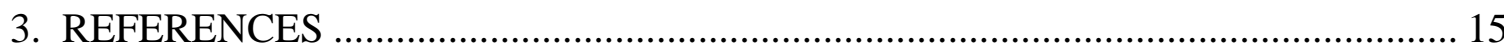

APPENDIX A: Climate and Geographic Controls on Groundwater Recharge and Baseflow: a Geochemical Analysis of the Río San Miguel Basin, Sonora, Mexico …… 17

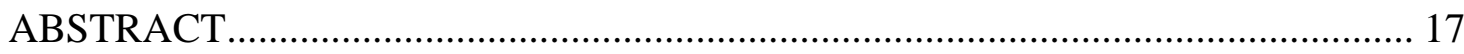

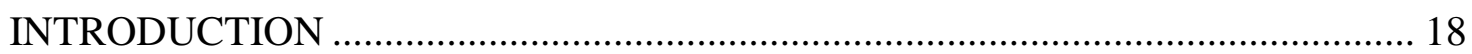

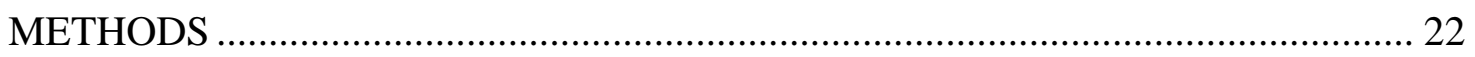

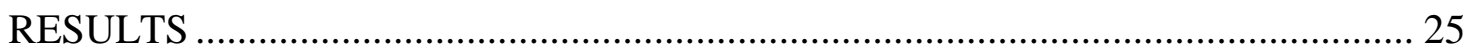

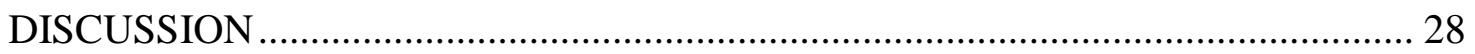

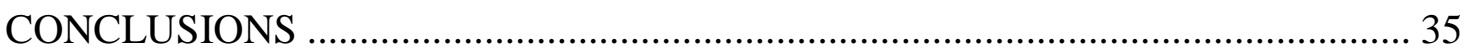

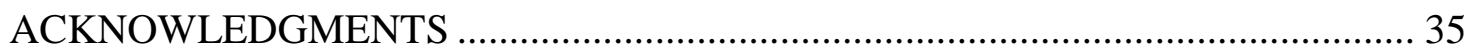

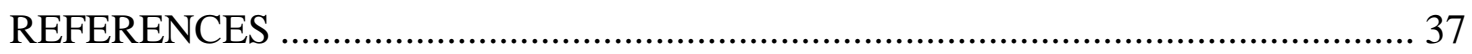

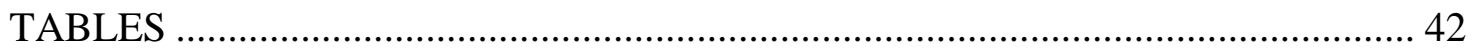

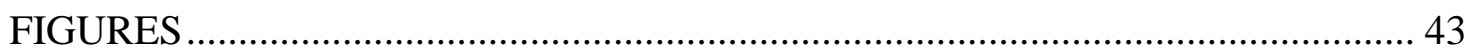

APPENDIX B: Seasonality of Groundwater Recharge in the Basin and Range Province, Western North America ……………………………............................................ 53

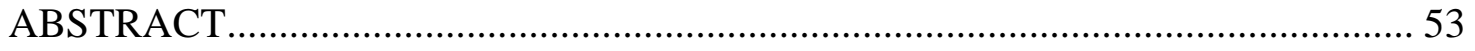

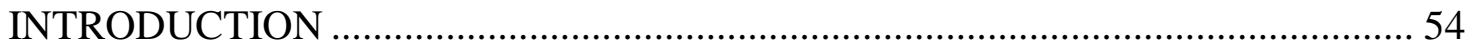

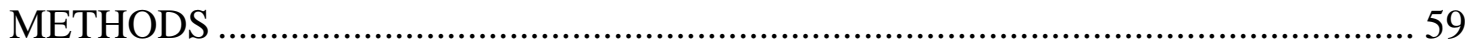

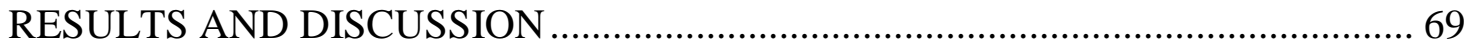

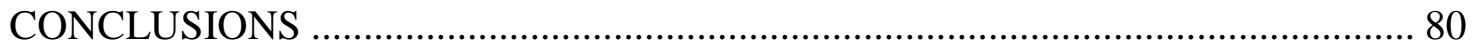

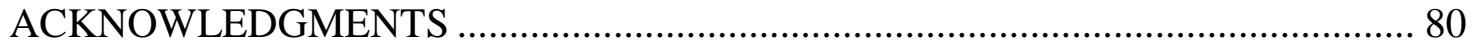

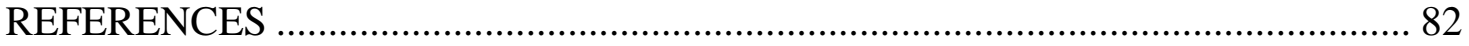


TABLE OF CONTENTS - continued

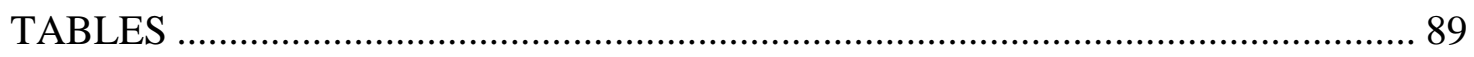

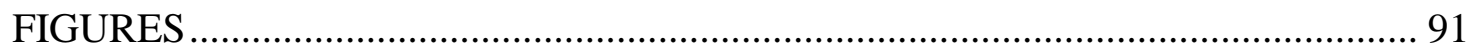

APPENDIX C: Seasonal Hydrologic Controls on Riparian Corridor Productivity in the Arid and Semi-arid Western United States ...................................................................... 97

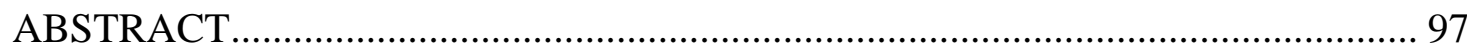

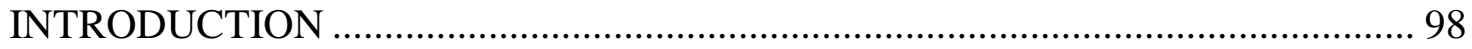

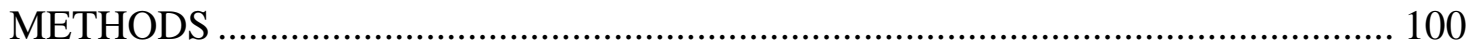

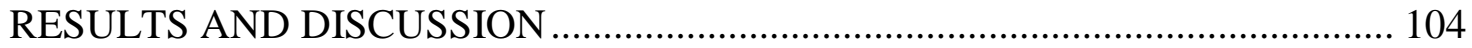

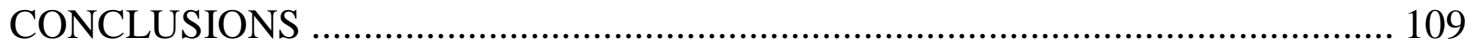

ACKNOWLEDGMENTS ……………………………………………….... 110

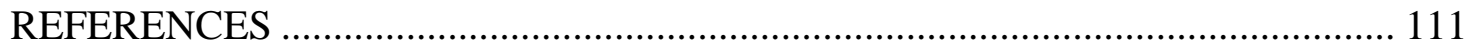

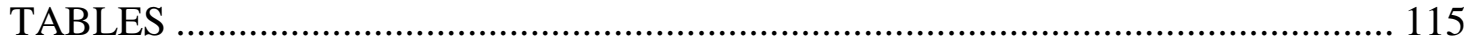

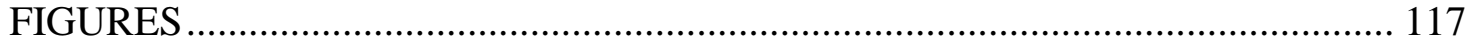




\begin{abstract}
Alluvial groundwater systems are an important source of water for communities and biodiverse riparian corridors throughout the arid and semi-arid Basin and Range Geological Province of western North America. These aquifers and their attendant desert streams have been depleted to support a growing population, while projected climate change could lead to more extreme episodes of drought and precipitation in the future. The only source of replenishment to these aquifers is recharge. This dissertation builds upon previous work to characterize and quantify recharge in arid and semi-arid basins by characterizing the intra-annual seasonality of recharge across the Basin and Range Province, and considering how climate change might impact recharge seasonality and volume, as well as fragile riparian corridors that depend on these hydrologic processes. First, the seasonality of recharge in a basin in the sparsely-studied southern extent of the Basin and Range Province is determined using stable water isotopes of seasonal precipitation and groundwater, and geochemical signatures of groundwater and surface water. In northwestern Mexico in the southern reaches of the Basin and Range, recharge is dominated by winter precipitation $(69 \% \pm 42 \%)$ and occurs primarily in the uplands. Second, isotopically-based estimates of seasonal recharge fractions in basins across the region are compared to identify patterns in recharge seasonality, and used to evaluate a simple water budget-based model for estimating recharge seasonality, the normalized seasonal wetness index (NSWI). Winter precipitation makes up the majority of annual recharge throughout the region, and North American Monsoon (NAM) precipitation has a disproportionately weak impact on recharge. The NSWI does well in estimating recharge seasonality for basins in the northern Basin and Range, but less so in basins that experience NAM precipitation. Third, the seasonal variation in riparian and non-riparian
\end{abstract}


vegetation greenness, represented by the normalized difference vegetation index (NDVI), is characterized in several of the study basins and climatic and hydrologic controls are identified. Temperature was the most significant driver of vegetation greenness, but precipitation and recharge seasonality played a significant role in some basins at some elevations. Major contributions of this work include a better understanding of recharge in a monsoon-dominated basin, the characterization of recharge seasonality at a regional scale, evaluation of an estimation method for recharge seasonality, and an interpretation of the interaction of seasonal hydrologic processes, vegetation dynamics, and climate change. 


\section{INTRODUCTION}

Changing climate will influence the hydrologic cycle in ways that are not fully understood, threatening already scarce freshwater resources throughout the western United States (Milly et al., 2008). In order to anticipate how freshwater systems might respond to changes in climate, it is necessary to more fully characterize the movement of water through the terrestrial system by quantifying and describing the partitioning of rainfall into groundwater recharge, surface runoff, and evapotranspiration. In the Western U.S., where many communities are dependent on groundwater resources for human consumption, and perennial desert streams fed by groundwater give life to vibrant riparian corridors (Leenhouts el al, 2006), it is particularly critical to understand the current groundwater recharge regimes and how those regimes might shift in the face of climate change.

Prior studies of groundwater recharge in the western deserts of the U.S. have found that despite up to two-thirds of yearly precipitation falling during high-intensity, convective summer monsoon storms in the North American Monsoon (NAM) zone, this type of precipitation contributes comparatively less to groundwater recharge (Wilson and Guan, 2004). Methods for partitioning groundwater recharge into mountain system recharge and flood recharge, and their relationship to streamflow have been thoroughly developed, and include the water budget method (Vivoni et al., 2006), empirical modeling (Ajami et al., 2011\&2012), coupled land-surface modeling (Abdulaziz et al., 2012; Serrat-Capdevila et al., 2013), geochemical methods (Plummer et al., 2004; Manning, 2011), and isotopic methods (e.g., Winograd et al., 1998; Eastoe et al., 2004; Thiros and Manning, 2004; Anderson et al., 2006; Baillie et al., 2007; Blasch and Bryson, 2007; Druhan et al., 2008; Wahi et al., 2008; Jasechko et al., 2014). 
This dissertation aims to expand our understanding of recharge seasonality in these arid and semi-arid systems by characterizing recharge in a more southern, monsoon-dominated basin and describing the spatial variation in recharge seasonality across the climate gradient of this region. Understanding the regional patterns in recharge seasonality allows for the evaluation of a new index based on climatic data to estimate the seasonality of recharge without extensive sampling campaigns. The ability to model recharge seasonality would improve parameterization of hydrologic models used to project future water resources availability under climate change. Another aim of this dissertation is to evaluate the relationship between the timing of precipitation and recharge in these basins, and seasonal cycles in riparian vegetation productivity. A better understanding of the hydrologic and climatic controls on riparian vegetation could help inform water management decisions with an eye toward maintaining these important corridors of biodiversity.

Results from these studies suggest that although winter precipitation throughout the Basin and Range has a greater recharge efficiency than summer precipitation and dominates mountain-system recharge, summer precipitation plays an important role in monsoon-dominated basins and in sustaining riparian vegetation.

\subsection{Dissertation format}

This document contains a summary chapter entitled Present Study, in which the three manuscripts that will be submitted for publication are briefly described, and general conclusions arising from the manuscripts are discussed. The appendices following the initial chapter contain the three manuscripts, and describe the motivations, methods, results and discussions of each individual chapter. 


\section{PRESENT STUDY}

The present study is divided into three manuscripts that are included in this dissertation as Appendices A, B and C. The manuscripts are arranged in an order of progressive concepts. Appendix A involves the application of established stable isotope methods for characterizing recharge seasonality in a poorly-studied region and geochemical techniques for identifying recharge zones. Appendix B compares the results of that basin-scale study to those from basins across the Basin and Range Geological Province so that regional trends in recharge seasonality and their implications for climate change impacts to groundwater resources may be evaluated. Finally, Appendix C takes the knowledge gained about regional patterns in recharge seasonality and examines its relationship to seasonal variations in the productivity of riparian corridors in this arid and semi-arid region.

\subsection{Summary of Paper 1: Climate and Geographic Controls on Groundwater Recharge and Baseflow: a Geochemical Analysis of the Río San Miguel Basin, Sonora, Mexico}

The primary objective of this paper was to characterize recharge sources and seasonality in the Río San Miguel Basin, Sonora, Mexico using isotopic and geochemical methods. Past studies in the Basin and Range Province have shown that recharge is dominated by winter precipitation (e.g., Simpson et al., 1972; Winograd et al., 1998), but southern basins influenced by NAM precipitation have a greater contribution to recharge from summer precipitation (e.g., Wahi et al., 2008). Results of this study are 1) winter precipitation contributes $69 \% \pm 42 \%$ of annual recharge in the San Miguel, 2) recharge occurs primarily in headwater and upland sub-basins, with less new water entering in lower sub-basins where water is well-mixed and relatively homogenous, and 3) the 
isotopic composition of individual storms and event water can vary greatly, perhaps depending on the source of precipitation.

\subsection{Summary of Paper 2: Seasonality of Groundwater Recharge in the Basin and Range Province, Western North America}

The primary objectives of this paper was to characterize recharge seasonality across a climatic gradient in the arid and semi-arid Basin and Range Province using isotopically-derived fractions of winter recharge for basins throughout the domain, and to test a new climatic index for estimating recharge seasonality. Results of this study are 1) basins that experience more summer (monsoon) precipitation have a greater contribution of summer precipitation to recharge, but all basins are still dominated by winter recharge, 2) the marked difference between the timing of precipitation and the timing of recharge in the southern Basin and Range illustrates the weak impact of the NAM on recharge in the region, 3) the NSWI does well in estimating recharge seasonality for some basins, primarily in the northern Basin and Range and in basins without significant quick runoff from summer precipitation events, and 4) projected declines (increases) in winter precipitation in the southern (northern) Basin and Range would lead to decreased (increased) total annual recharge.

\subsection{Summary of Paper 3: Seasonal Hydrologic Controls on Riparian Corridor Productivity in the Arid and Semi-arid Western United States}

The primary objective of this paper was to examine the relationship between recharge seasonality, as determined in the previous paper, and seasonal variations in riparian vegetation productivity, represented as NDVI. The seasonality of precipitation and annual temperatures ranges were also examined as climatic factors potentially impacting the productivity of riparian corridors. Results of this study are 1) seasonal variations in riparian NDVI are not significantly correlated with the seasonality of 
recharge, 2) seasonality of precipitation and annual temperature ranges had a greater impact on seasonal riparian NDVI changes, and 3) summer precipitation likely plays an important role in riparian productivity. 


\section{REFERENCES}

Abdulaziz AM, Hurtado JM, Faid A. 2012. Hydrogeological characterization of Gold Valley: an investigation of precipitation recharge in an intermountain basin in the Death Valley region, California, USA. Hydrogeology Journal 20(4): 701-718.

Ajami H, Meixner T, Dominguez F, Hogan JF, Maddock III T. 2012. Seasonalizing mountain system recharge in semi-arid basins--climate change impacts. Ground Water 50(4): 585-597.

Ajami H, Troch PA, Maddock III T, Meixner T, Eastoe C. 2011. Quantifying mountainblock recharge by means of catchment-scale storage-discharge relationships, Water Resources Research 47: W04504, DOI: 10.1029/2010WR009598.

Baillie MN, Hogan JF, Ekwurzel B, Wahi AK, Eastoe CJ. 2007. Quantifying water sources to a semi-arid riparian ecosystem, San Pedro River, Arizona. Journal of Geophysical Research 112, G03S02, DOI:10.1029/2006JG000263.

Blasch KW, Bryson JR. 2007. Distinguishing sources of ground water recharge by using $\delta \mathrm{D}$ and $\delta^{18}$ O. Ground Water 45(3): 293-308. DOI: 10.1111/j.1745-6584.2006.00289.x.

Druhan JL, Hogan JF, Eastoe CJ, Hibbs BJ, Hutchison WR. 2008. Hydrogeologic controls on groundwater recharge and salinization: a geochemical analysis of the northern Hueco Bolson aquifer, Texas, USA. Hydrogeology Journal 16: 281-296. DOI: DOI 10.1007/s10040-007-0222-9.

Eastoe CJ, Gu A, Long A. 2004. The origins, ages and flow paths of groundwater in Tucson Basin: results of a study of multiple isotope systems. In Groundwater Recharge in a Desert Environment: the Southwestern United States, Hogan JF, Phillips FM, Scanlon BR (eds.). American Geophysical Union: Washington, D.C.: 217-234.

Eastoe CJ, Hibbs BJ, Olivas A, Hogan JF, Hawley J, Hutchison WR. 2008. Isotopes in the Hueco Bolson aquifer, Texas (USA) and Chihuahua (Mexico): local and general implications for recharge sources in alluvial basins. Hydrogeology Journal 16(4): 737747.

Jasechko S, Birks SJ, Gleeson T, Wada Y, Fawcett PJ, Sharp ZD, McDonnell JJ, Welker JM. 2014. The pronounced seasonality of global groundwater recharge. Water Resources Research 50: 8845-8867, doi:10.1002/2014WR015809.

Leenhouts JM, Stromberg JC, Scott RL. 2006. Hydrologic requirements of and consumptive ground-water use by riparian vegetation along the San Pedro River, Arizona. U. S. Geological Survey, Scientific Investigations Report 2005-5163.

Manning AH. 2011. Mountain-block recharge, present and past, in the eastern Española Basin, New Mexico, USA. Hydrogeology Journal 19: 379-397. 
Manning, AH, Solomon DK. 2005. An integrated environmental tracer approach to characterizing groundwater circulation in a mountain block. Water Resources Research 41, W12412, doi:10.1029/2005WR004178.

Milly PCD, Betancourt J, Falkenmark M, Hirsch RM, Kundzewicz ZW, Lettenmaier DP, Stouffer RJ. 2008. Stationarity is dead: whither water management? Science 319(5863): 573-574.

Plummer LN, Sanford WE, Bexfield LM, Anderholm SK, Busenberg E. 2004. Using geochemical data and aquifer simulation to characterize recharge and groundwater flow in the Middle Río Grande Basin, New Mexico, in Groundwater Recharge in a Desert Environment: the Southwestern United States, Hogan JF, Phillips FM, Scanlon BR (eds.). American Geophysical Union, Washington D.C., pp. 185-216.

Serrat-Capdevila A., Valdés JB, Pérez JG, Baird K, Mata LJ, Maddock III T. 2007. Modeling climate change impacts--and uncertainty--on the hydrology of a riparian system: The San Pedro Basin (Arizona/Sonora). Journal of Hydrology 347(1-2), 48-66.

Simpson ES, Thorud DB, Friedman I. 1972. Distinguishing seasonal recharge to groundwater by deuterium analysis in southern Arizona. In World Water Balance, Proceedings of the 1970 Reading Symposium, International Association of Scientific Hydrology. UNESCO-WMO; 623-633.

Thiros SA, Manning AH. 2004. Quality and sources of ground water used for public supply in Salt Lake Valley, Salt Lake County, Utah, 2001. U.S. Geol. Surv. Water Resour. Invest. Rep., 03-4325; 95.

Vivoni ER, Bowman RS, Wyckoff RL, Jakubowski RT, Richards KE. 2006. Analysis of a monsoon flood event in an ephemeral tributary and its downstream hydrologic effects. Water Resources Research 42(3): W03404, doi:10.1029/2005WR004036.

Wahi AK, Hogan JF, Ekwurzel B, Baillie MN, Eastoe CJ. 2008. Geochemical quantification of semi-arid mountain recharge. Ground Water 46(3): 414-425.

Wilson JL, Guan H. 2004. Mountain-block hydrology and mountain-front recharge. In Groundwater Recharge in a Desert Environment: the Southwestern United States, Hogan JF, Phillips FM, Scanlon BR (eds.). American Geophysical Union: Washington D.C.; 113-137.

Winograd IJ, Riggs AC, Coplen TB. 1998. The relative contributions of summer and cool-season precipitation to groundwater recharge, Spring Mountains, Nevada, USA. Hydrogeology Journal 6(1): 77-93. 


\title{
APPENDIX A: Climate and Geographic Controls on Groundwater Recharge and Baseflow: a Geochemical Analysis of the Río San Miguel Basin, Sonora, Mexico
}

\author{
Kirstin Neff ${ }^{1}$, Lissette De La Cruz ${ }^{1}$, Thomas Meixner ${ }^{1}$, Miguel Rangel-Medina Medina ${ }^{2}$, \\ Anho Taylor ${ }^{2}$, Carlos Pineda ${ }^{2}$, Irlanda Grijalva ${ }^{2}$ \\ ${ }^{1}$ University of Arizona, Department of Hydrology and Water Resources, Tucson, AZ, USA \\ ${ }^{2}$ University of Sonora, Department of Geology, Hermosillo, Sonora, Mexico
}

\begin{abstract}
The seasonality of groundwater recharge has been shown to be dominated by winter precipitation in many aquifers of the Basin and Range Geologic Province. The Río San Miguel Basin is a rural watershed in Sonora, Mexico located in the southern-most extent of the Basin and Range, where recharge studies are scarce. Major ion chemistry and stable water isotopes are analyzed for groundwater and surface water samples taken up and down the length of the river from May 2006 to October 2012 to determine the sources and timing of groundwater recharge in the basin. Although 60-67\% of annual precipitation occurs during summer months due to the North American Monsoon (NAM), stable water isotope data shows that $69 \% \pm 42 \%$ of groundwater recharge occurs as a result of winter precipitation. Major ion data indicate that recharge occurs primarily in the upper part of the basin, and groundwater is well-mixed by the time it passes into the lower-most sub-basin. Significant variability in the isotopic composition of storm flows suggest a variety of sources of monsoonal precipitation occur in the basin.
\end{abstract}




\section{INTRODUCTION}

In studies throughout the arid and semi-arid Basin and Range Province of Western North America, stable water isotope values of seasonal precipitation and groundwater have been used to show that winter precipitation and mountain system recharge processes dominate annual groundwater recharge (Winograd et al., 1998; Rose et al., 2003; Anderson et al., 2006), even in basins with a strong influence from the North American Monsoon (NAM) on annual precipitation (Simpson et al., 1972; Eastoe et al., 2004; Blasch and Bryson, 2007; Eastoe et al., 2008; Wahi et al., 2008). Climatic and hydrological processes combine to create recharge regimes characterized by seasonal variations in recharge volume and timing. In order to better understand how regionalscale climate forcings and basin-scale hydrogeological circumstances impact the timing and quantity of recharge, it is useful to compare recharge regimes between geologically similar basins across a climatic gradient. In the southern reaches of the Basin and Range Province in northern Mexico, where the NAM has the greatest influence on annual precipitation (Dominguez et al., 2009), no studies to characterize the recharge regime of this type of basin have been conducted.

The U.S.-Mexico border region provides a useful case study to compare how climate challenges to water resource sustainability play out in different sociocultural, economic, and political settings. This paper examines groundwater recharge in the Río San Miguel Basin, a rural, predominantly agricultural river basin in the northwestern Mexican state of Sonora. Though vegetation dynamics and evapotransipiration have been well-studied in this basin, the hydrology of recharge and stream-aquifer interactions that impact vegetation has been less studied (Méndez-Barroso et al., 2009\&2014). 
The previous studies of this kind conducted in the U.S. have demonstrated a trend of increasing recharge contribution from summer precipitation southward into the NAM region. As the southernmost basin studied in this region, it is expected that the Río San Miguel Basin will have a proportion of winter recharge less than or equal to southern Basin and Range sites in the U.S. with a monsoon influence. This hypothesis is based on the expectation that as basins common to the same geological region, this southernmost basin and its northern neighbors will share similar recharge processes and pathways. In the Río San Miguel Basin, does a stronger monsoon translate to greater summer recharge than in more northern basins? What recharge locations and processes dominate in the basin?

\section{Recharge in Basin and Range aquifers}

The Río San Miguel Basin is located in the Basin and Range Geological Province of western North America, which is characterized by a series of horst and graben basins trending north-south from the Sierra Nevada and Sierra Madre mountain ranges in the west to the Colorado plateau and the Río Grande Valley in the east (McPhee, 1980). These basins contain highly productive groundwater aquifers in the alluvial fill of the valleys, making them a critical source of freshwater for human use in an arid and semiarid region.

Recharge is difficult to measure directly, since much of the water that infiltrates in semi-arid basins never actually reaches the water table, but is transpired by plants or reevaporated back to the atmosphere (de Vries and Simmers, 2002). There can be a variety of different recharge pathways in a basin, with different recharge rates. The different recharge pathways include mountain-block bedrock zones, mountain-front alluvial fan zones, diffuse basin recharge, and near-river floodplain recharge (Wilson and Guan, 
2004; Meixner et al., in review). Estimating recharge in a basin involves creating a basin water budget and deducing recharge from measureable quantities such as annual precipitation, runoff and evapotranspiration, as well as infiltration and tracer tests to determine zones of high and low recharge rates. Another method to estimate periodic fluctuations in recharge uses long-term data on water table levels (Dickinson et al., 2004).

Since climate interacts differently with each of the recharge pathways occurring in these basins due to geology, topography, and vegetation dynamics, it is essential to identify which pathways are contributing most to annual recharge in order to understand how climate change might alter that balance.

\section{Study area}

The Río San Miguel Basin is a rural tributary watershed to the Río Sonora in north-central Sonora, Mexico covering 4,220 km² (CONAGUA) (Figure 1). It is located in the southern-most extent of the Basin and Range, where the Sonoran Desert meets the Sierra Madre Occidental. The Río San Miguel has its headwaters in the Sierra Azul, from which it flows south and west to Hermosillo, the capital of Sonora. It passes through several small municipalities, the largest of which is Rayón (Figure 2). The primary industry in these towns is agriculture, and both shallow and deep wells have been developed to supplement river diversions for irrigation and the filling of stock ponds.

\section{Climatology}

As compared to other Basin and Range watersheds, local climatology in the San Miguel Basin is under greater influence of the NAM. Analysis of meteorological data collected for over five decades in the municipalities of Cucurpe and Rayón, and at the river gauging station El Cajón indicate variations in mean annual precipitation along the north-south gradient of the river course (Rangel-Medina et al., in-prep). The 
northernmost site, Cucurpe, experienced a mean annual rainfall of $530.3 \mathrm{~mm}, 59.6 \%$ of which occurred during the late summer monsoon season of July to September. At Rayón, in the center of the basin, mean annual precipitation was $498.1 \mathrm{~mm}, 66.4 \%$ of which occurred during the monsoon season. At the southern end of the basin at El Cajón, mean annual precipitation was $416.4 \mathrm{~mm}$, comprised of $66.8 \%$ monsoon precipitation. Mean annual precipitation increases upstream, while the relative contribution of monsoon precipitation increases downstream.

One issue in estimating the amount of recharge in a basin is climatic variability. In addition to geography, recharge is dependent upon atmospheric factors such as precipitation and temperature. The amount of recharge in any year varies depending on climate patterns. With climate change, the amount of precipitation from year to year could vary, affecting the amount of recharge that occurs (Castro et al., 2012; Dominguez et al., 2012). The seasonality, or timing, of precipitation over the year could also impact the amount of recharge if the ratio of precipitation that becomes recharge to precipitation that becomes runoff or evapotranspiration varies between seasons.

Beyond climatic variation within basins, there is variation in climate across the domain of the Basin and Range Province, with more southern basins showing greater influence from the NAM. Therefore, the seasonality of recharge varies throughout the region, and comparing basins as they are today can be a useful tool for predicting how basins will change under altered climate (Grimm et al., 1997). Downscaled global circulation models indicate the possibility that in the future, the NAM will extend its influence further north, resulting in a stronger monsoon signal in the southwestern U.S. 
(Castro et al., 2012). Thus, current recharge conditions in the San Miguel Basin could inform forecasts of future groundwater availability in basins of the southwestern U.S. Hydrogeology

Like other Basin and Range watersheds, the San Miguel Basin is characterized by north-south trending mountain ranges and valleys created by longitudinal faulting. The horst structures are typically composed of intrusive igneous and metamorphic bedrock, while the grabens contain tertiary and quaternary alluvial and sedimentary deposits, and particularly conglomerates of the Báucarit Formation (CONAGUA, 2008).

The aquifer is contained in high-permeability unconsolidated sands, gravels, and outcroppings restricted to fluvial zones along the river and its tributaries, which are surrounded by impermeable granite, andesite, and rhyolite outcroppings (CONAGUA, 2008). In upper parts of the watershed and at the base of alluvial sediments, water is contained in bedrock fractures. Wells that permeate these areas have produced waters of abnormally high temperatures. At several points, the river course passes through impermeable igneous bedrock which serves to divide the multiple sub-basins contained in the San Miguel watershed. These areas are zones of upwelling of groundwater into the stream channel as bedrock intrudes upward, and they occur near the towns of Cucurpe, Meresichic, and Rayón. South of Rayón, the river course becomes entrenched in bedrock layers, with perennial flow occurring at the El Cajón gauge located between Rayón and San Miguel de Horcasitas.

\section{METHODS}

\section{Data collection}

In the San Miguel Basin, surface water and groundwater samples were collected in the months of May, July, and February from May 2006 until February 2008, and again 
in January 2009, June 2011, and February, June, July, and October 2012. These sampling times were chosen to capture the three seasons of the basin: dry early summer (AprilJune), wet late summer monsoon season (July-October), and wet winter (NovemberMarch). Samples were taken at several sites along the river course and from basin wells near the towns of Cucurpe, Opodepe, Meresichic, Santa Margarita, Rayón, and San Miguel de Horcasitas (Figure 3).

When possible, samples were filtered in the field using $0.45 \mu \mathrm{m}$ MCE membrane filters. Some monsoon flood flow samples were filtered before analysis in the lab using vacuum-driven stand filtration systems. Filtered samples were analyzed for major cations using an inductively coupled plasma optical emissions spectrometer (ICP OES), and for anions using a Dionex Ion Chromatograph (IC) located at the University of Arizona. $\delta^{18} \mathrm{O}$ and $\delta \mathrm{D}$ values were measured using a gas-source isotope ratio mass spectrometer according to standard methods for oxygen (Craig, 1957) and hydrogen (Gehre et al., 1996). The standard used for comparison was Vienna Standard Mean Ocean Water (VSMOW; Gonfiantini, 1978).

The $\delta^{18} \mathrm{O}$ and $\delta \mathrm{D}$ values of summer (April-May) and winter (October-March) precipitation used in this study were determined using Isoscapes Modeling, Analysis and Preciption (IsoMAP), a precipitation isotope modeling program which uses observed stable water isotopes in precipitation measurements to interpolate a map of values across a geographical area defined by the user (Bowen et al., 2015). These models use precipitation isotope data from long-term precipitation sampling sites across western North America to interpolate $\delta^{18} \mathrm{O}$ or $\delta \mathrm{D}$ values of summer (April-September) and winter 
(October-March) precipitation using latitude and longitude as input variables (Welker, 2000; IAEA/WMO, 2011; Neff 2014a\&b; Neff 2015a\&b).

\section{Seasonalization of recharge using stable water isotopes}

Past studies in the Basin and Range have shown that it is possible to parse out geographical and temporal sources of recharge using stable isotopic tracers of water (e.g., Simpson et al., 1972; Winograd et al., 1998). Using volume-weighted mean values for $\delta^{18} \mathrm{O}$ and $\delta \mathrm{D}$ of summer and winter precipitation as two endmembers, in addition to mean values for groundwater in a basin, a two-endmember mixing model can be used to determine the percent contribution of summer and winter precipitation to groundwater recharge. Analysis of stable water isotopes in river baseflow and flood flows can further elucidate flow paths and seasonal hydrologic variability in a basin.

Once the precipitation endmember isotopic values are known, it is possible to determine their relative contribution to basin groundwater. This analysis relies on a massbalance two-component mixing model approach to determining the relative contributions of source water with differing isotopic signatures (Genereux and Hooper, 1998). The endmembers are the $\delta^{18} \mathrm{O}$ or $\delta \mathrm{D}$ values of summer and winter precipitation, and they are assumed to be conservative tracers within the basin. The mixing model is solved to determine the fraction of winter and summer precipitation $\left(f_{w}\right.$ and $\left.f_{s}\right)$ :

$$
\begin{gathered}
{\left[\delta^{18} 0\right]_{g w}=f_{w}\left[\delta^{18} 0\right]_{\text {winter precip }}+\left(1-f_{w}\right)\left[\delta^{18} 0\right]_{\text {summer precip }}} \\
f_{w}=\frac{\left[\delta^{18} 0\right]_{g w}-\left[\delta^{18} 0\right]_{\text {summer precip }}}{\left[\delta^{18} 0\right]_{\text {winter precip }}-\left[\delta^{18} 0\right]_{\text {summer precip }}} \\
f_{s}=1-f_{w}
\end{gathered}
$$


There is uncertainty in the fraction of winter recharge arising from the variation of samples used to interpolate the seasonal precipitation isotope values over the study area, as well as in the execution of the interpolation itself, which is a simplified model that ignores topographical effects and seasonal variability. There is additional uncertainty introduced by variation in the groundwater samples used here to determine mean isotopic values of basin groundwater. This uncertainty was quantified by propagating endmember uncertainty through the winter recharge fraction equation for each stable isotope. The equation was solved nine times for each isotope, using various combinations of the mean and standard deviation values of the three end members, producing a suite of eighteen estimates of percent winter recharge (Table 1). The mean and standard deviations of these eighteen solutions is reported for the overall mean, and the nine solutions per isotope are reported as the isotope-specific means.

\section{RESULTS}

\section{Hydroclimatology of the Río San Miguel}

The amount of precipitation available for runoff or recharge for the various subbasins of the Río San Miguel shows more favorable climatologic conditions for recharge in upstream sub-basins (Figure 3). Between basins, the ratio of precipitation to annual potential evapotranspiration (PET) decreases between $1.1 \%$ to $1.6 \%$ with each shift toward the next downstream basin. PET was calculated using the Turc method (RangelMedina et al., in-prep).

Analysis of 30 years of daily streamflow data from CONAGUA's El Cajón gauge located between Rayón and San Miguel de Horcasitas highlights the impact of local climatology on river flows. There is considerable interannual variability in annual streamflow (Figure 4). Years of exceptionally high flows tend to follow years in which 
the El Nino-Southern Oscillation (ENSO) brings heavy precipitation to western North America. In a representative year, the largest streamflows occur during the late summer monsoon season, and are magnitudes greater than baseflow (Figure 5).

Mean monthly streamflow values reflect the seasonality of precipitation in the basin, with the impact of the late summer monsoon and the importance of October tropical cyclones visible in elevated mean monthly totals for those time periods (Figure 6) (Camargo et al., 2008). Finally, the streamflow duration curves for the Río San Miguel exhibit steep slopes characteristic of a basin with highly variable streamflow that derives its flow primarily from quick runoff (Figure 7) (Searcy, 1959). The shallow slopes at the lower end of the flow duration curves indicate the basin has a large amount of storage which maintains baseflow.

\section{Seasonality of recharge}

Stable water isotopic signatures of precipitation, groundwater, and river water tell the story of the geographical location and timing of groundwater recharge (Table 2 and Figure 9). While there is significant variability in the isotopic signatures of surface water, there is less variability in groundwater samples (Figure 9). The mean $\delta^{18} \mathrm{O}$ and $\delta \mathrm{D}$ values of basin groundwater fall along the local meteoric water line (LMWL), which has a slope shallower than the global meteoric water line (GMWL), indicative of an evaporative trend in the basin (Clark and Fritz, 1997). Modeled precipitation $\delta^{18} \mathrm{O}$ and $\delta \mathrm{D}$ values for summer and winter precipitation became lighter with increasing latitude, and an increase was also seen from west to east in winter precipitation (Figure 8). Winter precipitation was more negative than summer precipitation, with basin groundwater values falling between the two (Table 2 and Figure 9). 


\section{Interannual variability in isotopic signatures}

When the stable water isotope data for both groundwater and surface water are examined based on the timing of the samples, greater variability is seen in the summer samples than in the winter and spring samples (Figure 10). Surface water samples from summer 2006 monsoon flooding are the least negative samples from the entire sampling period, whereas surface water samples from summer 2007 monsoon flooding, the very next year, are the most negative samples from the sampling period (Figure 10). The low variability in basin groundwater values indicates that this high interannual variability in precipitation and surface water is dampened by basin recharge processes.

\section{Seasonal contribution of precipitation to recharge}

The $\delta^{18} \mathrm{O}$ and $\delta \mathrm{D}$ values for winter and summer precipitation from the isoscape model and mean basin groundwater from observed samples were used to solve the twoendmember mixing model (Table 1). The percent contribution of winter precipitation to recharge calculated from $\delta^{18} \mathrm{O}$ values is $61 \% \pm 45 \%$ (from $\delta \mathrm{D}$ values: $77 \% \pm 45 \%$ ). The overall mean contribution of winter precipitation to recharge is $69 \% \pm 42 \%$. The dominance of winter precipitation in recharge stands in contrast to the seasonality of precipitation in the basin, which is dominated by summer precipitation from the NAM and tropical cyclones, varying from $60-67 \%$ of total annual precipitation across the basin (Rangel-Medina et al., in-prep).

\section{Water chemistry}

Geographical zones of significant recharge can be identified using geochemical and climatologic data for the San Miguel Basin. Chloride and sulfate concentrations generally increase with distance downriver, as the body of water experiences evaporation (Figures 11 and 12). By considering the ratio of sulfate to chloride in water samples, it is 
possible to identify waters of similar and dissimilar origins (Baillie et al., 2007). In the Río San Miguel Basin, groundwater and surface water samples collected at upland sites exhibited greater variability in $\mathrm{SO}_{4} / \mathrm{Cl}$ ratios, suggesting that a variety of different recharge zones with different source waters contribute to recharge and streamflow in those areas (Figures 13 and 14). The ratio of sulfate to chloride in groundwater samples decreased downstream (Figure 13). The downstream sites of Rayón and San Miguel de Horcasitas exhibit little variability in $\mathrm{SO}_{4} / \mathrm{Cl}$ ratios as $\mathrm{Cl}$ increases (Figure 14). Among the sampling sites, only sites around the town of Rayón had samples that had $\mathrm{SO}_{4} / \mathrm{Cl}$ ratios similar to either upstream or downstream sites. A ternary diagram of major cations in surface water and groundwater samples tells a similar story (Figure 6). There was greater variability in the chemical composition of surface water samples and samples from upland sample sites.

\section{DISCUSSION}

\section{Recharge locations and processes}

Variability of the sulfate to chloride ratio in groundwater and surface water samples decreases downstream (Figures 13 and 14), and variability in major ion chemistry is greater for upstream sites than downstream sites (Figure 15). If only evaporation was affecting the concentration of chloride and sulfate in groundwater and surface water, there would be no change in the ratio of sulfate to chloride over the course of the river. However, there is a pattern of decreasing variability in the sulfate to chloride ratio downstream. This decreasing variability can potentially be explained by several hypotheses: 1) halite dissolution which increases downstream chloride concentrations relative to sulfate; 2) gypsum precipitation, which decreases downstream sulfate concentrations relative to chloride; 3) large subsurface storage below Rayón that 
dampens upstream variability; or 4) mixing of diverse waters above and at Rayón, with little new water entering the system below Rayón.

Halite dissolution is not a likely cause of decreasing variability in major ions downstream. There are no known halite deposits in the San Miguel Basin (CONAGUA, 2008). There are many igneous rocks in the basin that could be a source of sulfate. However, simple modeling using PHREEQC of the evaporation of water with starting ion concentrations similar to groundwater in Cucurpe, close to the headwaters, indicates that these waters do not reach saturation for sulfate. While this does not completely rule out gypsum precipitation as a driver of decreasing and homogenizing sulfate to chloride ratios, sulfur isotope data would be necessary to investigate potential markers of sulfur transformation (Gu et al., 2008).

The influence of a large reservoir of stored groundwater below Rayón is unlikely to cause decreasing major ion variability downstream. The sharp decrease in variability in sulfate to chloride ratios between Rayón and San Miguel de Horcasitas could be an effect of large storage in the lower two sub-basins, with surface areas of $976.4 \mathrm{~km}^{2}$ and 1,454.36 km² for the Rayón and San Miguel de Horcasitas sub-basins, respectively. However, water table depths were the greatest in this sub-basin, reaching over $100 \mathrm{~m}$ in some locations (Rangel-Medina et al., in-prep). Given that even flood flows at San Miguel de Horcasitas experienced decreased variability and a narrow range similar to groundwater samples from that location (Figure 13), the homogenization of waters with respect to sulfate to chloride ratios must occur prior to the arrival of waters in the San Miguel de Horcasitas sub-basin, likely coinciding with perennial upwelling at the bedrock high at Rayón. 
Having ruled out halite dissolution, gypsum precipitation, and a large reservoir effect, the remaining explanation for downstream trends in sulfate to chloride ratios is the integration of diverse waters above and at Rayón. The hypothesis that little new water enters the basin below Rayón is supported by the water balance study conducted for the basin, which found that recharge normalized by sub-basin area in the San Miguel de Horcasitas sub-basin was $68 \%$ less than in the Rayón-Opodepe sub-basin (RangelMedina et al., in-prep).

But where does the mixing that leads to the downstream integration of anion concentrations occur? Calcium ion concentrations as a function of distance downstream take on a funnel shape, with variance decreasing downstream (Figure 16). In basins where deep groundwater flow plays a significant role in stream generation, cation concentrations would be expected in increase with drainage size (or distance downstream) (Uchida et al., 2005; Frisbee et al., 2011). In the San Miguel Basin, cation concentrations decrease in value and variance. This finding, together with the characterization of the basin derived from the streamflow generation curves, suggests that groundwaters and surface waters are derived from mixing of recharge following shallower, shorter flow paths as well as deeper groundwater as far as Rayón and the El Cajón stream gauge.

This finding indicates that the major inputs of new water (recharge) occur from the headwaters regions down to Rayón, with negligible new water entering the basin downstream of Rayón. New water recharges in the upland catchments in the mountain block and along the mountain front before mixing in the subsurface or riparian zone. Past studies have found that winter recharge is generally dominated by mountain-system 
processes, so this finding is supported by the determination of a winter-dominated recharge regime for the basin (Winograd et al., 1998; Wahi et al., 2008).

Hydrogeological characterization of the basin shows that bedrock intrusions between the sub-basins of the Río San Miguel cause hydrological separation of the basins, with interbasin flow occurring in or near the stream course (CONAGUA, 2008). Current understanding of the hydrogeology of the system indicates sub-basin aquifers connected to each other by perennial river reaches (Figure 17). Recharge occurs primarily in the uppermost sub-basins, some new recharge also occurs in the Rayón sub-basin, and water flows between basins through narrow channels and riparian aquifers. By the time waters enter the San Miguel de Horcasitas sub-basin, they are well-mixed and early differences in ion composition are no longer observed.

\section{Stream-aquifer interactions}

Storm flows in the basin are characterized by quick runoff, which can be seen both in 26 years of flow duration curves for the basin, and in the extreme variation in the isotopic composition of flood waters between summer 2006 and 2007 (Figures 4 and 10). During large monsoon and tropical cyclone flood events, the river is made up primarily of event water. This event water may come from direct surface runoff, or it may come from recent bank storage, as there is increasing evidence that near-stream recharge to shallow riparian aquifers can support riparian vegetation in times of reduced baseflow (Baillie et al., 2007; Simpson et al., 2013). During dry periods, the river is composed primarily of baseflow discharging from the aquifer whose isotopic composition is similar to mean basin groundwater.

The variation in isotopic composition between those monsoon flood flows in 2006 and 2007 might be explained by differences in precipitation source or storm size for those 
storms. NAM systems have been shown to have three distinct sources of moisture with differing isotopic signatures: the eastern equatorial Pacific, the Gulf of Mexico, and finally re-evaporated terrestrial water from Mexico (Hu and Dominguez, 2015). The less negative $\delta^{18} \mathrm{O}$ and $\delta \mathrm{D}$ values of the summer 2006 flood flows might be attributed to a monsoon event whose water was sourced primarily from the Gulf of Mexico.

Alternatively, there has been observed an amount effect in stable isotope values of precipitation, with larger precipitation events tending to have more negative $\delta^{18} \mathrm{O}$ and $\delta \mathrm{D}$ values (Dansgaard, 1964). The more negative 2007 flood flow could be the result of a storm that deposited more precipitation in the basin. Examination of streamflow data from the El Cajon gauge reveals that flood flows in July 2007 were about double the flow in July 2006, supporting the amount effect hypothesis. The amount effect might have an impact also on the seasonal precipitation isotopic endmembers, with larger storms causing the endmembers to be more negative and storm size causing interannual variability in the isotopic composition of summer and winter precipitation.

\section{Recharge seasonality}

In comparison to more northern basins in the Basin and Range Province, the San Miguel Basin has a greater influence of summer precipitation on recharge, with $69 \% \pm$ $42 \%$ winter recharge. The Spring Mountains in Nevada were found to have groundwater composed of about $80 \%$ winter precipitation, with the Verde Basin in north central Arizona is estimated to receive greater than $90 \%$ of its recharge from winter precipitation (Winograd et al., 1998; Blasch and Bryson, 2007). However, the nearby Upper San Pedro Basin, only some $200 \mathrm{~km}$ away from the San Miguel Basin, was found to have a winter recharge fraction very similar to the San Miguel: $65 \% \pm 25 \%$ (Wahi et al., 2008). 
This difference between the northern basins and the southern basins reflects the greater influence of NAM precipitation in the south. The seasonality of recharge in the NAM zone basins indicates that summer precipitation is converted into recharge at a less efficient rate than winter precipitation. Still, all these basins are dominated by winter recharge. Winter recharge in other Basin and Range aquifers have been shown to be dominated by mountain-system recharge processes occurring in the mountain-block and mountain-front areas of the basins (Simpson et al., 1972; Thiros and Manning, 2004; Wilson and Guan, 2004; Druhan et al., 2008; Wahi et al., 2008). Evidence for greater recharge in the upland sub-basins of the San Miguel Basin indicates that mountainsystem recharge processes similarly dominate recharge in this basin.

The greatest challenge in generating an estimate of recharge seasonality in these Basin and Range systems is quantifying and addressing the many sources of uncertainty in endmember $\delta^{18} \mathrm{O}$ and $\delta \mathrm{D}$ values. Elevation has been shown to have an impact on $\delta^{18} \mathrm{O}$ and $\delta \mathrm{D}$ values, with a gradient of $-1.6 \%$ per $1000 \mathrm{~m}$ rise determined empirically for $\delta^{18} \mathrm{O}$ in the Upper San Pedro Basin and -11\%o per 1000 m rise determined empirically for $\delta \mathrm{D}$ in the Tucson Basin (Wright, 2001). The impact of elevation was taken into account here by adding $1.6 \%$ o to the error of the $\delta^{18} \mathrm{O}$ and $11 \%$ for the $\delta \mathrm{D}$ seasonal precipitation endmembers, assuming that the mean value as calculated from the models represented precipitation in the center of the basin, and the relief of the basin is approximately 2000 m.

Because the precipitation endmembers were modeled based on latitude only, there are several sources of uncertainty that were not quantitatively incorporated into the seasonal recharge calculation. In precipitation samples, there can be significant inter- and 
intra-annual variation in $\delta^{18} \mathrm{O}$ and $\delta \mathrm{D}$ values for samples taken at the same location. In Tucson, Arizona, $\delta^{18} \mathrm{O}$ of summer precipitation samples for the period 1981-2008 ranged from $-17 \%$ o to $17 \%$ o (Wright, 2001). Because these precipitation values were modeled using empirical data from stations far afield from the basin, the inter- and intra-annual variability in this basin are represented by the error in the models themselves. For summer $\delta^{18} \mathrm{O}$ values, the mean squared error of the model was 4.63; for winter $\delta^{18} \mathrm{O}$ values, 11.32; for summer $\delta \mathrm{D}$ values, 295.71; and for winter $\delta \mathrm{D}$ values, 724.06. The model error was a magnitude greater for the summer values, representing the great variability in the isotopic composition of NAM precipitation as demonstrated in flood flow samples in this study, and examined systematically by Hu and Dominguez (2015). Another source of uncertainty arises from the use of mean basin groundwater as an endmember. Groundwaters in the Basin and Range that travel long flow paths through bedrock can have very long residence times, raising the question of whether climate and its attendent $\delta^{18} \mathrm{O}$ and $\delta \mathrm{D}$ values of precipitation have been stationary over the period in which waters now present in the basin recharge. The $\delta^{18} \mathrm{O}$ of calcite record at Devils Hole in southern Nevada indicates that prior to $17.5 \mathrm{ka}$, the climate of the western U.S. was warmer and wetter (Winograd et al., 2006). This finding is corroborated from studies of paleolake shores in the modern day Great Basin desert (Lyle et al., 2012). Meanwhile, paleo-vegetation recorded in packrat middens in the Mojave Desert indicate that between 6,800 and 5,060 years ago, the region was drier than the present (Spaulding 1991). Waters up to 35 ka have been identified in the nearby Middle San Pedro Basin, a period which encompasses those climate shifts (Hopkins et al., 2014). While climate variation over the period of recharge of modern groundwater does introduce uncertainty into the 
use of $\delta^{18} \mathrm{O}$ and $\delta \mathrm{D}$ values of precipitation as endmembers, the analysis conducted here remains useful.

\section{CONCLUSIONS}

Although the Río San Miguel Basin is dominated by summer precipitation, the majority of groundwater recharge in the basin occurs as a result of winter precipitation $(69 \% \pm 42 \%)$. This result can be explained by the dominance of mountain-system recharge processes in the Basin and Range Province, and the high runoff coefficients of monsoon storms. The San Miguel shares this shift between the timing of precipitation and timing of recharge with other basins in the southern Basin and Range, such as the Upper San Pedro Basin, which receives a similar average fraction of its recharge from summer precipitation as does the San Miguel Basin. Both basins receive more recharge from summer precipitation than do more northern basins. This difference is likely due to the influence of the NAM on the climatology of the southern basins.

\section{ACKNOWLEDGMENTS}

This paper was developed under STAR Fellowship Assistance Agreement no. FP91749101-0 awarded by the U.S. Environmental Protection Agency (EPA). It has not been formally reviewed by EPA. The views expressed in this paper are solely those of Kirstin L. Neff, and EPA does not endorse any products or commercial services mentioned in this paper. This work was supported in part by a NSF Dynamics of Coupled Human-Natural Systems grant (DEB-1010495).

Special thanks to Ryan Lee for his help in sample collection, and Chris Scott for his leadership on the Río San Miguel/Upper San Pedro River CNH project. Thanks also to Paloma Castro Noriega, David Chan, Moira Hough, Lily House-Peters, America Lutz, 
and Aloah Pope for their collaboration throughout the development and implementation of this project. 


\section{REFERENCES}

Abdulaziz AM, Hurtado JM, Faid A. 2012. Hydrogeological characterization of Gold Valley: an investigation of precipitation recharge in an intermountain basin in the Death Valley region, California, USA. Hydrogeology Journal 20(4): 701-718.

Ajami H, Meixner T, Dominguez F, Hogan JF, Maddock III T. 2012. Seasonalizing mountain system recharge in semi-arid basins--climate change impacts. Ground Water 50(4): 585-597.

Anderson K, Nelson S, Mayo A, Tingey D. 2006. Interbasin flow revisited: the contribution of local recharge to high-discharge springs, Death Valley, CA. Journal of Hydrology 323: 276-302. DOI:10.1016/j.jhydrol.2005.09.004.

Baillie MN, Hogan JF, Ekwurzel B, Wahi AK, Eastoe CJ. 2007. Quantifying water sources to a semi-arid riparian ecosystem, San Pedro River, Arizona. Journal of Geophysical Research 112, G03S02, DOI:10.1029/2006JG000263.

Blasch KW, Bryson JR. 2007. Distinguishing sources of ground water recharge by using $\delta \mathrm{D}$ and $\delta^{18}$ O. Ground Water 45(3): 293-308. DOI: 10.1111/j.1745-6584.2006.00289.x.

Bowen GJ, West JB, Miller CC, Zhao L, Zhang T. 2015. IsoMAP: Isoscapes Modeling, Analysis and Prediction (version 1.0). The IsoMAP Project. http://isomap.org.

Camargo SJ, Robertson AW, Barnston AG, Ghil M. 2008. Clustering of eastern North Pacific tropical cyclone tracks: ENSO and MJO effects. Geochemistry Geophysics Geosystems 9(6). 23pp. doi:10.1029/2007GC001861.

Castro CL, Chang H, Dominguez F, Carillo C, Schemm J, Juang HH. 2012. Can a regional climate model improve the ability to forecast the North American Monsoon? Journal of Climate 25: 8212-8237.

Comisión Nacional del Agua (CONAGUA). 2008. Disponibilidad media anual de agua subterránea: 2625 Río San Miguel. Federal government of Mexico, August 28, 2008. 44pp.

Clark ID, Fritz P. 1997. Environmental Isotopes in Hydrogeology. CRC Press: NewYork; 328.

Craig H. 1957. Isotopic standards for carbon and oxygen and correction factors for massspectrometric analysis of carbon dioxide. Geochim Cosmochim Acta 12: 133-149.

Craig H. 1961a. Variations in meteoric waters. Science 133(3465): 1702-1703.

Craig H. 1961b. Standard for reporting concentrations of deuterium and oxygen-18 in natural waters. Science 133(3467): 1833-1834. 
de Vries JJ, Simmers I. 2002. Groundwater recharge: an overview of processes and challenges. Hydrogeology Journal 10: 5-17.

Dickinson JE, Hanson TR, Ferré TPA, Leake SA. 2004. Inferring time-varying recharge from inverse analysis of long-term water levels. Water Resources Research 40, W07403, DOI:10.1029/2003WR002650.

Dominguez F, Rivera E, Lettenmaier DP, Castro CL. 2012. Changes in winter precipitation extremes for the western United States under a warmer climate as simulated by regional climate models, Geophysical Research Letters. DOI:

10.1029/2011GL050762.

Dominguez F, Villegas JC, Breshears DD. 2009. Spatial extent of the North American Monsoon: Increased crossregional linkages via atmospheric pathways. Geophysical Research Letters 36: L07401. DOI:10.1029/2008GL037012.

Druhan JL, Hogan JF, Eastoe CJ, Hibbs BJ, Hutchison WR. 2008. Hydrogeologic controls on groundwater recharge and salinization: a geochemical analysis of the northern Hueco Bolson aquifer, Texas, USA. Hydrogeology Journal 16: 281-296. DOI: DOI 10.1007/s10040-007-0222-9.

Eastoe CJ, Gu A, Long A. 2004. The origins, ages and flow paths of groundwater in Tucson Basin: results of a study of multiple isotope systems. In Groundwater Recharge in a Desert Environment: the Southwestern United States, edited by Hogan JF, Phillips FM, Scanlon BR. American Geophysical Union: Washington, D.C.: 217-234.

Eastoe CJ, Hibbs BJ, Olivas A, Hogan JF, Hawley J, Hutchison WR. 2008. Isotopes in the Hueco Bolson aquifer, Texas (USA) and Chihuahua (Mexico): local and general implications for recharge sources in alluvial basins. Hydrogeology Journal 16(4): 737747.

Frisbee MD, Phillips FM, Campbell AR, Liu F, Sanchez SA. 2011. Streamflow generation in a large, alpine watershed in the southern Rocky Mountains of Colorado: Is streamflow generation simply the aggregation of hillslope runoff responses? Water Resources Research 47, W06512, doi: 10.1029/2010WR009391.

Gehre M, Hoefling R, Kowski P, Struach G. 1996. Sample preparation device for quantitative hydrogen isotope analysis using chromium metal. Analytical Chemistry 68: 4414-4417.

Genereux DP, Hooper RP. 1998. Oxygen and hydrogen isotopes in rainfall-runoff studies, in Isotope Tracers in Catchment Hydrology, eds. Kendall C, McDonnell J, chap. 10, pp. 319-346, Elsevier Sci., Amsterdam.

Gonfiantini R. 1978. Standards for stable isotope measurements in natural compounds. Nature 271: 534-536. 
Grimm NB, Chacón A, Dahm CN, Hostetler SW, Lind OT, Starkweather PL, Wurtsbaugh WW. 1997. Sensitivity of aquatic ecosystems to climatic and anthropogenic changes: the Basin and Range, American Southwest and Mexico. Hydrological Processes 11: $1023-1041$.

Gu A, Gray F, Eastoe CJ, Norman LM, Duarte O, Long A. 2008. Tracing water input to base flow using sulfate (S, O) isotopes. Ground Water 46(3): 502-509. doi: 10.1111/j.1745-6584.2008.00437.x.

Hopkins CB, McIntosh JC, Eastoe C, Dickinson JE, Meixner T. 2014. Evaluation of the importance of clay confining units on groundwater flow in alluvial basins using solute and isotope tracers: the case of Middle San Pedro Basin in southeastern Arizona (USA). Hydrogeology Journal 22: 829-849. doi: 10.1007/s10040-013-1090-0.

Hu H, Dominguez F. 2015. Evaluation of oceanic and terrestrial sources of moisture for the North American Monsoon using numerical models and precipitation stable isotopes. Journal of Hydrometeorology 16: 19-35. DOI: 10.1175/JHM-D-14-0073.1.

IAEA/WMO. 2011. Global Network of Isotopes in Precipitation. The GNIP Database. Accessible at: http://www.iaea.org/water.

Izbicki JA, Radyk J, Michel RL. 2000. Water movement through a thick unsaturated zone underlying an intermittent stream in the western Mojave Desert, southern California. Journal of Hydrology 238: 194-217.

Lyle M, Heusser L, Ravelo C, Yamamoto M, Barron J, Diffenbaugh NS, Herbert T, Andreasen D. 2012. Out of the tropics: the Pacific, Great Basin lakes, and late Pleistocene water cycle in the western United States. Science 337: 1629-1633.

McPhee J. 1980. Basin and Range. New York, NY: Farrar, Straus, and Giroux. 216pp.

Meixner T, Manning AH, Stonestrom D, Ajami H, Allen DM, Blasch K, Brookfield A, Castro CL, Clark JF, Gochis D, Flint A, Neff KL, Niraula R, Rodell M, Scanlon B, Singha K, Walvoord M. Implications of Projected Climate Change for Groundwater Recharge in the Western United States. Environmental Research Letters (in-review).

Méndez-Barroso LA, Vivoni ER, Robles-Morua A, Mascaro G, Yépez EA, Rodríguez JC, Watts CJ, Garatuza-Payán J, Saíz-Hernández JA. 2014. A modeling approach reveals differences in evapotranspiration and its partitioning in two semi-arid ecosystems in Northwest Mexico. Water Resources Research 50: 3229-3252, doi: 10.1002/2013WR14838.

Méndez-Barroso LA, Vivoni ER, Watts CJ, Rodríguez JC. 2009. Seasonal and interannual relations between precipitation, surface soil moisture and vegetation dynamics in the North American monsoon region. Journal of Hydrology 377: 59-70.

Neff KL. 2014a. IsoMAP job 44200, Isoscapes Modeling, Analysis and Prediction (version 1.0). The IsoMAP Project. http://isomap.org. 
Neff KL. 2014b. IsoMAP job 44201, Isoscapes Modeling, Analysis and Prediction (version 1.0). The IsoMAP Project. http://isomap.org.

Neff KL. 2015a. IsoMAP job 46708, Isoscapes Modeling, Analysis and Prediction (version 1.0). The IsoMAP Project. http://isomap.org.

Neff KL. 2015b. IsoMAP job 46709, Isoscapes Modeling, Analysis and Prediction (version 1.0). The IsoMAP Project. http://isomap.org.

Rangel-Medina MM, Taylor A, Pineda C, Grijalva I, Meixner T, Neff KL. Variable rates of recharge and hydrogeologic resilience in the intermountain Río San Miguel Basin, Sonora, Mexico (in-prep).

Rose TP, Kersting AB, Harris LJ, Hudson GB, Smith DK, Williams RW, Loewen DR, Nelson EJ, Allen PG, Ryerson FJ, Pawloski GA, Laue CA, Moran JE. 2003. Stable Isotope Investigation of Precipitation and Recharge Processes in Central Nevada. In Hydrologic Resources Management Program and Undeground Test Area Project, 2001 2002 Progress Report. 113-134.

Searcy JK. 1959. Flow Duration Curves, in Manual of hydrology: part 2. low-flow techniques. USGS Water Supply Paper 1542-A.

Simpson ES, Thorud DB, Friedman I. 1972. Distinguishing seasonal recharge to groundwater by deuterium analysis in southern Arizona. In World Water Balance, Proceedings of the 1970 Reading Symposium, International Association of Scientific Hydrology. UNESCO-WMO; 623-633.

Simpson SC, Meixner T, Hogan JF. 2013. The role of flood size and duration on streamflow and riparian groundwater composition in a semi-arid basin. Journal of Hydrology 488: 126-135.DOI: 10.1016/j.jhydrol.2013.02.049.

Spaulding WG. 1991. A middle Holocene vegetation record from the Mojave Desert of North America and its paleoclimatic significance. Quaternary Research 35: 427-437.

Thiros SA, Manning AH. 2004. Quality and sources of ground water used for public supply in Salt Lake Valley, Salt Lake County, Utah, 2001. U.S. Geological Survey Water Resources Investigation Report, 03-4325; 95.

Uchida T, Asano Y, Onda Y, Miyata S. 2005. Are headwaters just the sum of hillslopes? Hydrological Processes 19: 3251-3261. doi: 10.1002/hp.6004.

Wahi AK, Hogan JF, Ekwurzel B, Baillie MN, Eastoe CJ. 2008. Geochemical quantification of semi-arid mountain recharge. Ground Water 46(3): 414-425.

Welker JM. 2000. Isotopic $\left(\delta^{18} \mathrm{O}\right)$ characteristics of weekly precipitation collected across the USA: An initial analysis with application to water source studies. Hydrological Processes 14: 1449-1464. 
Wilson JL, Guan H. 2004. Mountain-block hydrology and mountain-front recharge. In Groundwater Recharge in a Desert Environment: the Southwestern United States, edited by J.F. Hogan, F.M. Phillips, and B.R. Scanlon, American Geophysical Union: Washington D.C.; 113-137.

Winograd, IJ, Landwehr JM, Coplen TB, Sharp WD, Riggs AC, Ludwig KR, Kolesar PT. 2006. Devils Hole, Nevada, $\delta^{18} \mathrm{O}$ record extended to the mid-Holocene, Quarternary Research 66: 202-212.

Winograd IJ, Riggs AC, Coplen TB. 1998. The relative contributions of summer and cool-season precipitation to groundwater recharge, Spring Mountains, Nevada, USA. Hydrogeology Journal 6(1): 77-93.

Wright WE. 2001. $\delta \mathrm{D}$ and $\delta^{18} \mathrm{O}$ in mixed conifer systems in the U.S. Southwest: The potential of $\mathrm{d} 18 \mathrm{O}$ in Pinus Ponderosa tree rings as a natural environmental recorder. Ph.D. thesis, Department of Geosciences, University of Arizona, Tucson, Arizona. 


\section{TABLES}

Table 1. Suite of nine solutions applied to each set of endmembers (both $\delta^{18} O$ and $\delta D$ ) to determine the isotopespecific and overall estimates of fraction winter recharge.

\begin{tabular}{|c|c|c|c|}
\hline \multicolumn{1}{|c|}{ Delta } & $\overline{\boldsymbol{\delta}}_{\boldsymbol{g} \boldsymbol{w}}$ & $\overline{\boldsymbol{\delta}}_{\boldsymbol{g} \boldsymbol{w}}+\boldsymbol{\sigma}$ & $\overline{\boldsymbol{\delta}}_{\boldsymbol{g} \boldsymbol{w}}-\boldsymbol{\sigma}$ \\
\hline$\overline{\boldsymbol{\delta}}_{\boldsymbol{P}}$ & $f_{w}=\frac{\left(g w-P_{s}\right)}{\left(P_{w}-P_{s}\right)}$ & $f_{w}=\frac{\left((g w+\sigma)-P_{s}\right)}{\left(P_{w}-P_{s}\right)}$ & $f_{w}=\frac{\left((g w-\sigma)-P_{s}\right)}{\left(P_{w}-P_{s}\right)}$ \\
\hline$\overline{\boldsymbol{\delta}}_{\boldsymbol{P}}+\boldsymbol{\sigma}$ & $f_{w}=\frac{\left(g w-\left(P_{s}+\sigma\right)\right)}{\left(\left(P_{w}+\sigma\right)-\left(P_{s}+\sigma\right)\right)}$ & $f_{w}=\frac{\left((g w+\sigma)-\left(P_{s}+\sigma\right)\right)}{\left(\left(P_{w}+\sigma\right)-\left(P_{s}+\sigma\right)\right)}$ & $f_{w}=\frac{\left((g w-\sigma)-\left(P_{s}+\sigma\right)\right)}{\left(\left(P_{w}+\sigma\right)-\left(P_{s}+\sigma\right)\right)}$ \\
\hline$\overline{\boldsymbol{\delta}}_{\boldsymbol{P}}-\boldsymbol{\sigma}$ & $f_{w}=\frac{\left(g w-\left(P_{s}-\sigma\right)\right)}{\left(\left(P_{w}-\sigma\right)-\left(P_{s}-\sigma\right)\right)}$ & $f_{w}=\frac{\left((g w+\sigma)-\left(P_{s}-\sigma\right)\right)}{\left(\left(P_{w}-\sigma\right)-\left(P_{s}-\sigma\right)\right)}$ & $f_{w}=\frac{\left((g w-\sigma)-\left(P_{s}-\sigma\right)\right)}{\left(\left(P_{w}-\sigma\right)-\left(P_{s}-\sigma\right)\right)}$ \\
\hline
\end{tabular}

Table 2. Mean $\delta^{18} \mathrm{O}$ and $\delta \mathrm{D}$ values of summer and winter precipitation and basin groundwater, and percent contribution of seasonal precipitation to recharge as determined using a two-endmember mixing model.

\begin{tabular}{|l|c|c|}
\multicolumn{1}{c}{ Sample } & $\begin{array}{c}\text { Mean } \boldsymbol{\delta}^{\mathbf{1 8}} \mathbf{O} \\
(\mathbf{\%} \text { VSMOW) }\end{array}$ & $\begin{array}{c}\text { Mean } \mathbf{\delta D} \\
(\mathbf{\%} \text { VSMOW) }\end{array}$ \\
\hline Summer precipitation & $-4.16 \pm 1.99$ & $-25.7 \pm 3.0$ \\
\hline Winter precipitation & $-7.81 \pm 2.04$ & $-51.2 \pm 3.6$ \\
\hline Groundwater & $-6.38 \pm 0.26$ & $-45.1 \pm 1.3$ \\
\hline
\end{tabular}




\section{FIGURES}

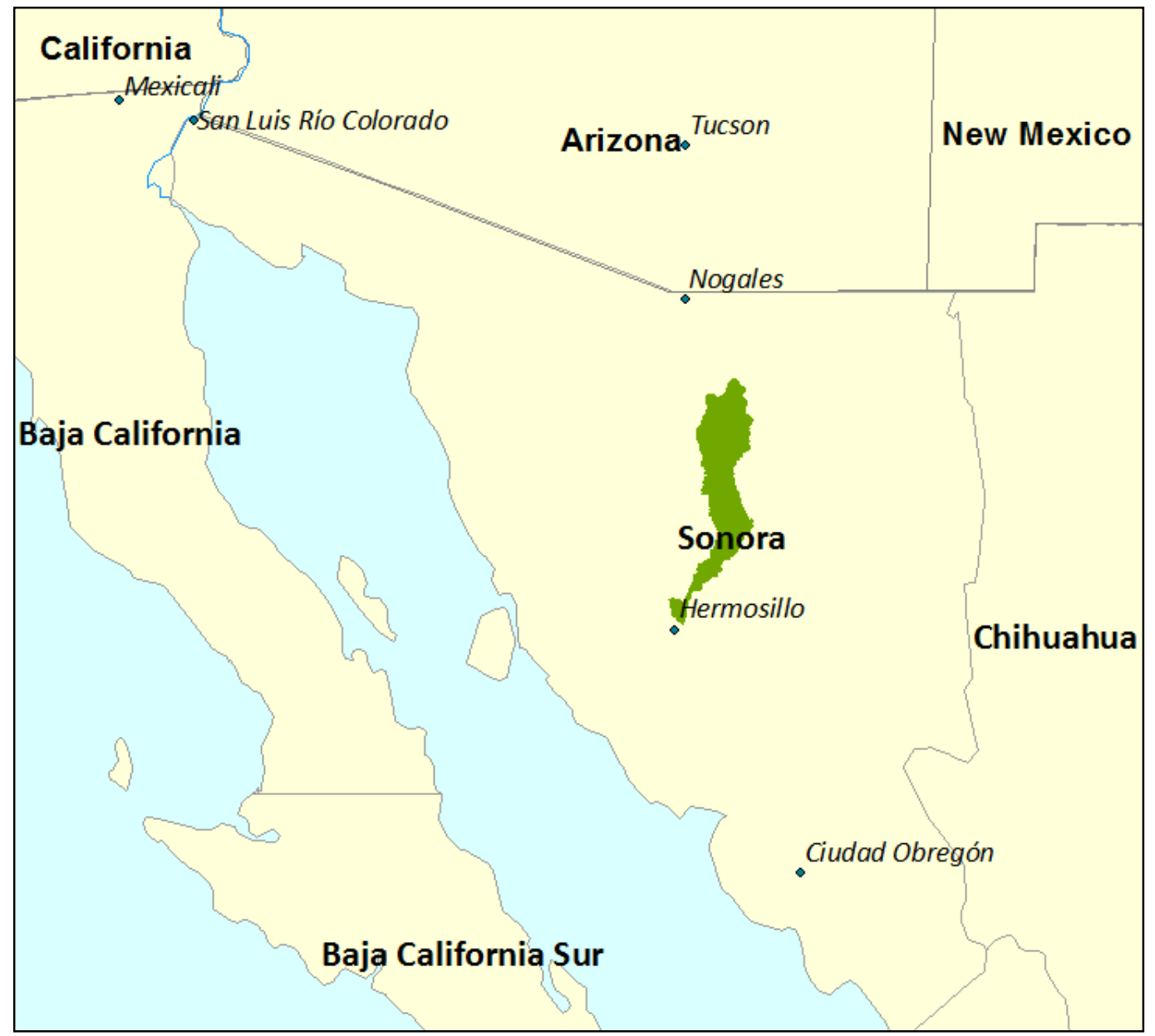

Figure 1. Location of Río San Miguel Basin 


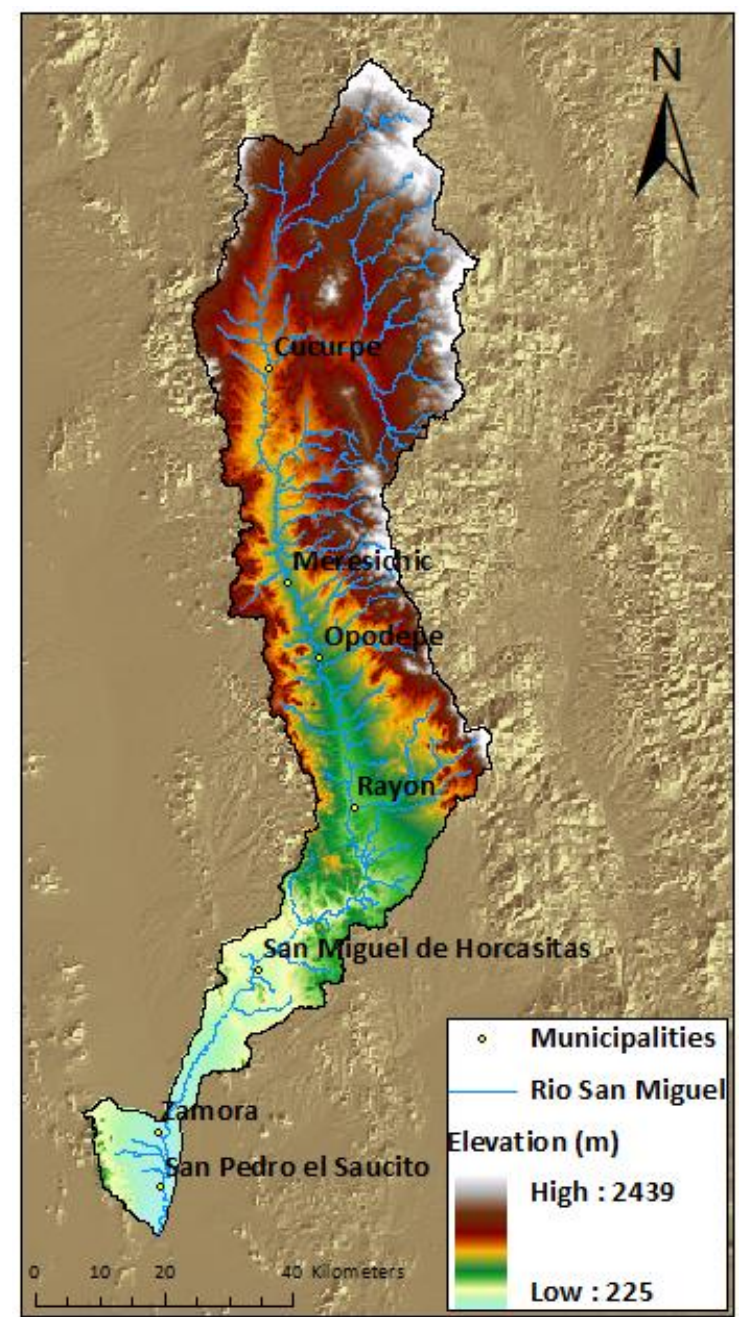

Figure 2. Basin elevation and municipalities

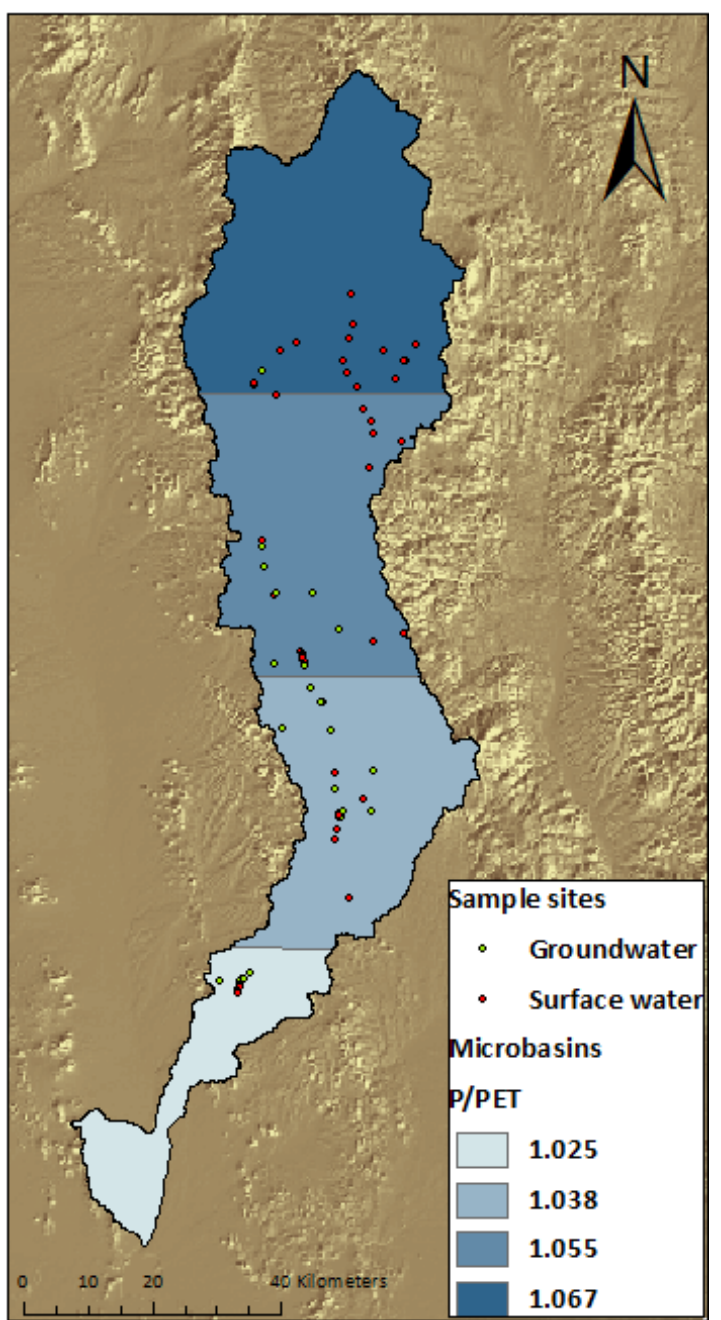

Figure 3. Sample sites and P/PET of micro basins 


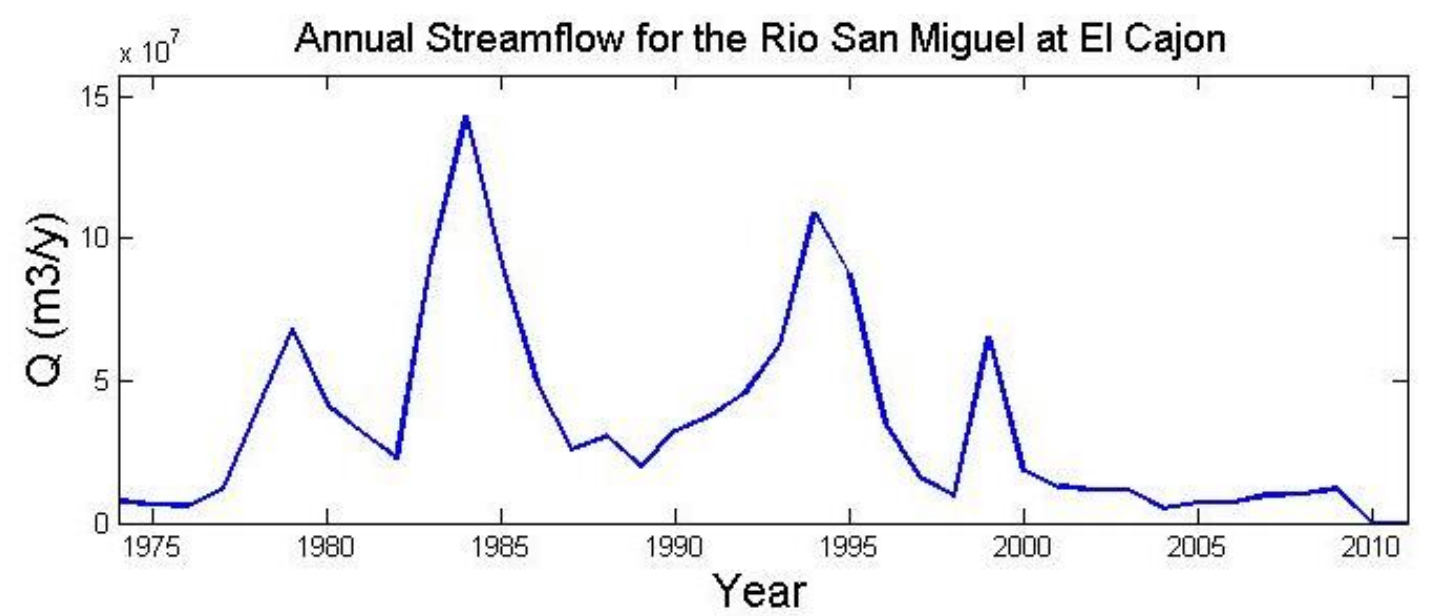

Figure 4. Annual streamflow of the Río San Miguel has varied in the past, with greatest streamflow occurring in conjunction with El Nino events.

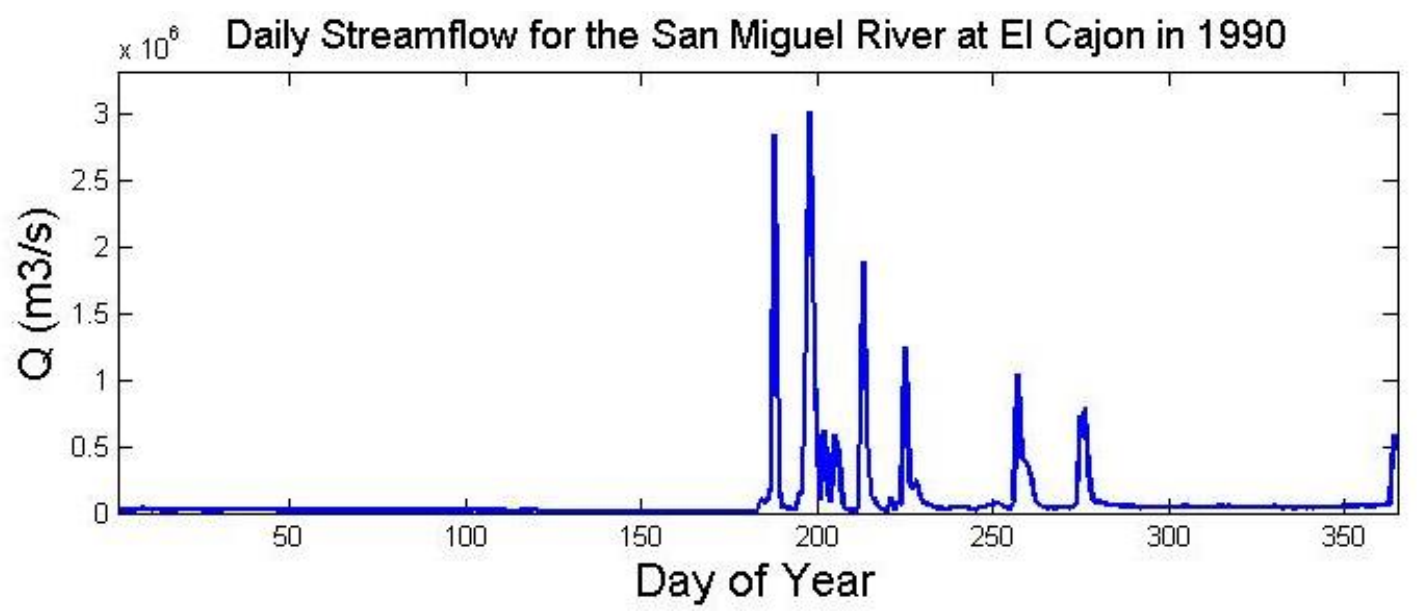

Figure 5. In the course of a year, the Río San Miguel experiences large stormflows in the late summer months due to monsoon storms. Baseflow at the El Cajón gauge is generally around $10,000 \mathrm{~m}^{3} / \mathrm{s}$.

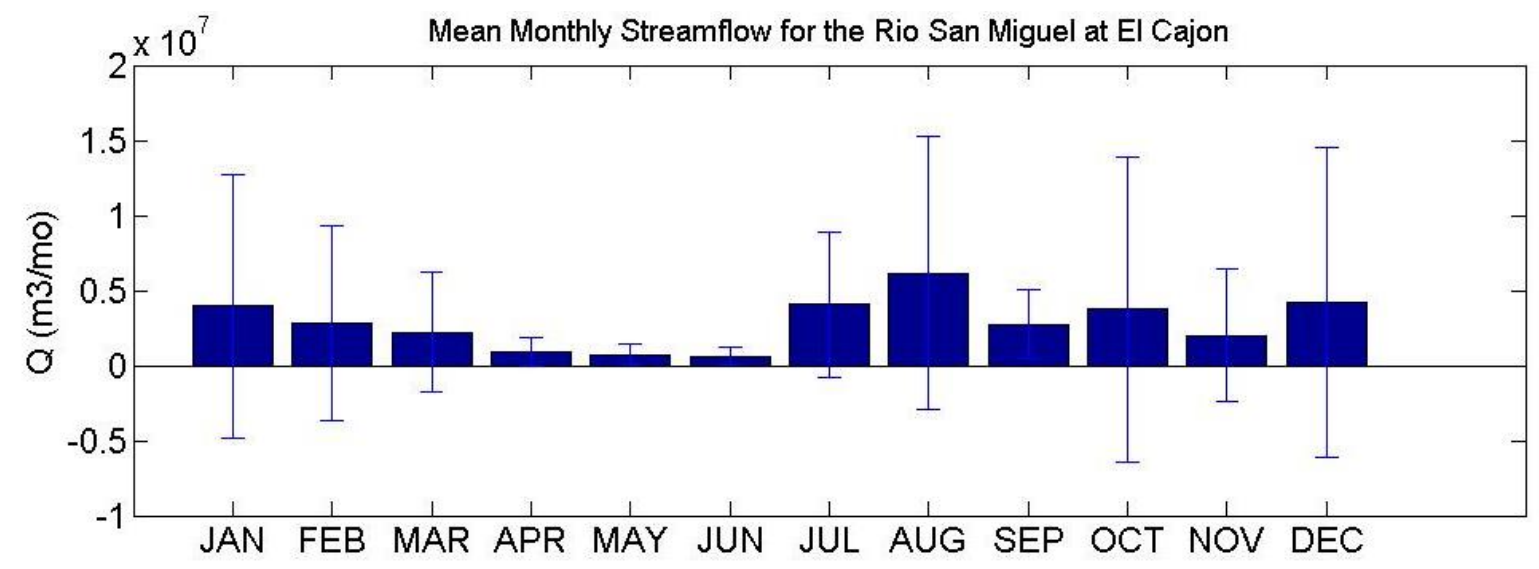

Figure 6. Mean monthly streamflows in exhibit the bimodal precipitation regime of monsoonal summer storms and winter frontal storms. A spring snowmelt peak seen elsewhere in the Basin and Range is absent. 


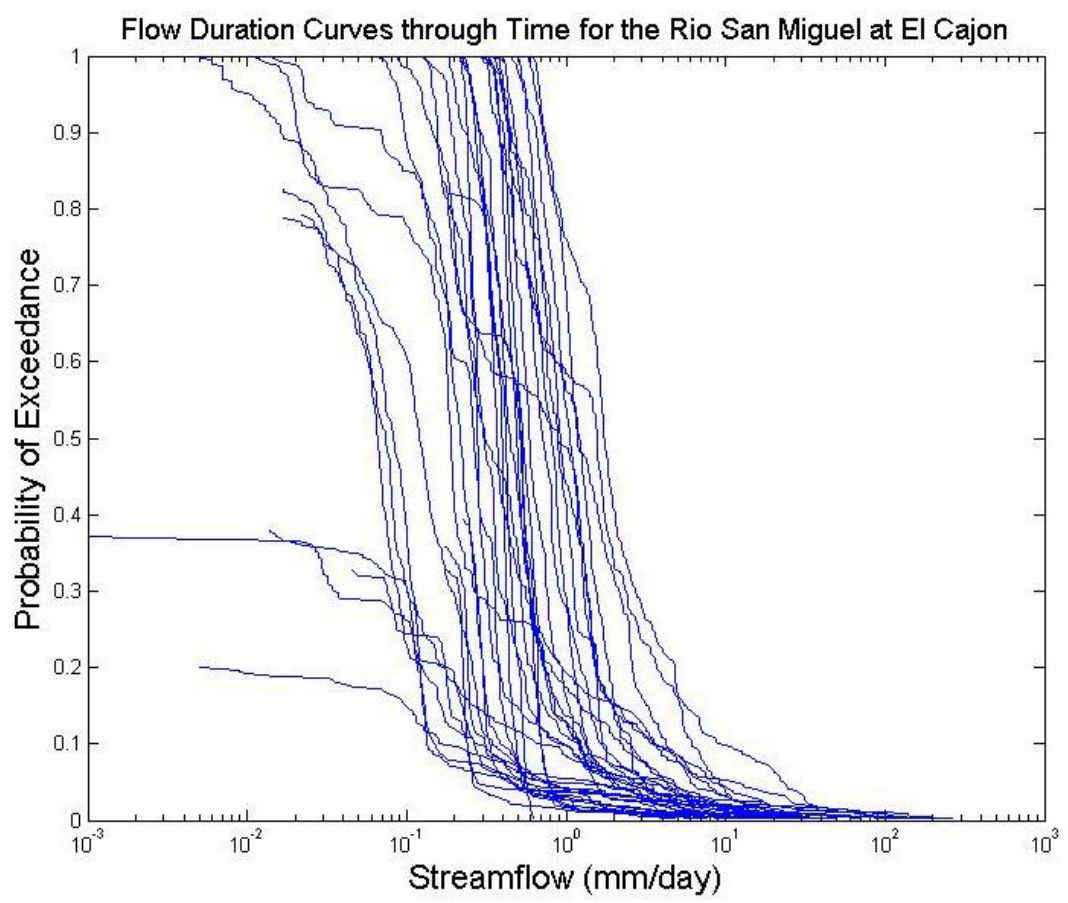

Figure 7. Streamflow duration curves in the Río San vary through time with some years being particularly dry (maximum probabilities of exceedance below 0.4 ).
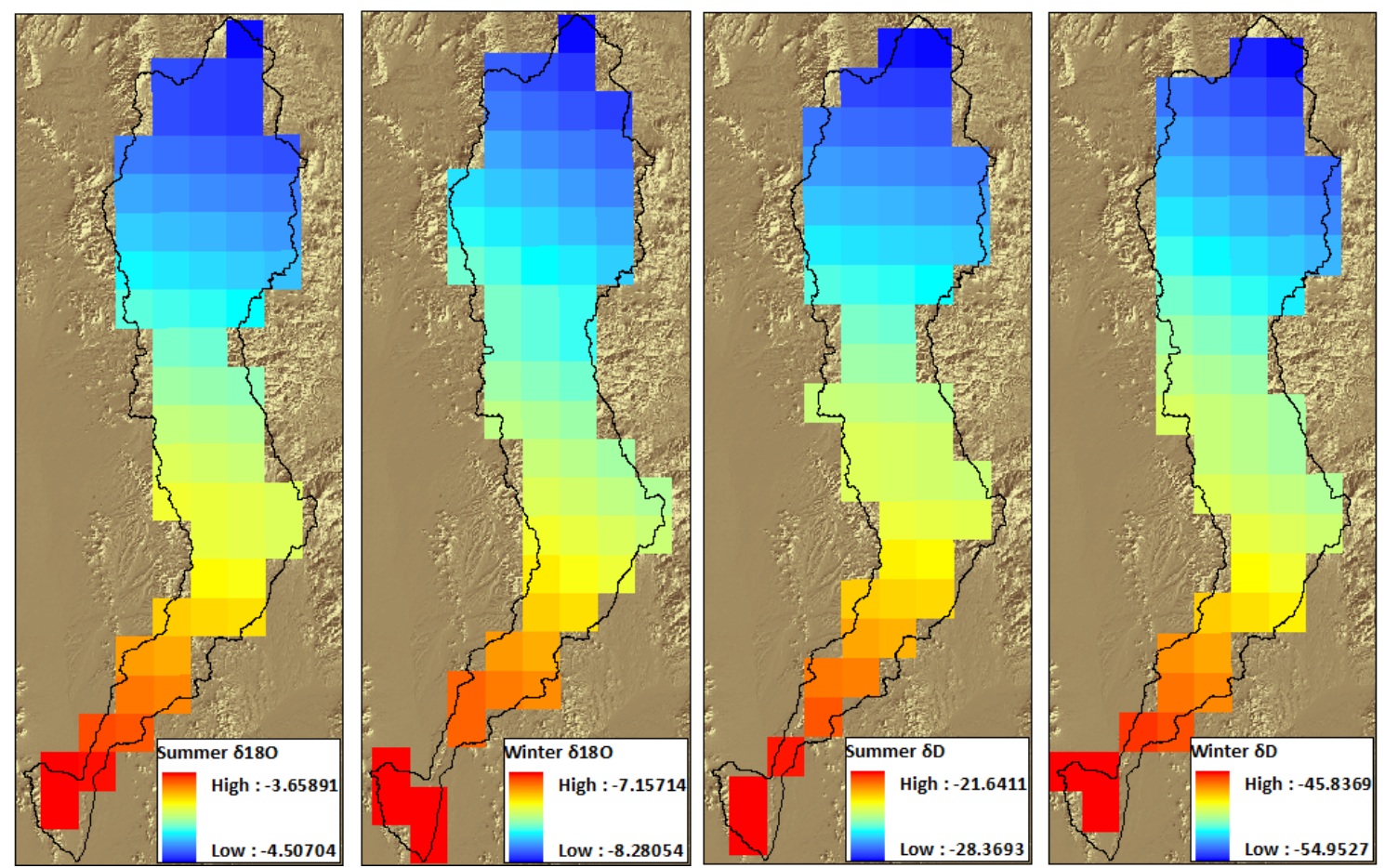

Figure 8. Modeled values of $\delta^{18} \mathrm{O}$ and $\delta \mathrm{D}$ in summer and winter precipitation created from existing long-term datasets using the IsoMAP program and based on latitude and longitude. 


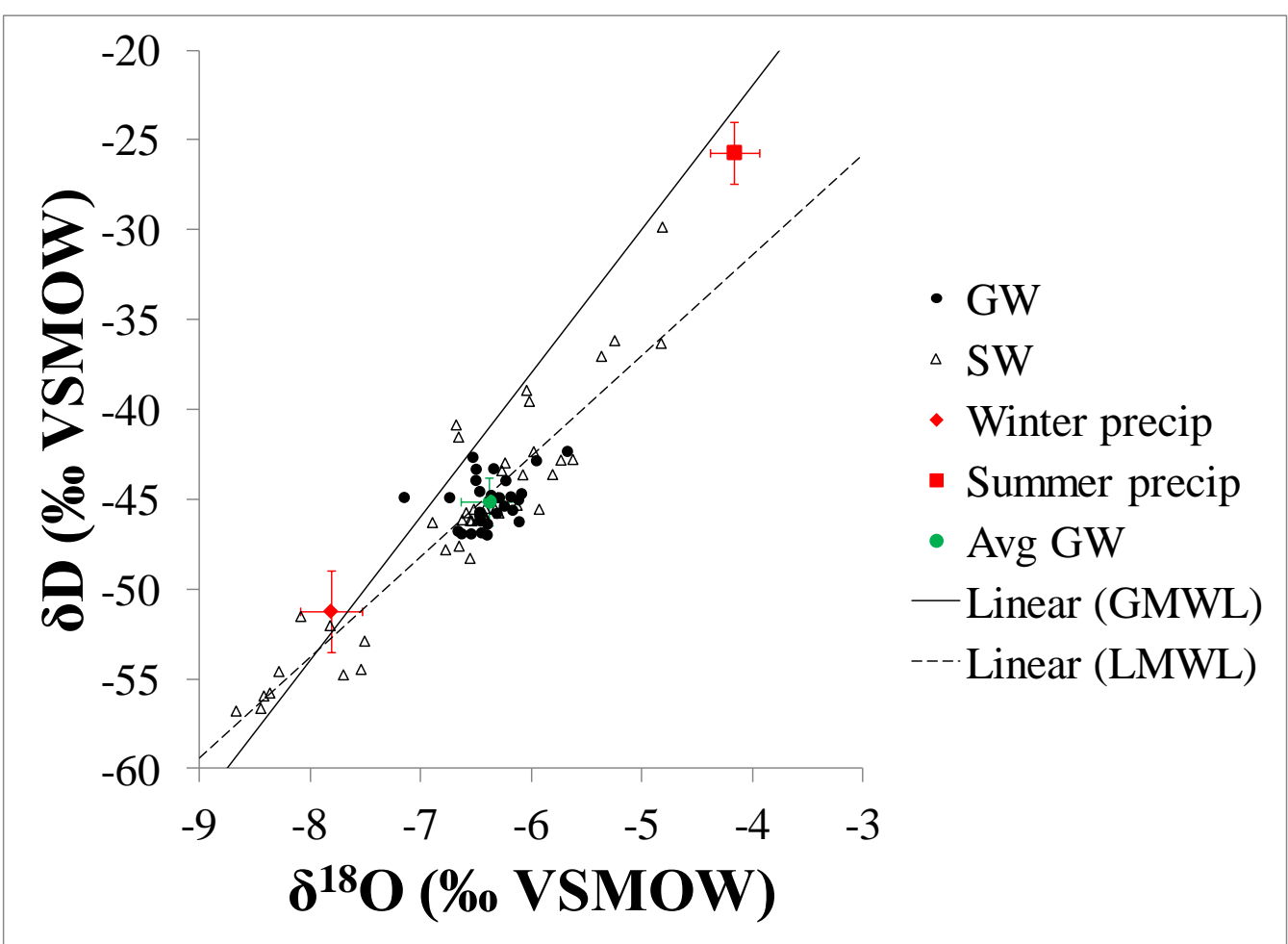

Figure 9. Stable water isotopes of groundwater, surface water, and precipitation samples.

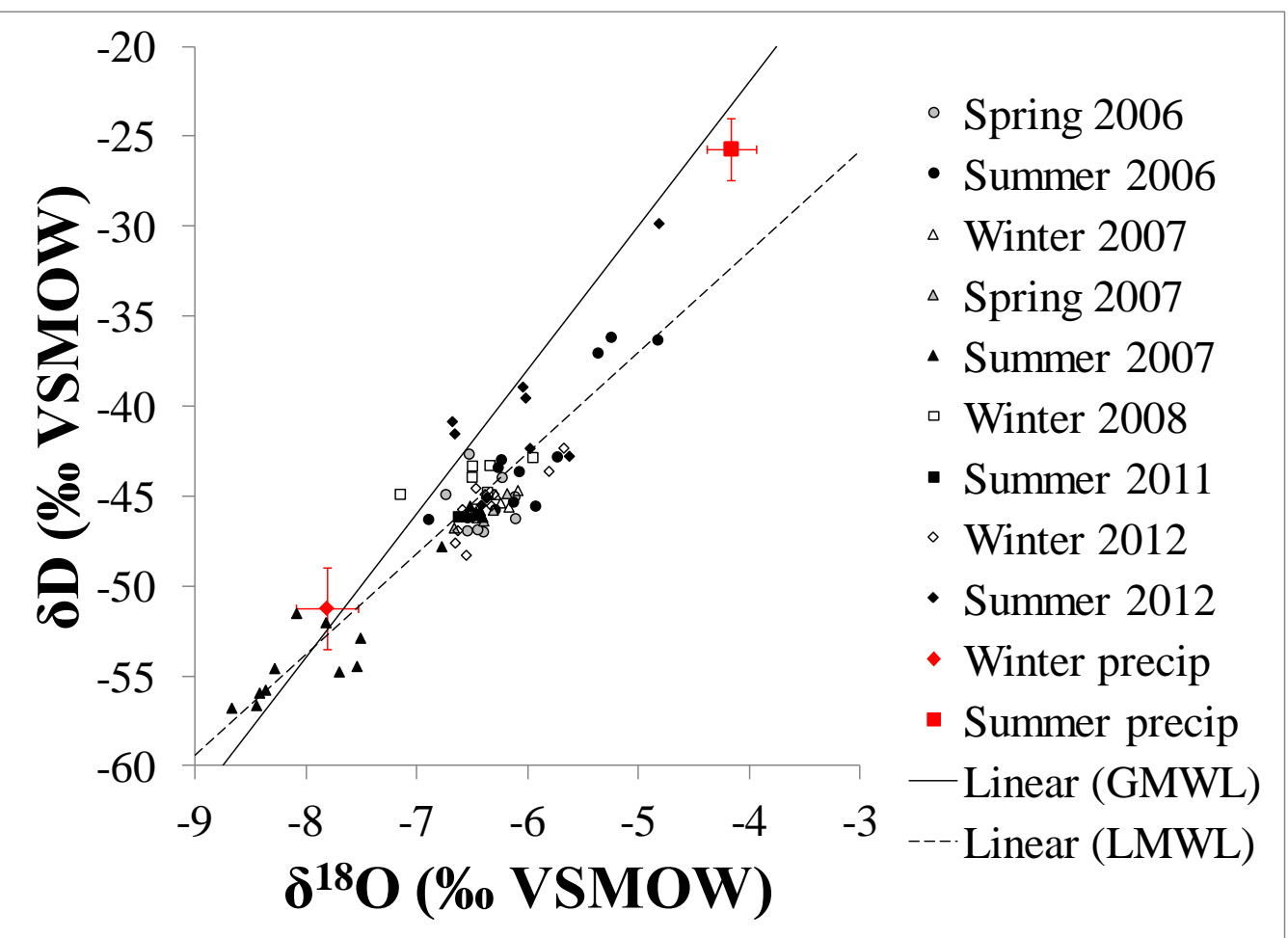

Figure 10. Stable water isotopes of groundwater and surface water samples for various seasons and years. 


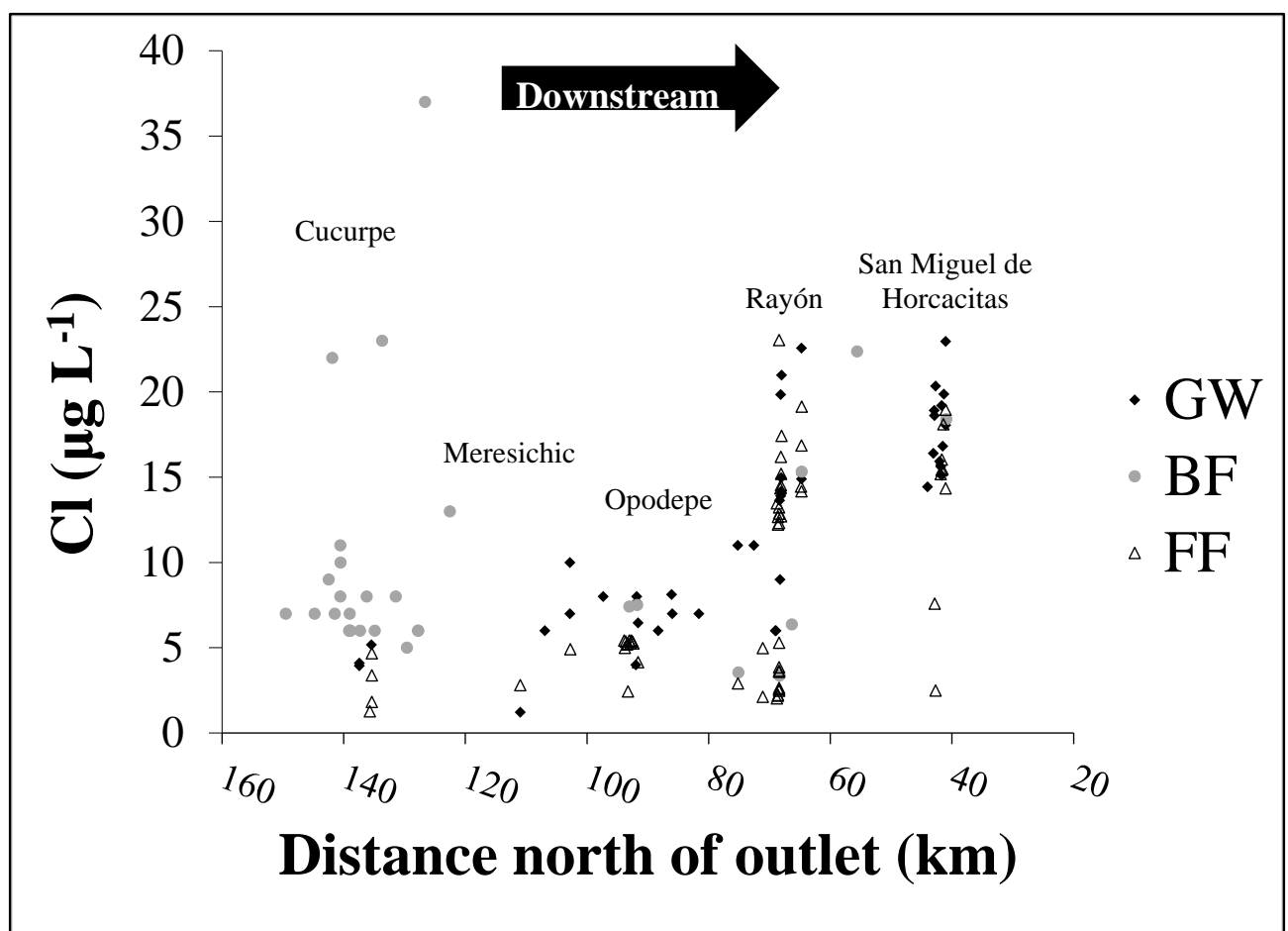

Figure 11. Chloride concentrations of groundwater (GW), baseflow (BF), and flood flow (FF) samples along a downstream gradient.

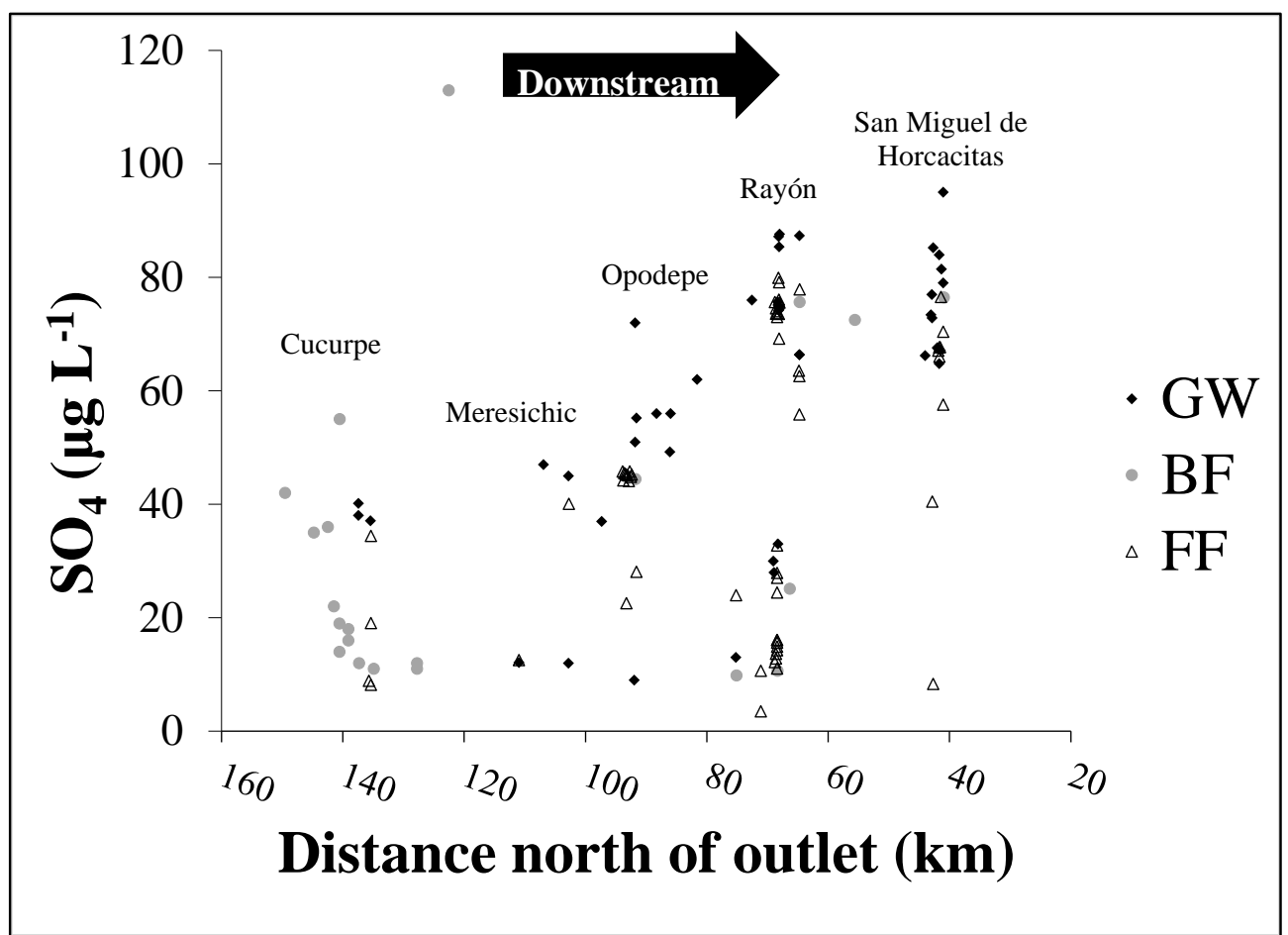

Figure 12. Sulfate concentrations of groundwater (GW), baseflow (BF), and flood flow (FF) samples along a downstream gradient. 


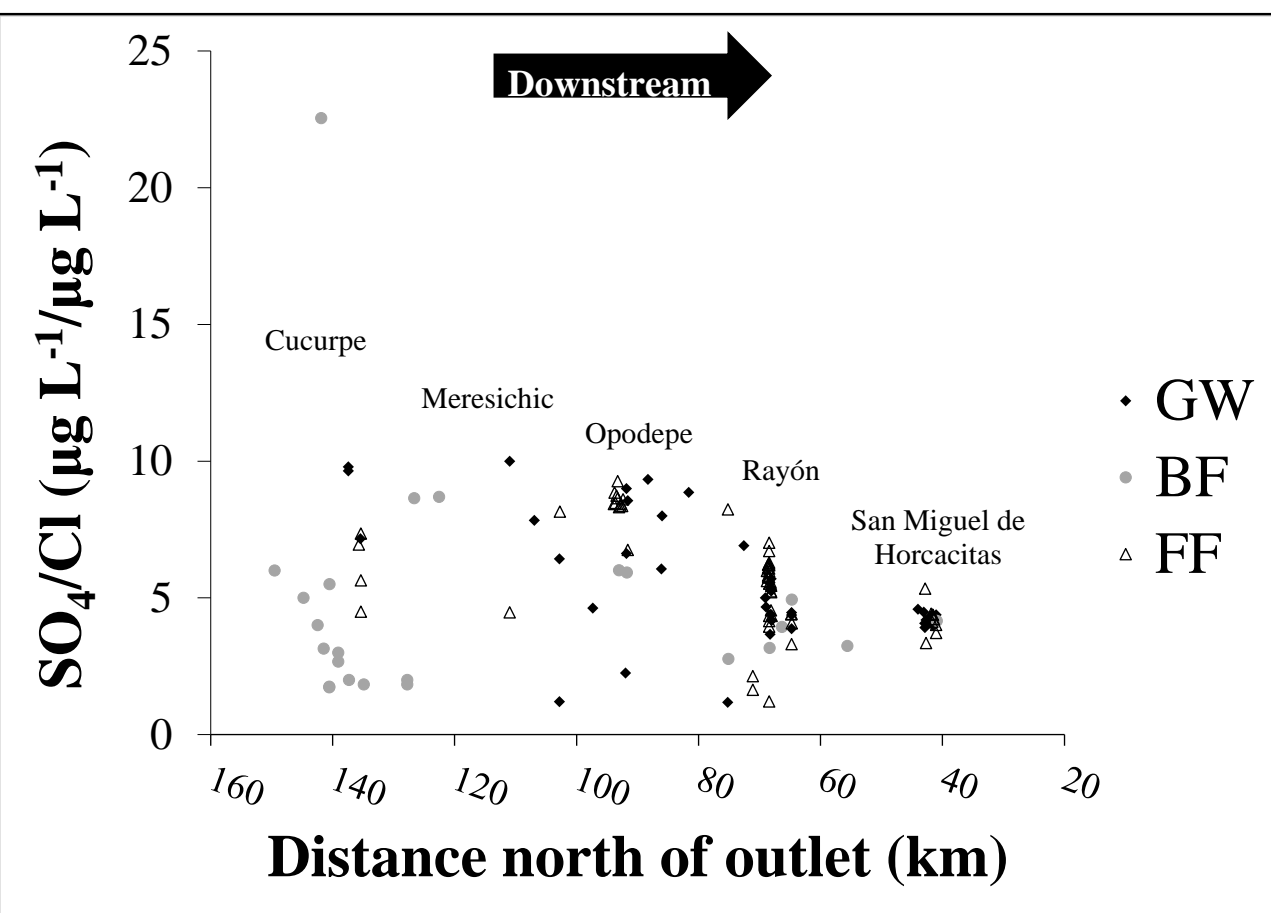

Figure 13. Sulfate to chloride ratio of groundwater (GW), baseflow (BF), and flood flow (FF) samples along a downstream gradient. 
a)

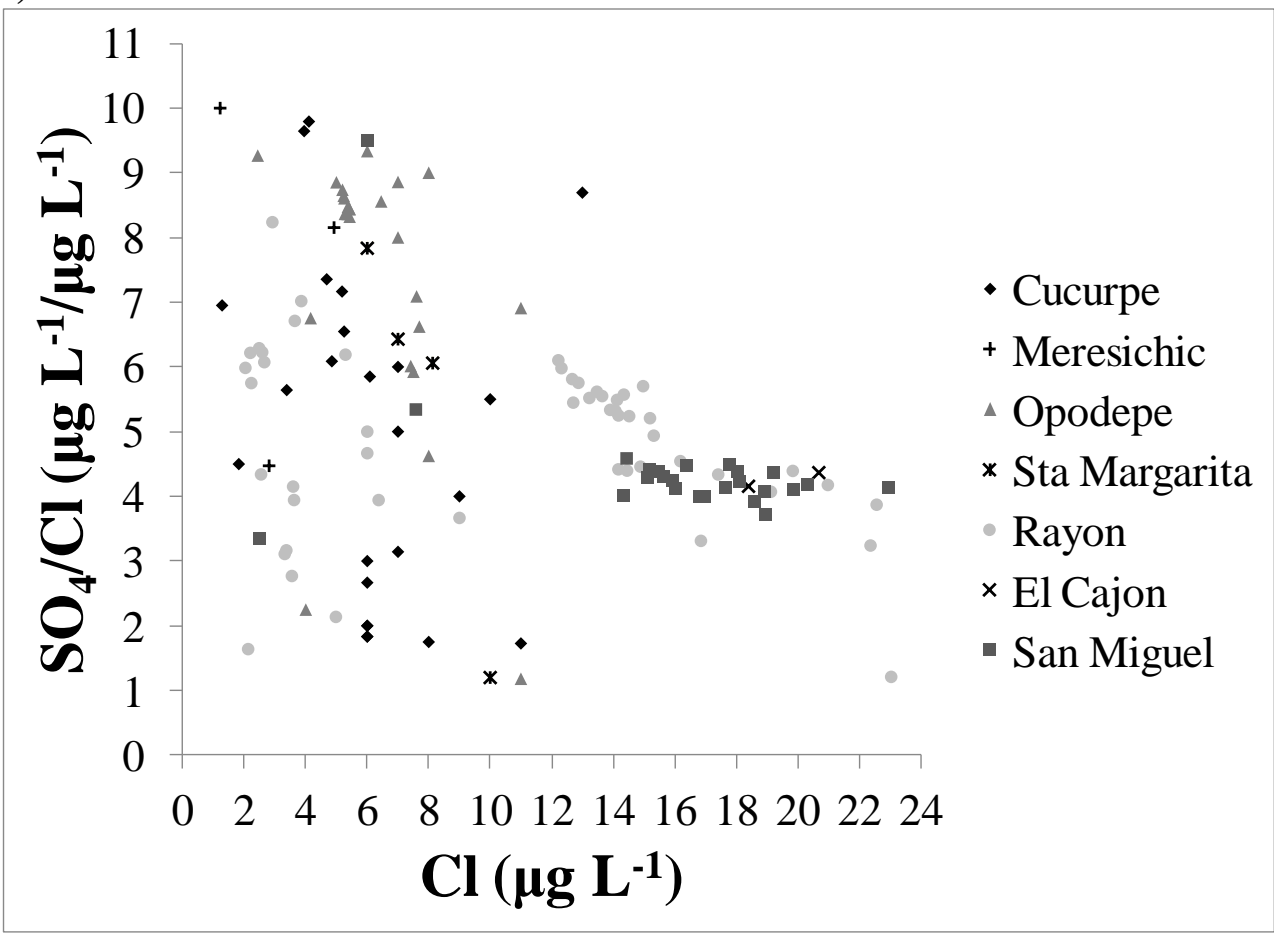

b)

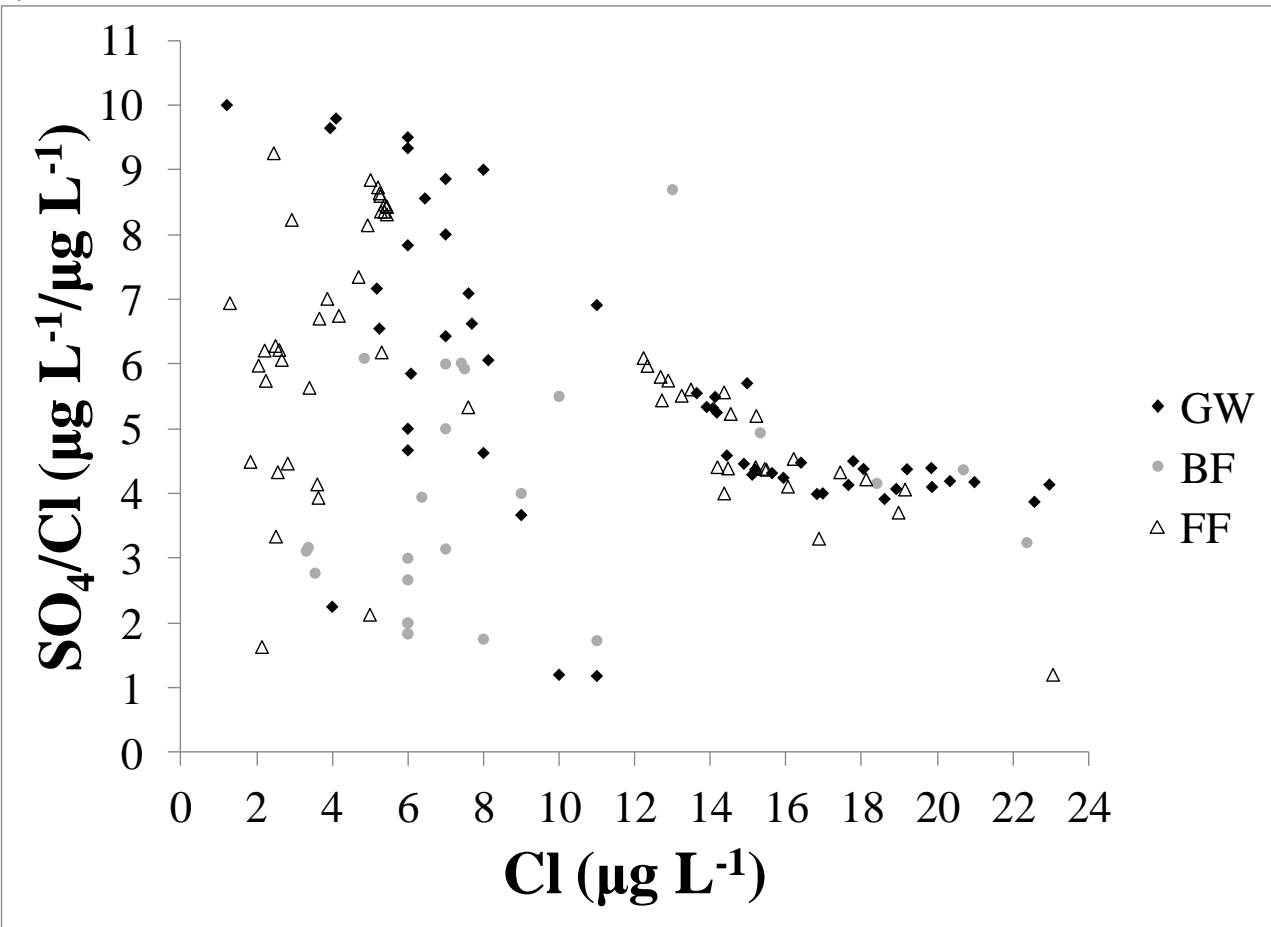

Figure 14. Sulfate-chloride ratio plotted against chloride for Río San Miguel by a) sampling location and b) sample type, including groundwater (GW), baseflow (BF), and flood flow (FF) samples. 
a)

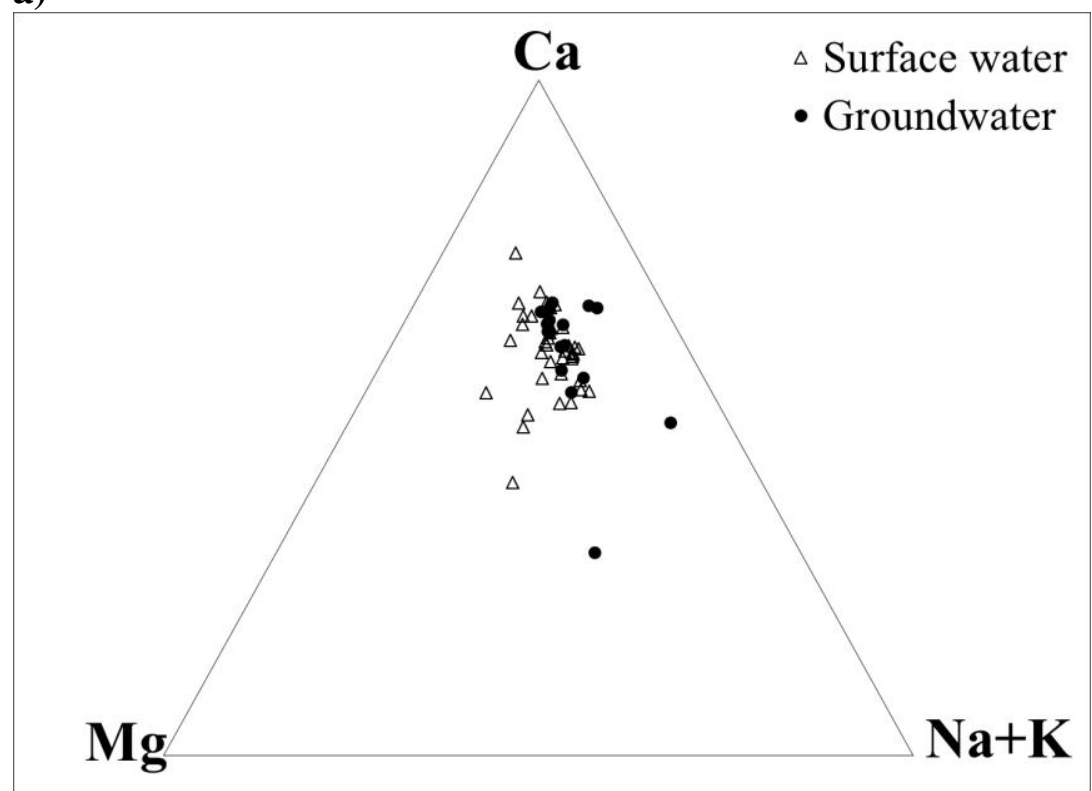

b)

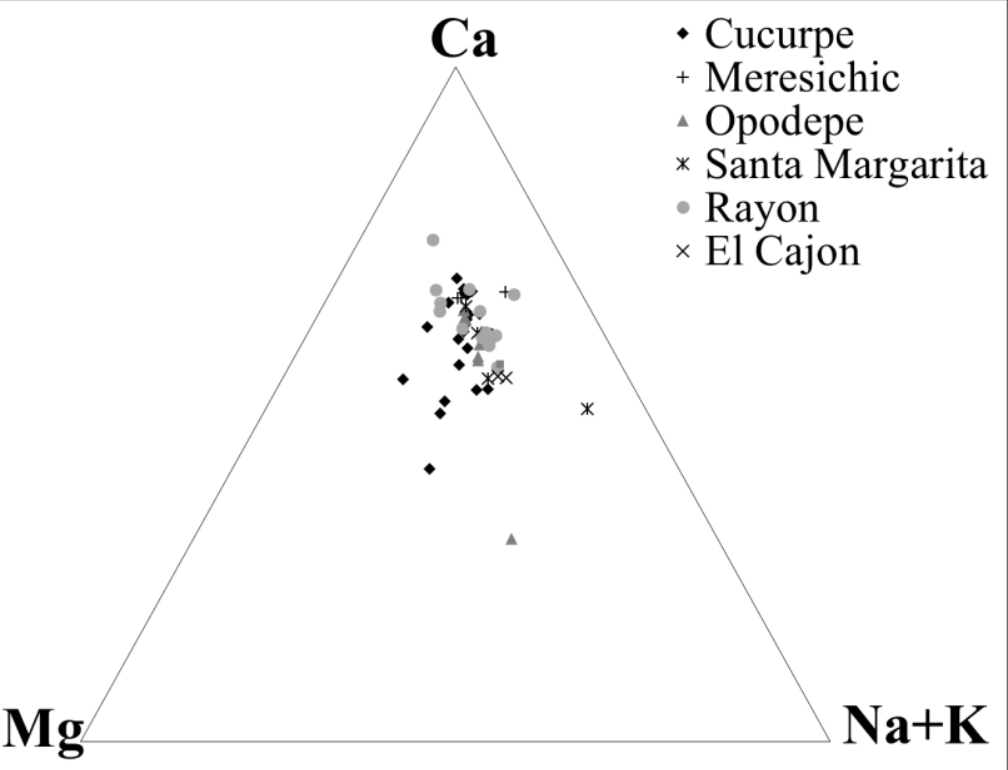

Figure 15. Ternary diagrams $\left(\mathrm{Na}^{+}+\mathrm{K}^{+}, \mathrm{Ca}^{2+}\right.$, and $\left.\mathrm{Mg}^{2+}\right)$ of water samples collected in the Río San Miguel Basin from 2005-2012, a) grouped by sample type; b) grouped by location. 


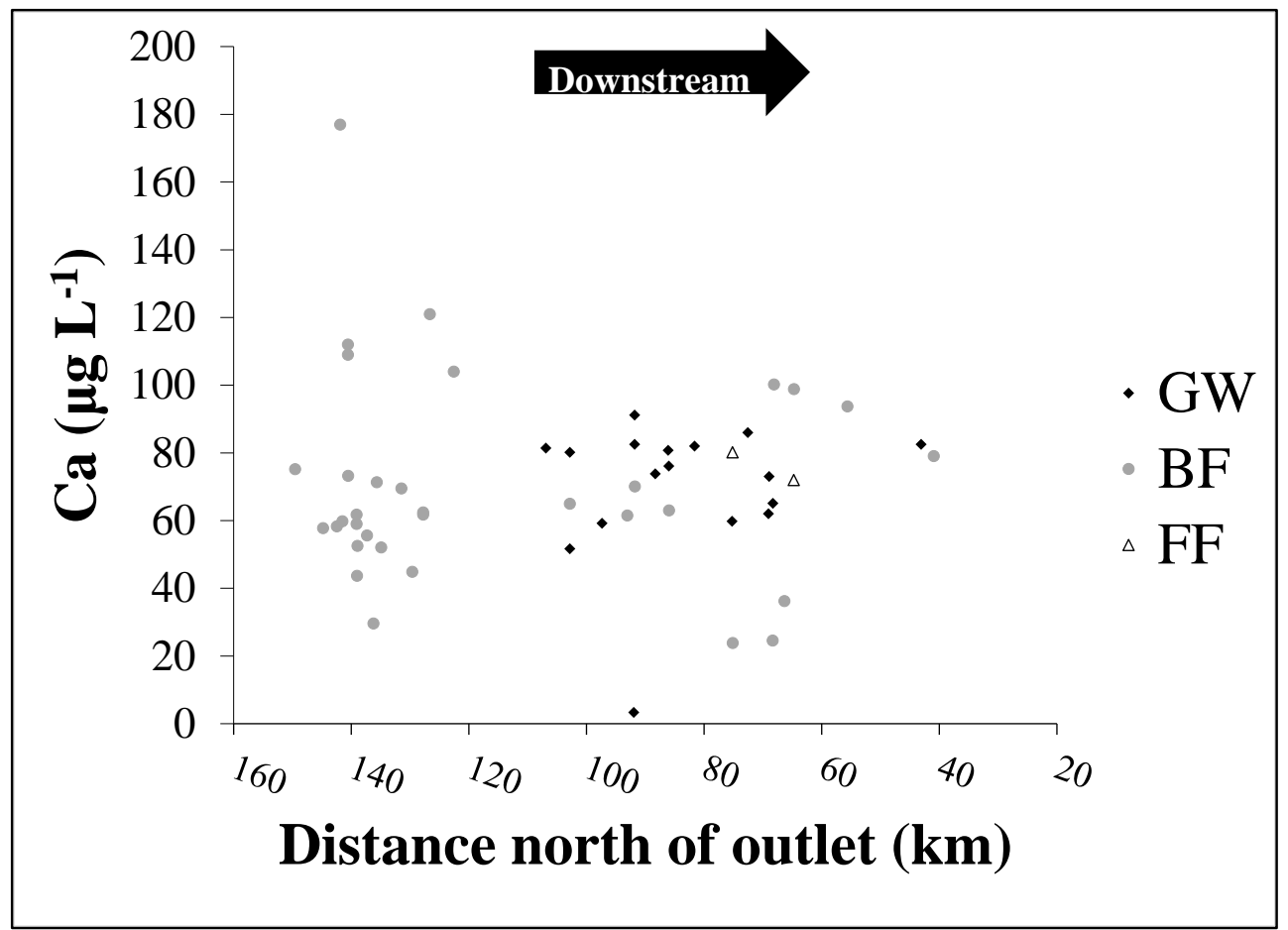

Figure 16. Sulfate to chloride ratio of groundwater $(\mathrm{GW})$, baseflow (BF), and flood flow (FF) samples along a downstream gradient.

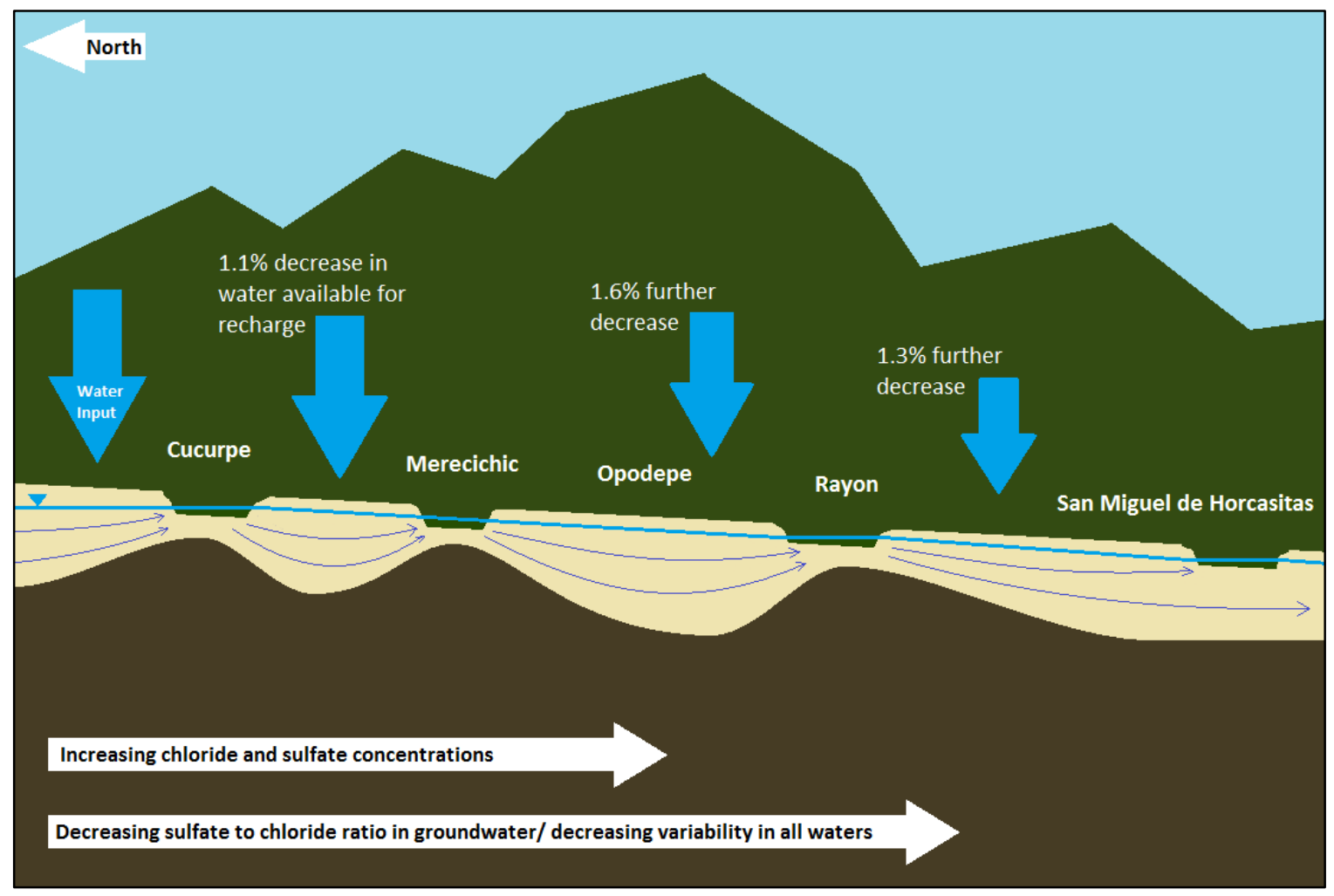

Figure 17. Conceptual flow model of the San Miguel Basin. Points of upwelling produce perennial reaches between sub-basins separated by shallow bedrock. 


\title{
APPENDIX B: Seasonality of Groundwater Recharge in the Basin and Range Province, Western North America
}

\author{
Kirstin L. Neff ${ }^{1}$, Thomas Meixner ${ }^{1}$, Lissette De La Cruz ${ }^{1}$, Hoori Ajami ${ }^{2}$ \\ ${ }^{1}$ University of Arizona, Department of Hydrology and Water Resources, Tucson, AZ, USA \\ ${ }^{2}$ University of New South Wales, School of Civil and Environmental Engineering, Sydney, Australia
}

\section{ABSTRACT}

For water-scarce communities in the western U.S., it is critical to understand groundwater recharge regimes and how those regimes might shift in the face of climate change, impacting the availability of groundwater resources. Watersheds in the Basin and Range Geological Province are characterized by a variable precipitation regime of wet winters and variable summer precipitation. The relative contributions to groundwater recharge by summer and winter precipitation vary throughout the province, with winter precipitation recharge dominant in the northern parts of the region, and recharge from summer monsoonal precipitation playing a more significant role in the south, where the North American Monsoon (NAM) extends its influence. Stable water isotope data of groundwater and seasonal precipitation from sites in Sonora, Mexico and the U.S. states of California, Nevada, Utah, Arizona, Colorado, New Mexico, and Texas were examined to estimate and compare groundwater recharge seasonality throughout the region. Contributions of winter precipitation to annual recharge vary from $69 \% \pm 42 \%$ in the southernmost Río San Miguel Basin in Sonora, Mexico, to $100 \% \pm 44 \%$ in the westernmost Mojave Desert of California. The Normalized Seasonal Wetness Index (NSWI), a simple water budget method for estimating recharge seasonality from climatic data, was shown to approximate recharge seasonality well in several winter precipitationdominated systems, but less well in basins with significant summer precipitation. 


\section{INTRODUCTION}

Most of the Earth's liquid freshwater is present as groundwater in subsurface aquifers, and groundwater is a primary source of freshwater for human communities and unique habitats around the world. However, population growth and increasingly extreme climate conditions have led to the depletion of groundwater resources across the globe (Famiglietti, 2014). In the United States, the West and particularly the communities of the Basin and Range Geologic Province are dependent upon groundwater for municipal supply, agricultural irrigation, and the maintenance of biodiverse arid and semi-arid ecosystems (Leenhouts el al, 2006). The only natural source of replenishment in these aquifer systems is groundwater recharge.

Groundwater recharge is the amount of water that infiltrates into the ground and eventually reaches the water table, augmenting the supply of groundwater. Recharge is difficult to measure directly, since much of the water that infiltrates in arid and semi-arid basins may never actually reach the water table, but is transpired by plants or evaporated back to the atmosphere (de Vries and Simmers, 2002). It is important to be able to estimate the amount of recharge in a basin so that educated decisions can be made to achieve sustainable water management. Existing strategies to estimate annual recharge include the water budget method, empirical modeling, and coupled land-surface modeling (ex. Serrat-Capdevila et al., 2013).

In the arid and semi-arid Basin and Range Province, recharge is characteristically small; less than $5 \%$ of annual precipitation in un-irrigated rangelands becomes recharge (McMahon et al., 2011). As aquifers have been pumped for human use in the past century, water tables have fallen across the region, indicating that pumping has outpaced natural replenishment by recharge. Declining water tables have negatively impacted 
native vegetation in the region (Stromberg et al., 1996; Nguyen et al., 2014). Meanwhile, global climate models are predicting dramatically increased probabilities of decadal and multi-decadal droughts in the American Southwest over the next century, increasing the stress on already scarce freshwater resources and the ecosystems that depend on them (Cook et al., 2015).

Predicting how recharge processes will respond to climate change is a difficult but necessary task to understand future water availability (Earman and Dettinger, 2011). As communities attempt to manage their groundwater resources for the future, accurate estimates of annual recharge are necessary to improve groundwater modeling and inform decision makers. This includes better characterization of seasonal variability in recharge rates, as well as how those seasonal trends will be impacted by predicted climate change on a regional scale (Serrat-Capdevila et al., 2007).

Jasechko et al. (2014) showed that the seasonal timing of recharge varies globally, with pronounced differences between summer and winter recharge ratios in arid and semi-arid zones, but stopped short of engaging with process-based explanations of this phenomenon. Isotopically-based seasonal recharge ratios in arid and semi-arid zones differed greatly from those estimated using a land surface model, indicating that regionalscale characterization and interpretation of recharge seasonality is necessary, as well as better methods for modeling recharge seasonality using available data resources. Ajami et al. (2012) proposed a new normalized seasonal wetness index (NSWI) to seasonalize recharge using readily-available climatic data that showed promise in its application in one semi-arid basin in the U.S. southwest. 
This study uses stable water isotopes of groundwater, summer precipitation, and winter precipitation to characterize recharge seasonality across a climate gradient in this geologically distinct region, and to address the following questions: how does recharge seasonality vary across the Basin and Range Province? What is the impact of climate and hydrogeology on the timing of recharge in these basins? How will climate change impacts propagate through these groundwater systems? Is the NSWI a useful tool for modeling recharge seasonality?

This research brings together data from published basin-scale studies, and involved processing and analyzing a number of historic stable water isotope data points available in the USGS National Water Information System (NWIS) database to expand the number of sites for which recharge seasonality is estimated from stable water isotopes. A new multi-year study of groundwater and surface water isotopes was conducted in the Río San Miguel Basin in Sonora, Mexico, in order to expand the domain of the study to the southern reaches of the Basin and Range (Neff et al., in prep). The seasonality of recharge in different basins is compared throughout the region, and spatial patterns are evaluated to identify drivers of recharge seasonality and quantity. Potential climate change impacts to recharge in the region are described in the context of those drivers.

\section{Study Area}

Quantifying and characterizing recharge in arid and semi-arid environments has been a focus of research in recent years (Dickinson et al., 2004; Hogan et al., 2004; Manning and Solomon, 2005; Anderson et al., 2006; Blasch and Bryson, 2007; Druhan et al., 2008; Manning, 2011; Ajami et al., 2012; Hopkins et al., 2014). The Basin and Range Province is of particular interest because of its productive aquifers and arid and semi-arid 
environment. The Basin and Range consists of north-south trending horst and graben structures across the western American deserts: the Mohave, the Great Basin, the Sonoran, and the Chihuahuan (McPhee, 1980). The Basin and Range extends across the U.S. states of Nevada, Utah, Arizona, New Mexico and west Texas, and in the Mexican states of Sonora and Chihuahua (Figure 1).

These horst-graben features consist of hard-rock units of igneous and metamorphic rock which broke apart along north-south running faults when the North American plate was released from compression about 30 million years ago (McPhee, 1980; Wernicke, 1981). The hard rock blocks faulted and tilted, producing the many parallel mountain ranges that are characteristic of the region. The low valleys between the basins filled with alluvium, the product of rock weathering, with a high porosity ideal for aquifer formation (McPhee, 1980). Given the desert climate of the region, the groundwater stored in these extensive alluvial basins has become a primary source of freshwater for communities throughout the region, in addition to sustaining spatially modest but biologically diverse riparian corridors (Leenhouts et al., 2006).

Two major climatic phenomena play important roles in determining the climate of the Basin and Range. First, the North American Monsoon (NAM) brings warm, convective storms to the region from the Gulf of Mexico and Sea of Cortez during the summer months (Hales, 1974; Hu and Dominguez, 2015). The second climatic phenomenon affecting the region is the El Niño/Southern Oscillation (ENSO), which is responsible for the cycling of wet and dry winter and spring precipitation seasons in the Basin and Range Province (Cayan and Webb, 1992). In an "El Niño" year, which occurs every 4-5 years, the Basin and Range often experiences greater than average winter 
frontal precipitation. Recently, an increasing influence of tropical cyclones has been noted in the late summer and fall months in the NAM zone (Camargo et al., 2008). These storms are characterized by high rainfall intensity, but also lower temperatures and are a potentially significant source of recharge.

\section{Recharge seasonality}

Prior studies of groundwater recharge in the western deserts of the U.S. have found that despite approximately one-third of yearly precipitation falling during highintensity, convective summer monsoon events, this precipitation type contributes comparatively less to groundwater recharge (e.g., Simpson et al., 1972; Blasch and Bryson, 2007; Wahi et al., 2008). Climate interacts with geology in Basin and Range aquifers to create a recharge regime encompassing the timing, location, and pathways of recharge. In Basin and Range systems, there are a variety of different recharge locations with different recharge pathways and rates, including mountain-block bedrock zones, mountain-front alluvial fan zones, diffuse recharge across the basin floor, and focused channel recharge (de Vries and Simmers, 2002; Wilson and Guan, 2004) (Figure 2).

The Basin and Range is characterized by steep elevation gradients between recharge sites in the mountain-block (via fractures) and mountain-front. Minimal recharge occurs dispersed over the basin floor (Stonestrom et al., 2004; Wahi et al., 2008; Meixner et al., in review). Mountain-block recharge (MBR) is recharge that occurs by percolation through the mountain bedrock over long time scales (Wilson and Guan, 2004). Mountain-front recharge can be a combination of surface runoff or shallow groundwater from the mountain block infiltrating in the alluvial fans of the basin, and runoff generated on the alluvial fans that recharges through ephemeral stream channels. 
Past work in Basin and Range systems indicates that mountain-system recharge (including mountain-block and mountain-front pathways) is dominated by winter frontal precipitation that coalesces around the mountain-fronts due to orographic precipitation effects (Wilson and Guan, 2004). Wahi et al. (2008) in the San Pedro and other studies in the region (e.g., Simpson et al., 1972; Winograd et al., 1998; Thiros and Manning, 2004) estimate that mountain-system recharge is made up of $75-90 \%$ winter precipitation. Recently, there has been increasing attention paid to the role of summer floods in recharging near-stream riparian groundwater (Vivoni et al., 2006; Baillie et al., 2007; Simpson et al., 2013). Additionally, several studies in the Basin and Range have shown that recharge from losing rivers passing through basins may be contributing a greater portion of recharge than previously thought (Guay et al., 2006; Druhan et al., 2008; Eastoe et al., 2008; Manning, 2011).

\section{METHODS}

\section{Stable water isotopes as tracers of seasonality}

Since the first study of its kind by Simpson et al. (1972), stable water isotope analysis has been used to determine the sources and timing of precipitation contributing to groundwater recharge in many Basin and Range systems (e.g., Winograd et al., 1998; Blasch and Bryson 2007; Wahi et al., 2008). Stable water isotope analysis for recharge seasonality is founded in the observed global pattern of the ratios ${ }^{2} \mathrm{H} / \mathrm{H}$ and ${ }^{18} \mathrm{O} /{ }^{16} \mathrm{O}$ in precipitation: less negative water occurs in warm, tropical zones and more negative waters occur in alpine and arctic zones, with all other water falling along a linear line relating the relative ratios of ${ }^{2} \mathrm{H} / \mathrm{H}$ and ${ }^{18} \mathrm{O} /{ }^{16} \mathrm{O}$, called the global meteoric water line (GMWL) (Craig 1961a). This pattern provides the basis for stable isotope analysis to distinguish the sources of meteoric waters by comparing all waters to a standard mean 
ocean water (Craig, 1961b). Here, water samples are compared against the reference Vienna Standard Mean Ocean Water (VSMOW) to determine their relative isotopic ratios (Clark and Fritz, 1997):

$$
\delta^{18} \mathrm{O}_{\text {sample }}=\left(\frac{0^{18} / 0_{\text {sample }}^{16}}{0^{18} / 0_{\text {VSMoW }}^{16}}-1\right) \cdot 1000 \% \text { VSMOW }
$$

Using volume-weighted mean $\delta^{18} \mathrm{O}$ and $\delta \mathrm{D}$ values of summer and winter precipitation as two endmembers, in addition to mean $\delta^{18} \mathrm{O}$ and $\delta \mathrm{D}$ values for groundwater in a basin, a simple two-endmember mixing model can be used to determine the fraction contribution of summer and winter precipitation to groundwater recharge.

Factors affecting the isotopic signature of precipitation

In the Basin and Range Province, climate, continental, and topographic effects contribute to the differentiation of isotopic values in regional precipitation. The isotopic composition of a vapor mass as it forms over the ocean and then travels across land is determined by Rayleigh fractionation processes. The composition of the initial vapor mass is a function of the temperature and pressure during cloud formation, with higher temperatures and pressures creating less negative vapor masses (Clark and Fritz, 1997). As vapor masses move across the continent, Rayleigh distillation proceeds during rainout, with heavier isotopes preferentially precipitating and raining out first. Topography plays a role, as vapor masses precipitate more as they move up an elevation gradient, such as a mountain ridge, leaving the most negative waters to continue moving across the continent in the rain shadow of the mountains.

In the western U.S., winter frontal storms begin as less negative air masses formed at cooler temperatures, and then traverse the coastal and Sierra Nevada mountains of California before entering the Basin and Range, so precipitation from these storms is 
generally more negative, growing more so the further from the Pacific coast that the precipitation occurs (Friedman et al., 2002; Lechler and Niemi, 2011). Snow deposited on mountaintops by these storms have some of the most negative $\delta^{18} \mathrm{O}$ and $\delta \mathrm{D}$ values in precipitation in the region (Earman et al., 2006). Summer monsoon precipitation in the Basin and Range tends to be less negative, as monsoon vapor masses form at higher temperatures and carry heavier isotopes further across the continent, often parallel to the comparatively smaller mountain ranges of the Basin and Range and thus experiencing less of the rain shadow effect than winter precipitation.

A major complication in using stable water isotopes to create mixing models of seasonal recharge in the Basin and Range is the mountainous setting. Not only do seasonal shifts in precipitation source and temperature of formation contribute to isotopic differences, but altitude effects can make it difficult to distinguish between high-elevation summer precipitation and low-elevation winter precipitation. The altitude effect on $\delta^{18} \mathrm{O}$ values in the Tucson basin was found to be $-0.16 \%$ per $100 \mathrm{~m}$ rise and in the Verde Valley, $-0.23 \%$ per $100 \mathrm{~m}$ rise (Wahi et al., 2008; Blasch and Bryson 2007). These data mean that summer recharge that occurs at high elevation could have a similar isotopic signature to winter recharge that occurs at low elevation and travels over a shorter flow path.

\section{Basin data collection}

Stable water isotope data were collected for winter precipitation, summer precipitation, and basin groundwater, primarily from previously published basin-scale studies (Table 1). Two additional data points were collected to fill out the domain of the Basin and Range Province: a new study site in the Río San Miguel Basin in northwestern 
Mexico (Neff et al., in-prep), and a collection of samples in the Carson Valley of northwestern Nevada from the National Water Information System (NWIS 2014). Criteria for basin selection

Basins were selected based on their location within the Basin and Range and the availability of robust datasets (Figure 2). Because of demonstrated inter-annual variability in isotopic values for precipitation in the region (Eastoe et al., 2004), sites were chosen for which data was collected over an extended time period (at least one year), and for which seasonal precipitation values were reported. The previously unpublished sites in Nevada and Mexico were chosen for their geographical locations to fill out the domain of the Basin and Range.

\section{Stable isotope data sources}

When using environmental tracers in groundwatear to measure recharge, it is assumed that groundwater is well-mixed and that the impact of a the variety of different recharge locations and flow path lengths present in a basin is dampened by integration of these waters in the aquifer. Geophysical tests of infiltration in a semi-arid system have shown this to be a reasonable assumption (Dickinson et al., 2004). Under this assumption, it is better to use regional average data than data from a single station when estimating recharge rates. It has been shown that vertical groundwater age gradients are less distinct in aquifers with pumping for agricultural irrigation and/or public supply, suggesting that developed aquifers will be better-mixed (McMahon et al., 2011). Assuming that recharge is well-mixed, and choosing appropriate sampling sites to ensure optimal mixing, the use of mixing models to determine the relative contribution of seasonal precipitation to annual recharge is supported. 
In most cases, the average or volume-weighted average $\delta^{18} \mathrm{O}$ and $\delta \mathrm{D}$ values for winter precipitation, summer precipitation, and groundwater were reported in the source studies (Table 1) (Thiros and Manning, 2004; Blasch and Bryson, 2007; Druhan et al., 2008; Eastoe et al., 2008; Wahi et al., 2008). Lacking this explicit data, average values were calculated from reported sample datasets or interpreted from published figures showing individual samples (Kalin, 1994; Winograd et al., 1998; Izbicki et al., 2000; Wright, 2001; Friedman et al., 2002; Rose et al., 2003; Newton et al., 2009). For some basins, a variety of groundwater sample types were collected, including spring water and basin groundwater (Newton et al., 2009; Druhan et al., 2008). In these cases, the stated average value or a representative value based on basin groundwater samples was used. In the Spring Mountains (NV), the only groundwater data reported came from mountain springs, not basin groundwater (Winograd et al., 1998). In the Salt Lake Valley and Hueco Bolson aquifer, basin groundwater and seasonal precipitation values were taken from different sources (Friedman et al., 2002; Thiros and Manning, 2004 Druhan et al., 2008; Eastoe et al., 2008). In the Mojave Desert, soil water from cores of the unsaturated zone were used instead of basin groundwater values (Izbicki et al., 2000). A representative value for core water samples unaltered by Rayleigh distillation and therefore representative of recharge was reported.

In two cases, precipitation values were adjusted to reflect the elevation difference between precipitation and groundwater sample collection sites. In the Tucson Basin, the value used for winter precipitation was the average seasonal value for the high elevation Palisades Ranger Station sample site, to reflect the importance of mountain-system recharge in that basin (Wright, 2001). The summer precipitation value was taken from 
low-elevation sample sites to reflect the greater spatial heterogeneity in the location of monsoon precipitation. In the Sacramento Mountains, precipitation samples collected at elevation in the mountains were adjusted down-gradient using the isotope-elevation gradient observed in the Tucson basin by Wright (2001):

$$
\begin{aligned}
\delta^{18} \mathrm{O}_{\text {basin }} & =\delta^{18} \mathrm{O}_{\text {mountain }}+\left(0.19 \frac{\% 0}{100 m} \times \Delta \text { elevation }\right) \\
\delta D_{\text {basin }} & =\delta D_{\text {mountain }}+\left(0.8 \frac{\% 0}{100 m} \times \Delta \text { elevation }\right)
\end{aligned}
$$

This was done to adjust for the high elevation locations of the precipitation sampling sites. Since the foothills of the Sacramento Mountains, where groundwater samples were collected are at lower elevation, this was done to better reflect the isotopic values of precipitation in the foothills, where much of the annual rain occurs.

In the Hueco Bolson, four bulk seasonal precipitation samples were collected over the course of one year. Unexpectedly, the reported seasonal $\delta^{18} \mathrm{O}$ and $\delta \mathrm{D}$ values indicated that winter precipitation was the not lightest isotopically (Eastoe et al., 2008). Interpretation of stable water isotope values of shallow groundwater in the northern Hueco Bolson by Druhan et al. (2008) suggest that recent recharge from winter storms in that area resulted from precipitation with a $\delta^{18} \mathrm{O}$ value of $-11 \%$, lower than even the lowest value for precipitation reported by Eastoe et al. (2008). Assuming this winter precipitation would not feature a deuterium excess indicative of re-evaporated precipitation, a $\delta \mathrm{D}$ value was calculated using the GMWL, and these values were used as the winter precipitation endmembers for the Hueco Bolson (Craig, 1961b):

$$
\delta \mathrm{D}=8.0 \times \delta^{18} \mathrm{O}+10
$$


This approach made the winter precipitation endmembers for the Hueco Bolson and Sacramento Mountains more similar, as expected given their geographic proximity.

\section{Seasonalization of recharge using stable water isotopes}

Seasonal precipitation endmember $\delta^{18} \mathrm{O}$ and $\delta \mathrm{D}$ values were used to determine their relative contribution to basin groundwater. This analysis relies on a mass-balance two-component mixing model approach to determine the relative contributions of source water with differing isotopic signatures (Simpson et al., 1972; Winograd et al., 1998; Jasechko et al., 2014). Concentrations of a conservative tracer are determined in the two sources and related to their concentration in basin groundwater to determine the percent volume contribution of each (Genereux and Hooper, 1998). The model is solved to determine the fraction winter precipitation $\left(f_{w}\right)$ :

$$
\begin{gathered}
{\left[\delta^{18} \mathrm{O}\right]_{g w}=f_{w}\left[\delta^{18} \mathrm{O}\right]_{\text {winter precip }}+\left(1-f_{w}\right)\left[\delta^{18} \mathrm{O}\right]_{\text {summer precip }}} \\
f_{w}=\frac{\left[\delta^{18} \mathrm{O}\right]_{g w}-\left[\delta^{18} \mathrm{O}\right]_{\text {summer precip }}}{\left[\delta^{18} 0\right]_{\text {winter precip }}-\left[\delta^{18} 0\right]_{\text {summer precip }}} \\
f_{s}=1-f_{w}
\end{gathered}
$$

This method was repeated using $\delta \mathrm{D}$ values in place of $\delta^{18} \mathrm{O}$ values for each of the basins, yielding two estimates of winter recharge fraction.

This approach is complicated by the nature of the endmembers. The $\delta^{18} \mathrm{O}$ and $\delta \mathrm{D}$ values of summer and winter precipitation are represented as a volume-weighted average of precipitation samples, but samples can have significant variation in isotopic values seasonally. There is uncertainty in such studies, but they remain useful for estimating recharge seasonality in the absence of economical measurement alternatives. Where statistics on the variation of basin groundwater and seasonal precipitation endmembers 
were available, a suite of 9 estimates for the fraction winter recharge were calculated using the upper and lower end standard deviation values of each endmember and propagated through the fraction winter recharge calculation (Neff et al., in-prep) (Table

3). This was done with the goal of quantifying the uncertainty inherent not only in sampling groundwater, but in averaging seasonal precipitation samples that may vary greatly within a season. In the cases where standard deviations of mean endmembers are known, uncertainty is reported as the standard deviation of the suite of 18 estimate calculations ( 9 estimates each for $\delta^{18} \mathrm{O}$ and $\left.\delta \mathrm{D}\right)$. In cases where a winter recharge fraction estimate was reported explicitly in the source study, that value was also reported here in addition to the average of the mixing models.

\section{Creation of isoscapes for groundwater, seasonality of recharge, and seasonality of precipitation}

Once final values for fraction winter recharge had been determined for all basin, these values were used to create an interpolated isoscape of recharge seasonality across the Basin and Range. Where winter recharge fraction values were reported in the literature, they were used in place of the averages calculated here to conduct the interpolation. Basin winter recharge fraction values were used to create a tension spline interpolation in ArcMap 10. A tension spline interpolation was chosen because it creates the smoothest surface, with the most gradual change between input data points. Tension spline interpolations were also created for winter precipitation fraction as determined from mean monthly precipitation values from nearby long-term precipitation stations (WRCC, 2015), mean $\delta^{18} \mathrm{O}$ of groundwater, mean $\delta^{18} \mathrm{O}$ of winter precipitation, and mean $\delta^{18} \mathrm{O}$ of summer precipitation. 


\section{Seasonalization of recharge using NSWI}

While isotopically-derived seasonal recharge estimates provide a way to observe recharge seasonality, they are time-intensive and costly to determine. An alternative that uses readily available climatic data in a physical process-based model to estimate seasonal recharge fractions could increase the applicability of recharge seasonalization in modeling the hydrologic cycle. Ajami et al. (2012) proposed the use of a Normalized Seasonal Wetness Index (NSWI) to calculate seasonal scaling factors for recharge in groundwater basins from climatic data. The NSWI is a simple water budget model which assumes that any precipitation not evapotranspired is available for groundwater recharge. Ajami et al. (2012) demonstrated the effectiveness of the NSWI in estimating the seasonal fractions of precipitation in the Upper San Pedro Basin, and here we expand that analysis to the other U.S. basins examined in this study.

North American Regional Reanalysis (NARR) results from 1979 to 2009 were used to calculate the NSWI for each NARR node contained in the study basins using both potential evapotranspiration (PET) and actual evapotranspiration (AET) from the NARR dataset (Ajami et al., 2012):

$$
\begin{aligned}
& N S W I_{w}, A E T=\frac{\left(\frac{P_{w}}{A E T_{w}}\right)}{\left(\frac{P_{w}}{A E T_{w}}+\frac{P_{s}}{A E T_{s}}\right)} \\
& N S W I_{w}, P E T=\frac{\left(\frac{P_{w}}{P E T_{w}}\right)}{\left(\frac{P_{w}}{P E T_{w}}+\frac{P_{s}}{P E T_{s}}\right)}
\end{aligned}
$$

Summer and winter total lengths of precipitation were calculated for each season using a MATLAB script to aggregate the seasonal totals. NSWI values using PET and AET were calculated for every NARR node in a basin for each year. NARR ET data has been shown 
to be well-correlated to Ameriflux measurements of ET in the southwestern U.S.

(Dominguez et al., 2009).

Estimates for total annual recharge length for each NARR node within the study basins were calculated from empirical equations developed for regions within the Basin and Range, and modified here to be independent of basin area. In the northwestern extent of the Basin and Range, the Maxey-Eakin method was applied to the Salt Lake Valley, Carson Valley (NV), central Nevada, Spring Mountains (NV), and Mojave Desert (CA) sites (Maxey and Eakin, 1949). Maxey-Eakin was derived empirically from data for the Great Basin Desert:

$$
R_{M E}=\sum_{i=1}^{5} a_{i} \times P_{i}
$$

where $a_{i}$ is a scaling factor determined by the amount of annual precipitation $\left(P_{i}\right)$ (Table 2). For all three Arizona sites, the Anderson equation developed for the San Pedro basin was used (Anderson et al., 1992):

$$
\log \left(R_{a}\right)=-1.4+0.98 \times \log \left(P_{a}\right)
$$

Similar to the Maxey-Eakin method, the Anderson equation assumes that any rainfall less than 8 inches results in no recharge. Finally, for the two Río Grande Valley sites, the Waltemeyer (2001) method was applied, which was developed from a regression analysis of water balance estimates in the Tularosa Basin, southern New Mexico:

$$
R=\left(1.7 \times 10^{-4}\right) \times A^{1.35} \times P^{1.65}\left(\frac{1}{A}\right)
$$

The Waltemeyer method was modified from its original form to produce recharge estimates normalized by and therefore independent of area. 
Empirical recharge estimates for each NARR node were multiplied by the isotopic, NSWI-AET, and NSWI-PET winter scaling factors to determine an estimate of winter recharge length for each node for each year. The values for individual NARR nodes were averaged across all nodes in a basin for each year to determine an average winter recharge length for each basin for each year.

\section{RESULTS AND DISCUSSION}

\section{Stable water isotope signatures of winter precipitation, summer precipitation, and basin groundwater in study basins}

For every basin, the isotopic value of groundwater fell between summer and winter precipitation, with winter precipitation being more negative than summer precipitation (Table 4 and Figure 3). The basin with the most negative waters was the Salt Lake Valley, the northernmost basin, and the least negative waters occurred in the Río San Miguel Basin, the southernmost basin.

Groundwater values for many of the basins exhibit an evaporative trend, plotting slightly to the right of their basins' local meteoric water lines (LMWLs), which would connect the winter and summer precipitation endmembers (Figure 3). Evaporation impacts the isotopic composition of water through differential kinetic fractionation between deuterium and oxygen-18 (Clark and Fritz, 2007). When evaporation occurs, lighter isotopes preferentially transition from the liquid to vapor phase, leaving the heaver isotopes in the water body. This kinetic fractionation occurs at a faster rate for oxygen18 , leaving a deuterium excess in the water body. On $\delta^{18} \mathrm{O}-\delta \mathrm{D}$ plots, this manifests as a break from the local meteoric water line with a shallower slope that is dependent on relative humidity. This evaporative trend is most pronounced at the Mojave Desert site (Figure 3). 


\section{Spatial patterns in stable water isotopic composition of seasonal precipitation and groundwater}

Groundwater in the Basin and Range is more negative in the north than in the south (Figure 5b). The spatial distribution of mean groundwater $\delta^{18} \mathrm{O}$ values highlight some of the topographic features of the region. In the region east of the Sierra Nevada, groundwaters are more negative. In Arizona and New Mexico, isolines follow the shape of the Colorado Plateau. The emergence of topographical features in the groundwater isotope dataset indicates that topographical effects on precipitation isotopic composition are recorded in basin groundwater.

Winter precipitation $\delta^{18} \mathrm{O}$ values have a similar spatial distribution to mean groundwater in the region, supporting the dominance of winter precipitation in annual recharge (Figures 5b and 6a). Summer precipitation has a slightly different spatial pattern, with isolines at the east and west edges of the Basin and Range trending southward (Figure 6b). For winter precipitation and groundwater, the isolines trend northward at the east and west. This difference in spatial patterns may be due to the influence of monsoon precipitation entering the Basin and Range from the south, and diminishing further northward, eastward, and westward within the region. Summer precipitation $\delta^{18} \mathrm{O}$ values are also less negative than winter precipitation and groundwater values across the domain. (Figure 6b).

The interpolations for $\delta^{18} \mathrm{O}$ of winter precipitation and mean basin groundwater compare favorably with similar interpolations made for $\delta^{18} \mathrm{O}$ of river water across the U.S. (Kendall and Coplen, 2001). The isolines in Figures $5 \mathrm{~b}$ and $6 \mathrm{a}$ have a similar shape to those of the river water interpolations, indicating that the results of this study are supported by other datasets. The spatial distribution of $\delta^{18} \mathrm{O}$ values of summer 
precipitation in the study area does not match the distribution of $\delta^{18} \mathrm{O}$ values in river water effectively, suggesting that streamflow throughout the Basin and Range is also dominated by winter precipitation.

\section{Spatial patterns in seasonality of precipitation and recharge}

The seasonality of precipitation in the Basin and Range shifts from winterdominated in the western parts of the region to summer-dominated in the southeastern part of the basin (Figure 4a). There is a steep transition zone from winter-dominated to summer-dominated across central and southern Arizona and northern Sonora. This result reflects the greater influence of the NAM in Arizona and New Mexico, and summer precipitation in areas of the Basin and Range closer to the U.S. Gulf Coast.

While some parts of the Basin and Range do receive most of their precipitation in the summer months, winter precipitation makes up greater than $50 \%$ of recharge throughout the region (Table 4 and Figure 4b). A monsoon signal in winter recharge fraction reaching from northern Mexico up into the Four Corners area is apparent in the southern Basin and Range, where relatively more recharge comes from summer precipitation. But even in these basins, recharge is still dominated by winter precipitation. A pocket of greater fraction winter recharge is visible near the Hueco Bolson Basin site near El Paso, Texas. This pocket of greater winter dominance in recharge may simply be an artifact of endmember selection, or it may be the result of mixing with higher elevation and high latitude waters, often snowmelt, entering the aquifer from the Rio Grande River, that would cause the $\delta^{18} \mathrm{O}$ and $\delta \mathrm{D}$ values of mean basin groundwater to be more negative than recharge occurring from precipitation within the basin.

In the southern Basin and Range, there is the greatest discrepancy between the seasonality of precipitation and the seasonality of recharge, as shown by the ratio of 
fraction winter recharge to fraction winter precipitation (Figure 5a). This marked difference illustrates the disproportionate impact of recharge from winter precipitation as compared to recharge from summer precipitation in the southern Basin and Range. Summer precipitation must be partitioned into recharge less efficiently than winter precipitation. This difference is likely because evaporative demand at the time of precipitation and the intensity of the precipitation event are factors in the partitioning of precipitation to recharge. Frontal, low-intensity storms arriving in the Basin and Range Province from the Pacific Coast during the fall, winter and spring months result in a higher rate of recharge per unit rainfall. There is less evaporation of rainfall during these frontal storms because they do not occur in summer at peak solar radiation. Furthermore, higher storm intensities during monsoon precipitation cause infiltration capacity of soils to be reached more quickly, leading to greater partitioning of precipitation into quick runoff. Not only can a greater fraction of precipitation infiltrate and recharge during the typical winter storm, but a lesser fraction is lost to the atmosphere via re-evaporation. The result is a greater recharge efficiency of winter precipitation than of summer precipitation.

Uncertainty in the fraction winter recharge calculated from isotopic data is high for all sites, reflecting uncertainty arising from high variability in endmember datasets (Table 4). Other sources of uncertainty exist beyond the quantified variability. A central question in the validity of using stable water isotopes to estimate recharge seasonality is: on what time scales are these values representative of the system? In the Middle San Pedro Basin in southern Arizona and the Espanola Basin in central New Mexico, groundwaters with radio carbon ages up to 35,000 years BP have been found (Manning, 
2011; Hopkins et al., 2014). In the Sacramento Mountains, however, waters a generally younger, on the order of thousands of years (Eastoe and Rodney, 2014). Proxy records for paleoclimate provide insights into past climate in the region. The $\delta^{18} \mathrm{O}$ of calcite record at Devils Hole in southern Nevada indicates that prior to 17.5 years BP, the climate of the western U.S. was warmer and wetter (Winograd et al., 2006). This finding is corroborated from studies of paleolake shores in the modern day Great Basin desert (Lyle et al., 2012). Meanwhile, paleo-vegetation recorded in packrat middens in the Mojave Desert indicate that between 6,800 and 5,060 years ago, the region was drier than the present (Spaulding 1991).

Variability in past climate within the age of groundwaters present today could impact the isotopic composition of groundwater. A weak monsoon would mean a southward shift in the geographic center of the monsoon, and fewer less negative vapor masses reaching the southern Basin and Range. This change would mean a shift in the bulk seasonal isotopic value of summer precipitation toward more negative $\delta^{18} \mathrm{O}$ and $\delta \mathrm{D}$ values, making it more difficult to distinguish between current winter recharge occurring in the mountain-blocks and past summer precipitation. Alternatively, an intensification of the monsoon would increase the amount of annual precipitation with less negative $\delta^{18} \mathrm{O}$ and $\delta \mathrm{D}$ values. A warmer, wetter past climate might have resulted in less negative groundwater, as larger precipitation events are associated with more negative isotopic values (Dansgaard, 1964). Because the region has been both wetter and drier in the time frame in which present day groundwater recharged, it is difficult to say if their might be a bias in the winter recharge fraction estimations. Assuming that most of the groundwater 
samples used to determine these values were not taken from very deep wells or wells in areas of upwelling of very old groundwater, the estimates here are reliable.

\section{Evaluation of the NSWI in estimating seasonal recharge}

Comparison of isotopically-scaled and NSWI-scaled winter recharge fractions indicate that the NSWI can be applied to many sites in the Basin and Range Province to successfully estimate seasonal recharge volumes. The northernmost Great Basin sites had the strongest correlations between isotopically- and NSWI-scaled recharge lengths (Figures 7 and 10). These sites, whose recharge was estimated using the Maxey-Eakin method, had the highest $\mathrm{R}^{2}$ values, and three had best fit slopes greater than 0.9 (1.0 being ideal) for both AET and PET-based estimates: the Salt Lake Valley, Carson Valley, and Spring Mountains. The Mojave Desert and central Nevada sites had best fit slopes over 0.7 for AET, but performed better using PET-based estimates (Figure 10). All the Great Basin sites except the Salt Lake Valley had near-zero best fit y-intercept values. Thus, the NSWI worked best in the Carson Valley and Spring Mountains, two sites located at the eastern edge of the Mojave Desert.

The NSWI did less well in estimating recharge seasonality in the Arizona basins calculated using the Anderson equation (Figures 8 and 10). Both the Tucson and San Pedro basins experienced greater scatter $\left(\mathrm{R}^{2}\right.$ values between 0.6 and 0.9$)$, but with best fit slopes greater than 0.8 (Figure 10). The Tucson basin had a best fit y-intercept deviating from zero by more than one, and in the San Pedro it was less. In the Verde Valley, scatter was low $\left(\mathrm{R}^{2}\right.$ values greater than 0.9$)$ and correlation to observed isotopic values was high (best fit slope approached 1), but the best fit y-intercept deviated from 0 by nearly 5 .

The Río Grande basins calculated using the Waltemeyer method had the greatest scatter (Figures 9 and 10). The Hueco Bolson basin had the weakest correlation to 
isotopically-scaled recharge estimates. With a best fit slope less than 0.7 , the NSWI consistently underestimated winter recharge, with underestimation increasing with total annual recharge. Meanwhile, the Sacramento Mountains exhibited high correlation between NSWI and isotopically-scaled recharge estimates (best fit slope near 1), but had the largest best fit y-intercept deviation from zero (Figure 10).

There is a strong positive correlation between the $\mathrm{R}^{2}$ values of NSWI- and isotopically-scaled winter recharge estimates and winter precipitation fraction as determined from isotopes (Figure 11). The scatter between NSWI- and isotopicallyscaled recharge was greater for basins that receive more of their annual precipitation in the summer. The difference between $\mathrm{R}^{2}$ values for AET- and PET-based NSWI were also greater for basins with more contribution from summer recharge (Figure 10). There are several possible hypotheses to explain this trend. First, the NSWI fails to consider the partitioning of runoff in its estimation of available precipitation for recharge. The southern, monsoon-dominated basins tend to experience greater quick runoff during monsoon events, meaning that relatively less precipitation that occurs becomes recharge. Thus, the NSWI would overestimate summer recharge in those basins. Second, variation in the thickness of the vadose zone over the domain would indicate varying recharge lag times as water resides in the unsaturated zone (McMahon et al., 2006; Rossman et al., 2014), perhaps impacting partitioning of precipitation into evapotranspiration and recharge. Third, variation in vegetation rooting depths across the domain may cause a similar misestimation of ET using climatic data only. Arid and semi-arid zones have been shown to have some of the deepest rooting depths globally (Schenk and Jackson, 
2002\&2005), indicating that ET in Basin and Range systems likely occurs over a greater thickness in the vadose zone.

Finally, the correlation between scatter and precipitation seasonality could be owed to the recharge estimation method, as the Maxey-Eakin method was common to most of the low-scatter basins. However, when all three estimation methods were applied to all basins, the pattern of greater scatter in the more southern and more summer precipitation-dominated basins remained. The only major difference between the estimation methods when applied to all basins was in the annual recharge length. The Anderson equation greatly underestimated annual recharge in the Great Basin and Rio Grande Valley sites, while the Maxey-Eakin and Waltemeyer methods greatly overestimated recharge in the Arizona basins. Therefore, the difference in scatter between basis cannot be attributed solely to the different recharge estimation methods.

Any patterns in the correlation between NSWI and isotopically-scaled recharge as represented by best fit slope are not clear. For most sites, NSWI-scaled winter recharge tended to underestimate recharge compared to isotopically-scaled recharge (Figures 710). A few basins which exhibited low scatter and high correlation, but significant deviation in y-intercept, could be candidates for application of a shift function to improve NSWI estimates, including the Salt Lake Valley and Verde Valley. Similarly, a shift function could be developed for basins with low scatter and small deviation in yintercept, but low correlation, including central Nevada and the Mojave Desert.

Interestingly, the two basins with the greatest deviation in y-intercept from zero are the two basins located on the very edges of the Basin and Range Province, the Verde Valley and Sacramento Mountains (Figure 10). These basins and most others experienced 
a negative y-intercept. For basins with a slope less than 1, as most here experienced, this means that the NSWI-scaled winter recharge values tended to underestimate the isotopically-scaled values. This pattern is likely attributable to the lack of consideration of partitioning of precipitation into quick runoff in the NSWI estimation method.

In a future of shifting seasonality of precipitation and recharge, estimates of recharge seasonality based on observed climatic data could be incredibly useful for land surface modelers. The high correlation between isotopically- and NSWI-scaled winter recharge in some basins supports the use of NSWI-based seasonalization of recharge for parameterization of groundwater models, land surface partitioning models, and basin water budgets in those basins. Basins that experience significant quick runoff are not well-modeled using the NSWI, so a method that incorporated quick runoff could improve estimations of recharge seasonality in those basins.

\section{Recharge under future climate}

As the quantity and seasonality of precipitation changes in these basins with climate change, the relative contribution to recharge from mountain-system recharge and in-stream flood-driven recharge will change. Some studies have shown that rising temperatures are changing the timing and amount of spring snowmelt in the western U.S., leading to differences in the timing and quantity of diffuse recharge occurring in mountain-systems (Hamlet et al., 2005; Mote et al., 2005). As temperatures are predicted to rise across the region in the coming decades and winter precipitation in the Basin and Range is predicted to decrease, we might expect a shift in the recharge regimes in these basins toward greater contributions from summer convective event recharge (Seager et al., 2007; Solomon et al., 2007; Dominguez et al., 2012). 


\section{Predicted climate change}

The estimations of winter recharge fraction in these basins can be used to interpret how projected future climate change may propagate through the recharge processes, impacting future recharge timing and quantity. An ensemble of 24 global circulation models (GCMs) and GCM/regional climate model (RCM) combinations projected up to a $20 \%$ increase in winter precipitation in the northern Basin and Range, and a corresponding $20 \%$ decrease in winter precipitation in the southern Basin and Range with a high level of model agreement (Dominguez et al., 2012). At the same time, the frequency of extreme 50-year return winter precipitation events increased for both the north and the south. The GCMs used to generate future climate predictions have been less skillful in predicting the North American Monsoon (NAM) than for cool-season precipitation in the region (Castro et al., 2012).

Model projections indicate that warmer global temperatures could result in a weakened ENSO-monsoon connection (Solomon et al., 2007). An examination of 19 GCMs indicates an overall drying trend in the southwestern U.S., with precipitation decreasing $-0.1 \mathrm{~mm} /$ day to $-0.2 \mathrm{~mm} /$ day from 1900 to 2100 , and evapotranspiration decreasing about $-0.05 \mathrm{~mm} /$ day in the same period (Seager et al., 2007). The models also indicated a northward expansion of the southwestern US arid subtropical zone as rising Pacific SSTs push the Westerlies further north. Greater humidity due to higher temperatures was shown to increase divergence of moisture, causing dry regions to become drier and wet regions wetter.

Comparison of two major droughts in the southwestern US in the 1950s and 2000s showed that higher daily minimum and maximum temperatures led to increased evapotranspirational demand (and less precipitation) in most parts of the region during 
the late summer monsoon season (Weiss et al., 2009). In the 2000s drought, however, evapotranspirational demand did not increase during the monsoon season in the core of the monsoon, where higher dewpoint temperatures compensated for higher air temperatures. In light of climate projections of increasingly higher temperatures in the region in the future, evapotranspirational demand is expected to increase during the monsoon season, leading to less availability of precipitation for recharge and less soil moisture (IPCC, 2014).

\section{Climate change impacts to recharge}

The picture of a generally drier southern Basin and Range emerges from these climate projections, and particularly drier in the winter. Because winter recharge plays a disproportionately large role in total annual recharge in the southern Basin and Range, this would suggest a general future decrease in total annual recharge. How the seasonality of recharge in the south might be affected is less clear, as any future changes in NAM precipitation and summer evaporative demand are less clear. An increase in NAM precipitation may lead to a smaller increase in summer recharge. A higher summer evaporative demand would diminish that increase, but still the seasonality of recharge would move toward greater contribution from summer recharge. A decrease in NAM precipitation may lead to a decrease in summer recharge, and a small decrease in total annual recharge, with little impact on the seasonality of recharge as both winter and summer precipitation decrease.

In the northern Basin and Range, projected increased winter precipitation would lead to increased total annual recharge, as winter precipitation is shown here to compose the great majority of recharge in the north. Similarly, a region-wide drying trend would decrease total annual recharge in the north. The possibility of an intensified NAM could 
bring more intense summer precipitation to northern reaches of the Basin and Range, increasing total annual recharge. If winter precipitation does not increase at the same time as summer precipitation, recharge seasonality in the north may shift toward a greater contribution of summer recharge to total annual recharge. Meanwhile, any increases in evapotranspirational demand associated with warming would lead to decreased winter and total annual recharge in the north.

\section{CONCLUSIONS}

There are clear spatial trends in the seasonality of recharge across the Basin and Range Province as indicated by stable water isotope signatures of precipitation and groundwater. Across the region, recharge is dominated by winter precipitation, even in southern basins where the majority of annual precipitation occurs in the summer. The marked difference between the timing of precipitation and the timing of recharge in the southern Basin and Range illustrates the weak impact of the NAM on recharge in the region. The NSWI does well in estimating recharge seasonality for some basins, primarily in the northern Basin and Range and in basins without significant quick runoff from summer precipitation events. Future climate projections for the region vary and would have varying impacts on the seasonality and quantity of annual recharge.

\section{ACKNOWLEDGMENTS}

This paper was developed under STAR Fellowship Assistance Agreement no. FP91749101-0 awarded by the U.S. Environmental Protection Agency (EPA). It has not been formally reviewed by EPA. The views expressed in this paper are solely those of Kirstin L. Neff, and EPA does not endorse any products or commercial services mentioned in this paper. This work was supported in part by a NSF Dynamics of Coupled Human-Natural Systems grant (DEB-1010495). 
Special thanks to the members of the USGS John Wesley Powell Center Working Group on Western North America Groundwater Recharge, whose collaboration has been instrumental in developing this research. 


\section{REFERENCES}

Abdulaziz AM, Hurtado JM, Faid A. 2012. Hydrogeological characterization of Gold Valley: an investigation of precipitation recharge in an intermountain basin in the Death Valley region, California, USA. Hydrogeology Journal 20(4): 701-718.

Ajami H, Meixner T, Dominguez F, Hogan JF, Maddock III T. 2012. Seasonalizing mountain system recharge in semi-arid basins--climate change impacts. Ground Water 50(4): 585-597.

Ajami H, Troch PA, Maddock III T, Meixner T, Eastoe C. 2011. Quantifying mountainblock recharge by means of catchment-scale storage-discharge relationships, Water Resources Research 47: W04504, DOI: 10.1029/2010WR009598.

Anderson K, Nelson S, Mayo A, Tingey D. 2006. Interbasin flow revisited: the contribution of local recharge to high-discharge springs, Death Valley, CA. Journal of Hydrology 323: 276-302. DOI:10.1016/j.jhydrol.2005.09.004.

Anderson TW, Freethey GW, Tucci P. 1992. Geohydrology and water resources of alluvial basins in South-Central Arizona and parts of adjacent states, USGS Professional Paper 1406-B.

Baillie MN, Hogan JF, Ekwurzel B, Wahi AK, Eastoe CJ. 2007. Quantifying water sources to a semi-arid riparian ecosystem, San Pedro River, Arizona. Journal of Geophysical Research 112, G03S02, DOI:10.1029/2006JG000263.

Blasch KW, Bryson JR. 2007. Distinguishing sources of ground water recharge by using $\delta \mathrm{D}$ and $\delta^{18} \mathrm{O}$. Ground Water 45(3): 293-308. DOI: 10.1111/j.1745-6584.2006.00289.x.

Blasch KW, Hoffmann JP, Graser LF, Bryson JR, Flint AL. 2005. Hydrogeology of the Upper and Middle Verde River watersheds, central Arizona: U.S. Geological Survey Scientific Investigations Report 2005-5198, 102 pp., 3 plates.

Bukovsky MS, Gochis DJ, Mearns LO. 2013. Towards assessing NARCCAP regional climate model credibility for the North American Monsoon: current climate simulations. Journal of Climate 26: 8802-8826.

Camargo SJ, Robertson AW, Barnston AG, Ghil M. 2008. Clustering of eastern North Pacific tropical cyclone tracks: ENSO and MJO effects. Geochemistry Geophysics Geosystems 9(6). 23pp. DOI:10.1029/2007GC001861.

Castro CL, Chang H, Dominguez F, Carillo C, Schemm J, Juang HH. 2012. Can a regional climate model improve the ability to forecast the North American Monsoon? Journal of Climate 25: 8212-8237.

Cayan DR, Webb RH. 1992. El Nino/Southern Oscillation and streamflow in the western United States, in El Nino, historical and paleoclimatic aspects of the Southern 
Oscillation, edited by Diaz HF, Markgraf V. Cambridge University Press, Cambridge, pp. 29-68.

Clark ID, Fritz P. 1997. Environmental Isotopes in Hydrogeology. CRC Press: New York. 328pp.

Cook BI, Ault TR, Smerdon JE. 2015. Unprecedented $21^{\text {st }}$ century drought risk in the American Southwest and Central Plains. Science Advances 1(1). doi: http://dx.DOI.org/10.1126/sciadv.1400082.

Craig H. 1961a. Standard for reporting concentrations of deuterium and oxygen-18 in natural waters. Science 133(3467): 1833-1834.

Craig H. 1961b. Variations in meteoric waters. Science 133(3465): 1702-1703.

de Vries JJ, Simmers I. 2002. Groundwater recharge: an overview of processes and challenges. Hydrogeo J 10: 5-17.

Dansgaard W. 1964. Stable isotopes in precipitation. Tellus 16(4): 436-468.

Dickinson JE, Hanson TR, Ferré TPA, Leake SA. 2004. Inferring time-varying recharge from inverse analysis of long-term water levels. Water Resources Research 40, W07403, DOI:10.1029/2003WR002650.

Dominguez F, Rivera E, Lettenmaier DP, Castro CL. 2012. Changes in winter precipitation extremes for the western United States under a warmer climate as simulated by regional climate models, Geophysical Research Letters. DOI:

10.1029/2011GL050762.

Dominguez F, Villegas JC, Breshears DD. 2009. Spatial extent of the North American Monsoon: Increased crossregional linkages via atmospheric pathways. Geophysical Research Letters 36: L07401. DOI:10.1029/2008GL037012.

Druhan JL, Hogan JF, Eastoe CJ, Hibbs BJ, Hutchison WR. 2008. Hydrogeologic controls on groundwater recharge and salinization: a geochemical analysis of the northern Hueco Bolson aquifer, Texas, USA. Hydrogeology Journal 16: 281-296. DOI: DOI 10.1007/s10040-007-0222-9.

Earman S, Campbell AR, Phillips FM, Newman BD. 2006. Isotopic exchange between snow and atmospheric water vapor: estimation of the snowmelt component of groundwater recharge in the southwestern United States. Journal of Geophysical Research 111. D09302, doi:10.1029/2005JD006470.

Earman S, Dettinger M. 2011. Potential impacts of climate change on groundwater resources - a global review. Journal of Water and Climate Change 2(4): 213-229. doi: 10.2166/wcc.2011.034. 
Eastoe CJ, Gu A, Long A. 2004. The origins, ages and flow paths of groundwater in Tucson Basin: results of a study of multiple isotope systems. In Groundwater Recharge in a Desert Environment: the Southwestern United States, edited by Hogan JF, Phillips FM, Scanlon BR. American Geophysical Union: Washington, D.C.: 217-234.

Eastoe CJ, Hibbs BJ, Olivas A, Hogan JF, Hawley J, Hutchison WR. 2008. Isotopes in the Hueco Bolson aquifer, Texas (USA) and Chihuahua (Mexico): local and general implications for recharge sources in alluvial basins. Hydrogeology Journal 16(4): 737 747.

Eastoe CJ, Rodney R. 2014. Isotopes as tracers of water origin in and near a regional carbonate aquifer: The southern Sacramento Mountains, New Mexico. Water 6: 301-323. doi:10.3390/w6020301.

Famiglietti JS. 2014. The global groundwater crisis. Nature Climate Change 4: 945-948.

Friedman I, Smith GI, Johnson CA, Moscati RJ. 2002. Stable isotope compositions of waters in the Great Basin, United States: 2. Modern precipitation. Journal of Geophysical Research 107(D19), 4401, DOI: 10.1029/2001JD000566.

Genereux DP, Hooper RP. 1998. Oxygen and hydrogen isotopes in rainfall-runoff studies, in Isotope Tracers in Catchment Hydrology, eds. C. Kendall and Journal McDonnell, chap. 10, pp. 319-346, Elsevier Sci., Amsterdam.

Griffin D, Woodhouse CA, Meko DM, Stahle DW, Faulstich HL, Carillo C, Touchan R, Castro CL, Leavitt SW. 2013. North American monsoon precipitation reconstructed from tree-ring latewood. Geophysical Research Letters 40: 954-957.

Hales Jr. JR. 1974. Southwestern United States summer monsoon source: Gulf of Mexico or Pacific Ocean? Journal of Applied Meteorology 13: 331-342.

Hamlet AF, Mote PW, Clark MP, Lettenmaier DP. 2005. Effects of temperature and precipitation variability on snowpack trends in the western United States, Journal of Climate 18(21): 4545-4561.

Hogan JF, Phillips FM, Scanlon BR. 2004. Groundwater Recharge in a Desert Environment. American Geophysical Union: Washington, D.C. 294 pp.

Hu H, Dominguez F. 2015. Evaluation of oceanic and terrestrial sources of moisture for the North American Monsoon using numerical models and precipitation stable isotopes. Journal of Hydrometeorology 16: 19-35. DOI: 10.1175/JHM-D-14-0073.1.

IPCC, 2014: Climate Change 2014: Impacts, Adaptation, and Vulnerability. Part B: Regional Aspects. Contribution of Working Group II to the Fifth Assessment Report of the Intergovernmental Panel on Climate Change [Barros VR, Field CB, Dokken DJ, Mastrandrea MD, Mach KJ, Bilir TE, Chatterjee M, Ebi KL, Estrada YO, Genova RC, Girma B, Kissel ES, Levy AN, MacCracken S, Mastrandrea PR, White LL (eds.)]. 
Cambridge University Press, Cambridge, United Kingdom and New York, NY, USA, $688 \mathrm{pp}$.

Izbicki JA, Radyk J, Michel RL. 2000. Water movement through a thick unsaturated zone underlying an intermittent stream in the western Mojave Desert, southern California. $J$ Hydrology 238: 194-217.

Jasechko S, Birks SJ, Gleeson T, Wada Y, Fawcett PJ, Sharp ZD, McDonnell JJ, Welker JM. 2014. The pronounced seasonality of global groundwater recharge. Water Resources Research 50: 8845-8867, doi:10.1002/2014WR015809.

Kalin RM. 1994. The hydrogeochemical evolution of the groundwater of the Tucson basin with application to 3-dimensional groundwater flow modeling. Ph.D. dissertation, University of Arizona, $550 \mathrm{pp}$.

Kendall C, Coplen TB. 2001. Distribution of oxygen-18 and deuterium in river waters across the United States. Hydrological Processes 15: 1363-1393. doi: 10.1002/hyp. 217.

Lechler AR, Niemi NA. 2011. Controls on the spatial variability of modern meteoric $\delta^{18} \mathrm{O}$ : empirical restrains from the western US and East Asia and implications for stable isotope studies. American Journal of Science 311: 664-700.

Leenhouts JM, Stromberg JC, Scott RL. 2006. Hydrologic requirements of and consumptive ground-water use by riparian vegetation along the San Pedro River, Arizona. U. S. Geological Survey, Scientific Investigations Report 2005-5163.

Lyle M, Heusser L, Ravelo C, Yamamoto M, Barron J, Diffenbaugh NS, Herbert T, Andreasen D. 2012. Out of the tropics: the Pacific, Great Basin Lakes, and the Pleistocene water cycle in the western United States. Science 337: 1629-1633.

Manning AH. 2011. Mountain-block recharge, present and past, in the eastern Española Basin, New Mexico, USA. Hydrogeology Journal 19: 379-397.

Manning, AH, Solomon DK. 2005. An integrated environmental tracer approach to characterizing groundwater circulation in a mountain block. Water Resources Research 41, W12412, doi:10.1029/2005WR004178.

Maxey GB, Eakin TE. 1949. Ground water in White River Valley, White Pine, Nye, and Lincoln Counties, Nevada, Water Resources Bulletin No. 8, Nevada State Engineer, 59p.

McMahon PB, Dennehy KF, Bruce BW, Bohlke JK, Michel RL, Gurdak JJ, Hurlburt DB. 2006. Storage and transit time of chemicals in thick unsaturated zones under rangeland and irrigated cropland, High Plains, United States. Water Resources Research 42 (W03413): 1-18.

McMahon PB, Plummer LN, Bohlke JK, Shapiro SD, Hinkle SR. 2011. A comparison of recharge rates in aquifers of the United States based on groundwater-age data.

Hydrogeology Journal 19: 779-800. 
McPhee J. 1980. Basin and Range. New York, NY: Farrar, Straus, and Giroux. 216pp.

Mote PW, Hamlet AF, Clark MP, Lettenmaier DP. 2005. Declining mountain snowpack in western North America. Bulletin of the American Meteorological Society 86(1): 39-44.

Neff KL. 2014a. IsoMAP job 44200, Isoscapes Modeling, Analysis and Prediction (version 1.0). The IsoMAP Project. http://isomap.org.

Neff KL. 2014b. IsoMAP job 44201, Isoscapes Modeling, Analysis and Prediction (version 1.0). The IsoMAP Project. http://isomap.org.

Neff KL. 2015a. IsoMAP job 45422, Isoscapes Modeling, Analysis and Prediction (version 1.0). The IsoMAP Project. http://isomap.org.

Neff KL. 2015b. IsoMAP job 45423, Isoscapes Modeling, Analysis and Prediction (version 1.0). The IsoMAP Project. http://isomap.org.

Neff KL, de la Cruz L, Meixner T, Medina MR, Taylor A, Pineda C, Grijalva I. Climate and geographic controls on groundwater recharge and baseflow: a geochemical analysis of the Río San Miguel Basin, Sonora, Mexico. In-prep.

Newton T, Timmons S, Rawling G, Partey F, Kludt T, Land L, Timmons M, Walsh P. 2009. Sacramento Mountains Hydrogeology Study: Progress Report October 2009. New Mexico Bureau of Geology and Mineral Resources, Open File Report 518. 70pp.

Nguyen U, Glenn EP, Nagler PL, Scott RL. 2014. Long-term decrease in satellite vegetation indices in response to environmental variables in an iconic desert riparian ecosystem: the Upper San Pedro, Arizona, United States. Ecohydrology. DOI: 10.1002/eco.1529.

Rose TP, Kersting AB, Harris LJ, Hudson GB, Smith DK, Williams RW, Loewen DR, Nelson EJ, Allen PG, Ryerson FJ, Pawloski GA, Laue CA, Moran JE. 2003. Stable Isotope Investigation of Precipitation and Recharge Processes in Central Nevada. In Hydrologic Resources Management Program and Underground Test Area Project, 20012002 Progress Report. 113-134.

Rossman NR, Zlotnik VA, Rowe CM, Szilagyi, J. 2014. Vadose zone lag time and potential $21^{\text {st }}$ century climate change effects on spatially distributed groundwater recharge in the semi-arid Nebraska Sand Hills. Journal of Hydrology 529: 656-669.

Schenk HJ, Jackson RB. 2002. The global biogeography of roots. Ecological Monographs 72(3): 311-328.

Schenk HJ, Jackson RB. 2005. Mapping the global distribution of deep roots in relation to climate and soil characteristics. Geoderma 126: 129-140.

doi:10.1016/j.geoderma.2004.11.018. 
Seager R, Ting M, Held IEA. 2007. Model projections of an imminent transition to a more arid climate in southwestern North America. Science 5828: 1181-1184.

Serrat-Capdevila A, Valdés JB, Dominguez F, Rajagopal S. 2013. Characterizing the water extremes of the new century in the US Southwest: a comprehensive assessment from state-of-the-art climate model projections. International Journal of Water Resources Development 29(2): 152-171. DOI: 10.1080/07900627.2012.721717.

Serrat-Capdevila A., Valdés JB, Pérez JG, Baird K, Mata LJ, Maddock III T. 2007. Modeling climate change impacts--and uncertainty--on the hydrology of a riparian system: The San Pedro Basin (Arizona/Sonora). Journal of Hydrology 347(1-2), 48-66.

Simpson ES, Thorud DB, Friedman I. 1972. Distinguishing seasonal recharge to groundwater by deuterium analysis in southern Arizona. In World Water Balance, Proceedings of the 1970 Reading Symposium, International Association of Scientific Hydrology. UNESCO-WMO; 623-633.

Simpson SC, Meixner T, Hogan JF. 2013. The role of flood size and duration on streamflow and riparian groundwater composition in a semi-arid basin. Journal of Hydrology 488: 126-135.

Solomon S, Qin D, Manning M, Chen Z, Marquis M, Averyt KB, Tignor M, Miller H (eds). 2007. The physical science basis: Contribution of working group I to the fourth assessment report of the intergovernmental panel on climate change. Cambridge University Press, Cambridge, U.K.

Stonestrom DA, Prudic DE, Laczniak RJ, Akstin KC. 2004. Tectonic, climatic, and landuse controls on groundwater recharge in an arid alluvial basin: Amargosa Desert, U.S.A. In Groundwater Recharge in a Desert Environment: the Southwestern United States, Hogan JF, Phillips FM, Scanlon BR (eds.). American Geophysical Union: Washington D.C.; $29-48$.

Stromberg JC, Tiller R, Richter B. 1996. Effects of groundwater decline on riparian vegetation of semi-arid regions: The San Pedro, Arizona. Ecological Applications 6(1): 113-131.

Thiros SA, Manning AH. 2004. Quality and sources of ground water used for public supply in Salt Lake Valley, Salt Lake County, Utah, 2001. U.S. Geol. Surv. Water Resour. Invest. Rep., 03-4325; 95.

U.S. Geological Survey. 2014. National Water Information System data available on the World Wide Web (Water Data for the Nation), accessed April 2, 2014, at http://waterdata.usgs.gov/nwis/.

Vivoni ER, Bowman RS, Wyckoff RL, Jakubowski RT, Richards KE. 2006. Analysis of a monsoon flood event in an ephemeral tributary and its downstream hydrologic effects. Water Resources Research 42(3): W03404, DOI: 10.1029/2005WR004036. 
Wahi AK, Hogan JF, Ekwurzel B, Baillie MN, Eastoe CJ. 2008. Geochemical quantification of semi-arid mountain recharge. Ground Water 46(3): 414-425.

Waltemeyer SD. 2001. Estimates of mountain-front streamflow available for potential recharge to the Tularosa Basin, New Mexico, USGS Water-Resources Investigations Report 01-4013, 8p.

Weiss JL, Castro CL, Overpeck JT. 2009. Distinguishing pronounced droughts in the southwestern United States: seasonality and effects of warmer temperatures. Journal of Climate 22: 5918-5932.

Wernicke B. 1981. Low-angle normal faults in the Basin and Range Province: nappe tectonics in an extending orogen. Nature 291: 645-648.

Wilson JL, Guan H. 2004. Mountain-block hydrology and mountain-front recharge. In Groundwater Recharge in a Desert Environment: the Southwestern United States, Hogan JF, Phillips FM, Scanlon BR (eds.). American Geophysical Union: Washington D.C.; 113-137.

Winograd IJ, Riggs AC, Coplen TB. 1998. The relative contributions of summer and cool-season precipitation to groundwater recharge, Spring Mountains, Nevada, USA. Hydrogeology Journal 6(1): 77-93.

Winograd IJ, Landwehr JM, Coplen TB, Sharp WD, Riggs AC, Ludwig KR, Kolesar PT. 2006. Devils Hole, Nevada, $\delta^{18} \mathrm{O}$ record extended to the mid-Holocene, Quarternary Research 66: 202-212.

Western Regional Climate Center (WRCC). 2015. Cooperative Climatological Data Summaries. Accessed March 13, 2015 at http://www.wrcc.dri.edu/climatedata/climsum/.

Witcher JC, King JP, Hawley JW, Kennedy JF, Williams J, Cleary M, Bothern L (2004) Sources of Salinity in the Río Grande and Mesilla Basin Groundwater. New Mexico Water Resources Research Institute Technical Completion Report No. 330, New Mexico State University, Las Cruces, NM, 183 pp

Wright WE. 2001. $\delta \mathrm{D}$ and $\delta^{18} \mathrm{O}$ in mixed conifer systems in the U.S. Southwest: The potential of $\mathrm{d} 18 \mathrm{O}$ in Pinus Ponderosa tree rings as a natural environmental recorder. Ph.D. thesis, Department of Geosciences, University of Arizona, Tucson, Arizona. 


\section{TABLES}

Table 1. Metadata for isotopic data sources

\begin{tabular}{|c|c|c|c|c|}
\hline Basin & $\begin{array}{c}\# \\
\text { Samples }\end{array}$ & $\begin{array}{l}\text { Collection } \\
\text { Timeframe }\end{array}$ & Definition of seasons & Reference \\
\hline Salt Lake Valley & 67 & $1990-2001$ & Not defined & $\begin{array}{l}\text { Friedman et al., 2002; } \\
\text { Thiros and Manning } \\
2004\end{array}$ \\
\hline Carson Valley (NV) & 27 & 1979-2011 & S: Aug-Nov; W: Mar-May & NWIS 2014 \\
\hline Central NV & 64 & $1999-2002$ & S: Jun-Sep; W: Oct-May & Rose et al., 2003 \\
\hline Spring Mtns (NV) & 179 & $1975-1988$ & S: Jul-Sep; W: & Winograd et al., 1998 \\
\hline Verde (AZ) & $>100$ & $7 / 2003-8 / 2004$ & $\begin{array}{l}\text { S: Jul-Sep; F: Oct-Nov; } \\
\text { W: Dec-Mar }\end{array}$ & $\begin{array}{l}\text { Blasch and Bryson 2007; } \\
\text { Blasch et al., } 2005\end{array}$ \\
\hline Mojave (CA) & 50 & 1994-1998 & S: May-Nov; W: Dec-Apr & Izbicki et al., 2000 \\
\hline Sacramento Mtns (NM) & $>100$ & 2006-2009 & S: Apr-Sep; W: Oct-Mar & Newton et al., 2009 \\
\hline Tucson (AZ) & $>500$ & $\begin{array}{l}\text { T: } 1981-2000 \\
\text { P: } 1995-2000 \\
\end{array}$ & S: May-Sep; W: Oct-Apr & $\begin{array}{l}\text { Kalin, 1994; Wright, } \\
2001\end{array}$ \\
\hline Hueco Bolson (TX) & $>180$ & $\begin{array}{l}\text { GW: } 2002-3 \\
\text { P: 2004-5 }\end{array}$ & $\begin{array}{l}\text { Four seasons }(\mathrm{Sp}, \mathrm{Su}, \mathrm{F}, \mathrm{W}) \\
\text { monthly ranges not reported }\end{array}$ & $\begin{array}{l}\text { Witcher et al., 2004; } \\
\text { Druhan et al., 2008; } \\
\text { Eastoe et al., 2008 }\end{array}$ \\
\hline San Pedro (AZ) & 89 & $2003-2005$ & S: Apr-Sep; W: Oct-Mar & Wahi et al., 2008 \\
\hline San Miguel (MX) & 78 & $2005-2012$ & S: Apr-Sep; W: Oct-Mar & Neff et al., 2015 \\
\hline
\end{tabular}

Table 2. Scaling factors for Maxey-Eakin method of recharge estimation

\begin{tabular}{|c|c|}
\hline Precipitation (in) & $\boldsymbol{a}_{\boldsymbol{i}}$ \\
\hline$<8$ & 0.00 \\
\hline $8-12$ & 0.03 \\
\hline $12-15$ & 0.07 \\
\hline $15-20$ & 0.15 \\
\hline$>20$ & 0.25 \\
\hline
\end{tabular}

Table 3. Suite of nine solutions applied to each set of endmembers (both $\delta^{18} \mathrm{O}$ and $\delta D$ ) to determine the isotopespecific and overall estimates of fraction winter recharge.

\begin{tabular}{|c|c|c|c|}
\hline \multicolumn{1}{|c|}{ Delta } & $\overline{\boldsymbol{\delta}}_{\boldsymbol{g} \boldsymbol{w}}$ & $\overline{\boldsymbol{\delta}}_{\boldsymbol{g w}}+\boldsymbol{\sigma}$ & $\overline{\boldsymbol{\delta}}_{\boldsymbol{g} \boldsymbol{w}}-\boldsymbol{\sigma}$ \\
\hline$\overline{\boldsymbol{\delta}}_{\boldsymbol{P}}$ & $f_{w}=\frac{\left(g w-P_{s}\right)}{\left(P_{w}-P_{s}\right)}$ & $f_{w}=\frac{\left((g w+\sigma)-P_{s}\right)}{\left(P_{w}-P_{s}\right)}$ & $f_{w}=\frac{\left((g w-\sigma)-P_{s}\right)}{\left(P_{w}-P_{s}\right)}$ \\
\hline$\overline{\boldsymbol{\delta}}_{\boldsymbol{P}}+\boldsymbol{\sigma}$ & $f_{w}=\frac{\left(g w-\left(P_{s}+\sigma\right)\right)}{\left(\left(P_{w}+\sigma\right)-\left(P_{s}+\sigma\right)\right)}$ & $f_{w}=\frac{\left((g w+\sigma)-\left(P_{s}+\sigma\right)\right)}{\left(\left(P_{w}+\sigma\right)-\left(P_{s}+\sigma\right)\right)}$ & $f_{w}=\frac{\left((g w-\sigma)-\left(P_{s}+\sigma\right)\right)}{\left(\left(P_{w}+\sigma\right)-\left(P_{s}+\sigma\right)\right)}$ \\
\hline$\overline{\boldsymbol{\delta}}_{\boldsymbol{P}}-\boldsymbol{\sigma}$ & $f_{w}=\frac{\left(g w-\left(P_{s}-\sigma\right)\right)}{\left(\left(P_{w}-\sigma\right)-\left(P_{s}-\sigma\right)\right)}$ & $f_{w}=\frac{\left((g w+\sigma)-\left(P_{s}-\sigma\right)\right)}{\left(\left(P_{w}-\sigma\right)-\left(P_{s}-\sigma\right)\right)}$ & $f_{w}=\frac{\left((g w-\sigma)-\left(P_{s}-\sigma\right)\right)}{\left(\left(P_{w}-\sigma\right)-\left(P_{s}-\sigma\right)\right)}$ \\
\hline
\end{tabular}




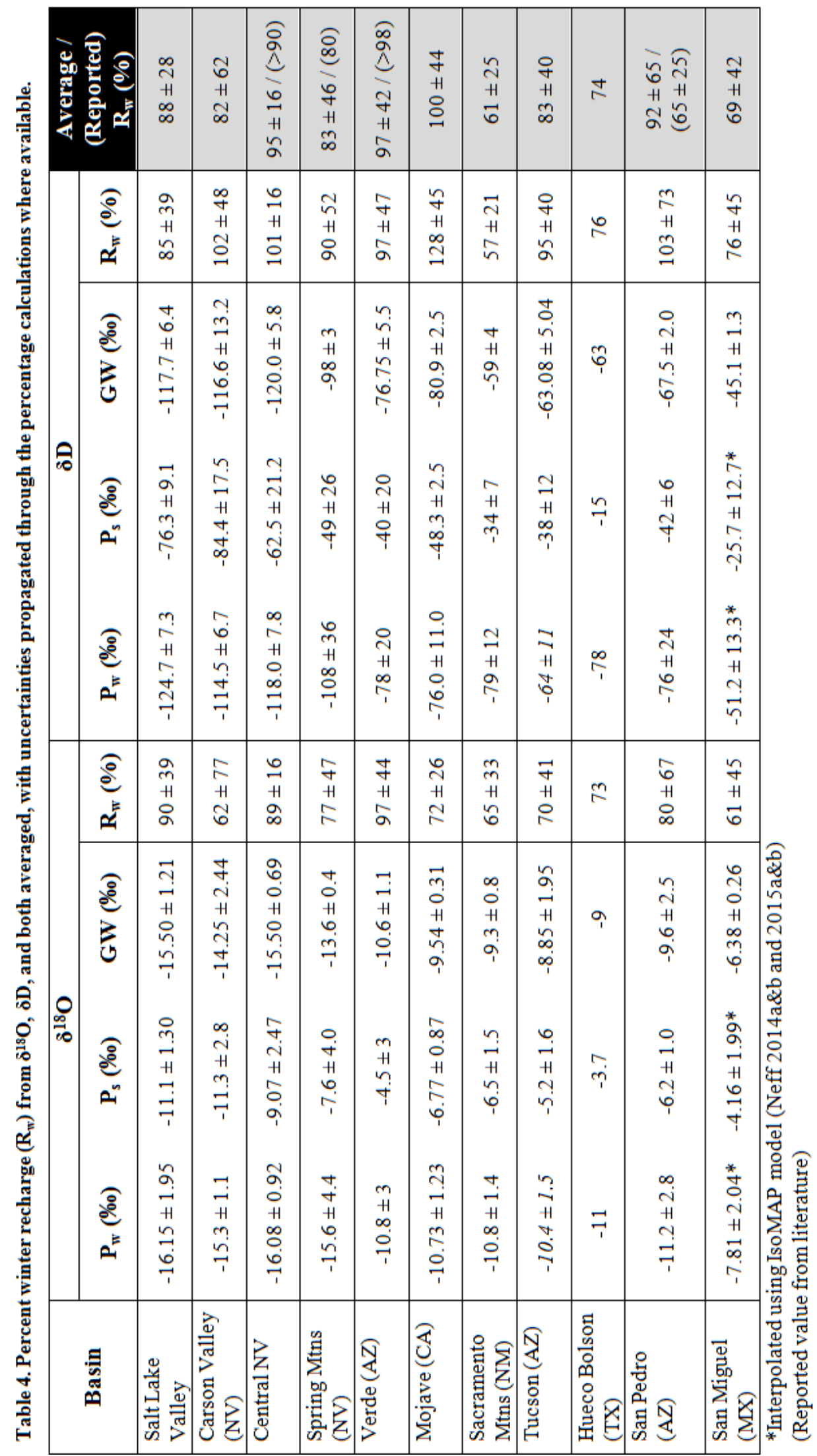




\section{FIGURES}

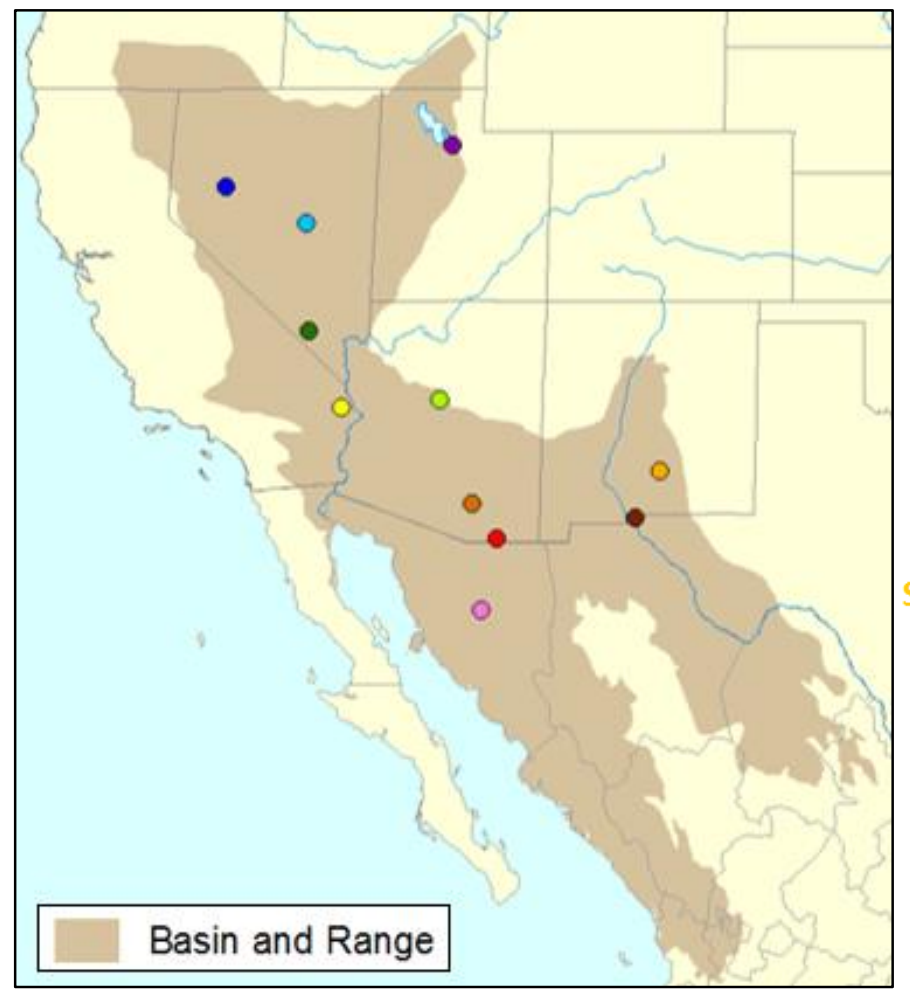

$$
\begin{array}{r}
\text { Salt Lake Valley } \\
\text { Carson Valley } \\
\text { Central Nevada } \\
\text { Spring Mtns } \\
\text { Verde }
\end{array}
$$

Mojave Desert

Sacramento Mtns

Tucson Basin

San Pedro

Hueco Bolson

San Miguel

Figure 1. Location of the Basin and Range Geological Province and study basins.

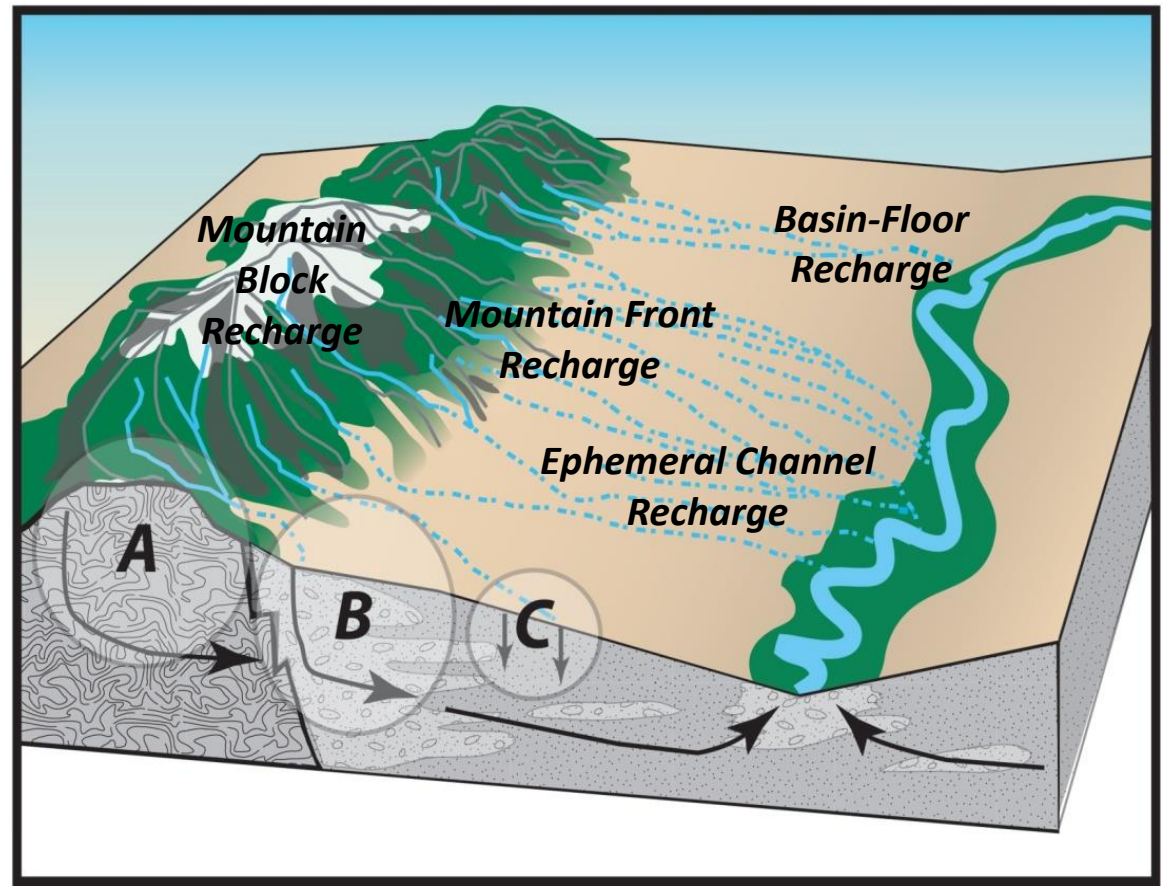

Figure 2. Conceptual model of recharge pathways in Basin and Range aquifers 


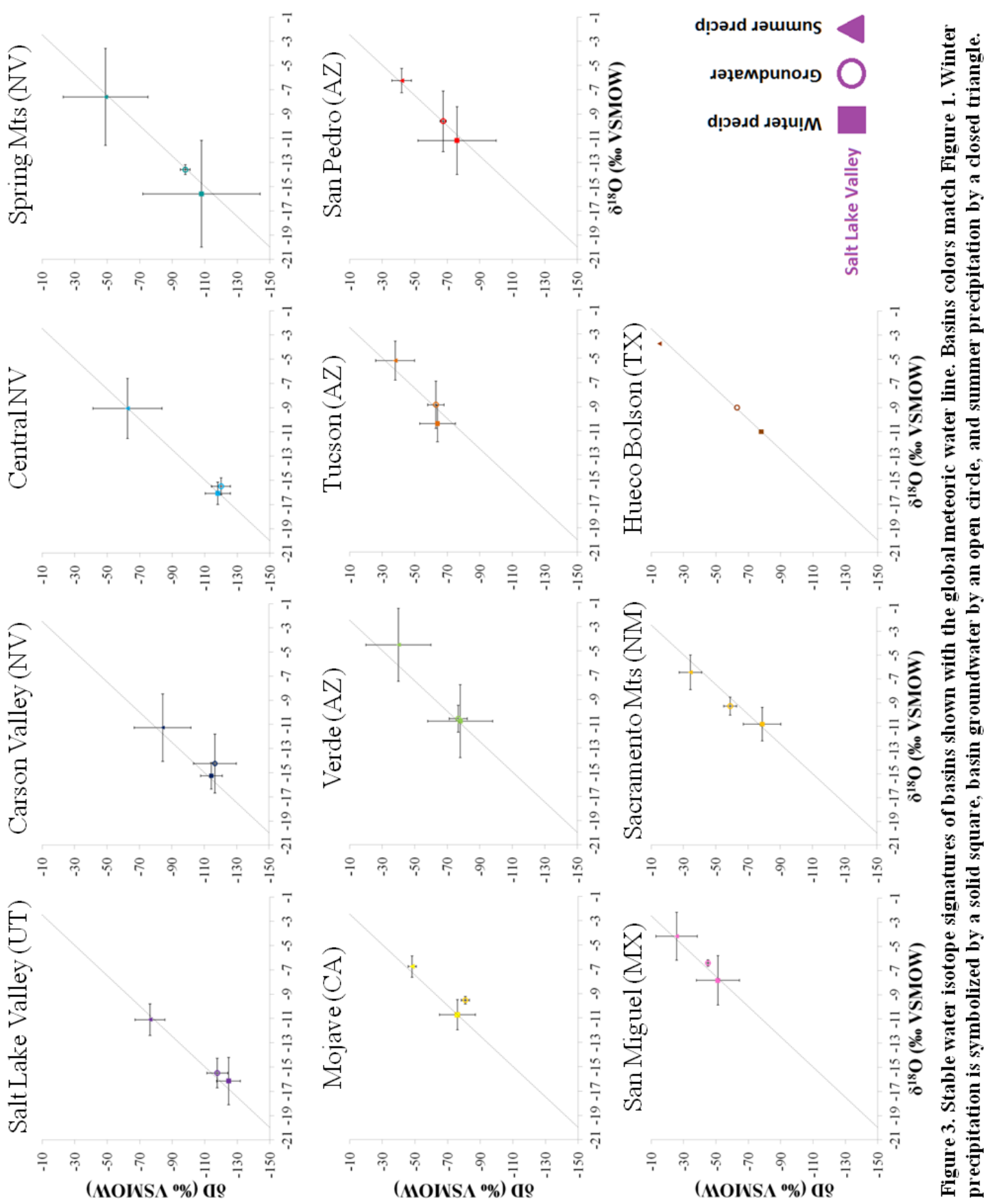


a)

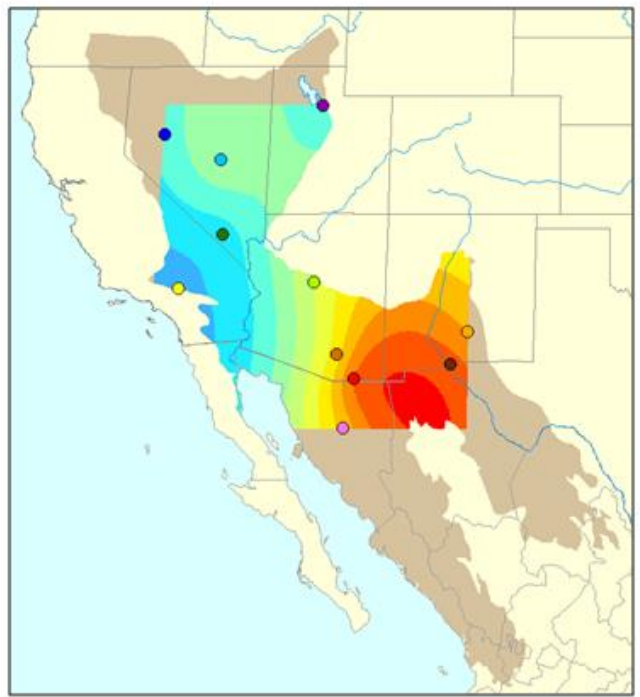

b)

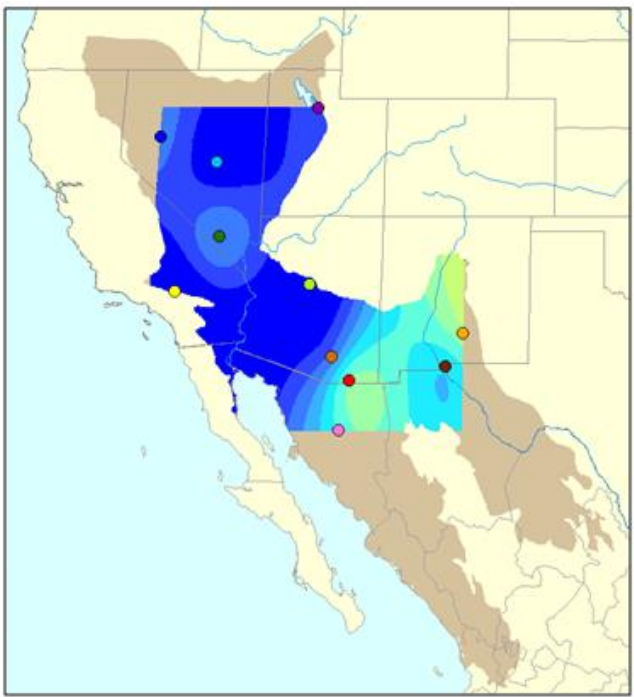

Fraction

$<0.3$

$0.3-0.35$

$0.35-0.4$

$0.4-0.45$

$0.45-0.5$

$0.5-0.55$

$0.55-0.6$

$0.6-0.65$

$0.65-0.7$

$0.7-0.75$

$0.75-0.8$

$0.8-0.85$

$0.85-0.9$

$0.9-0.95$

Figure 4. Interpolations from basin values for the fraction of (a) annual precipitation that occurs in winter from Western Regional Climate Center mean monthly data; and (b) annual recharge that occurs in winter based on analysis of stable water isotopes of winter precipitation, summer precipitation, and groundwater.

a)

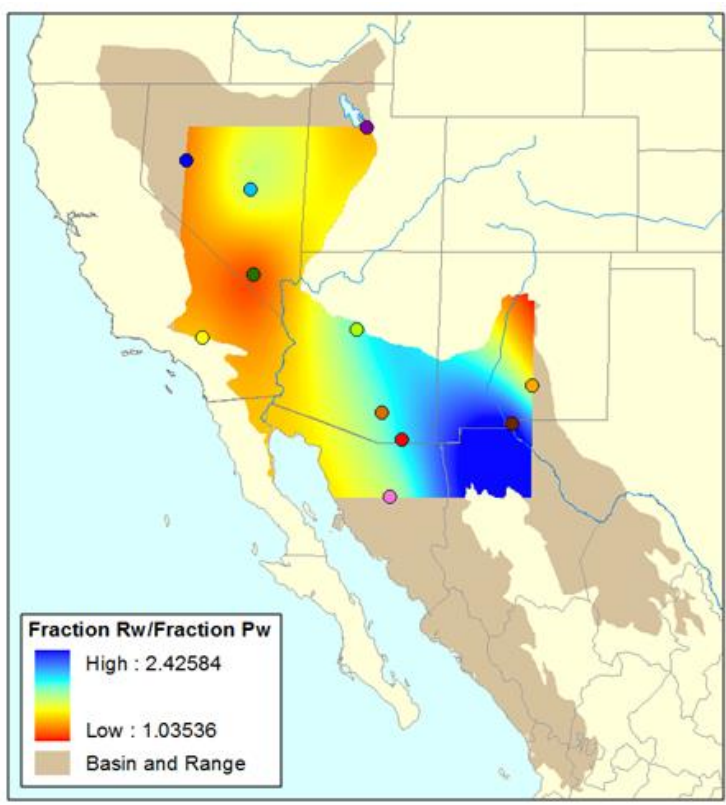

b)

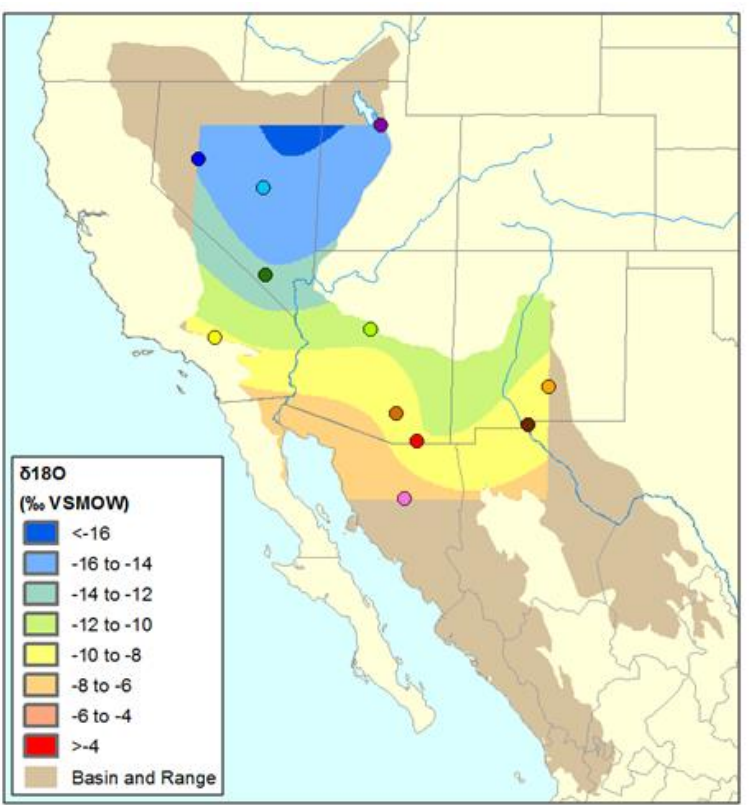

Figure 5. Spline interpolations of basin data for (a) the ratio of winter recharge fraction to winter precipitation fraction $(f \mathrm{Rw} / f \mathrm{Pw})$. Bluer areas feature a more disproportionate contribution of winter recharge as compared to winter precipitation; and (b) $\delta^{18} \mathrm{O}$ of mean groundwater across the Basin and Range. 
a)

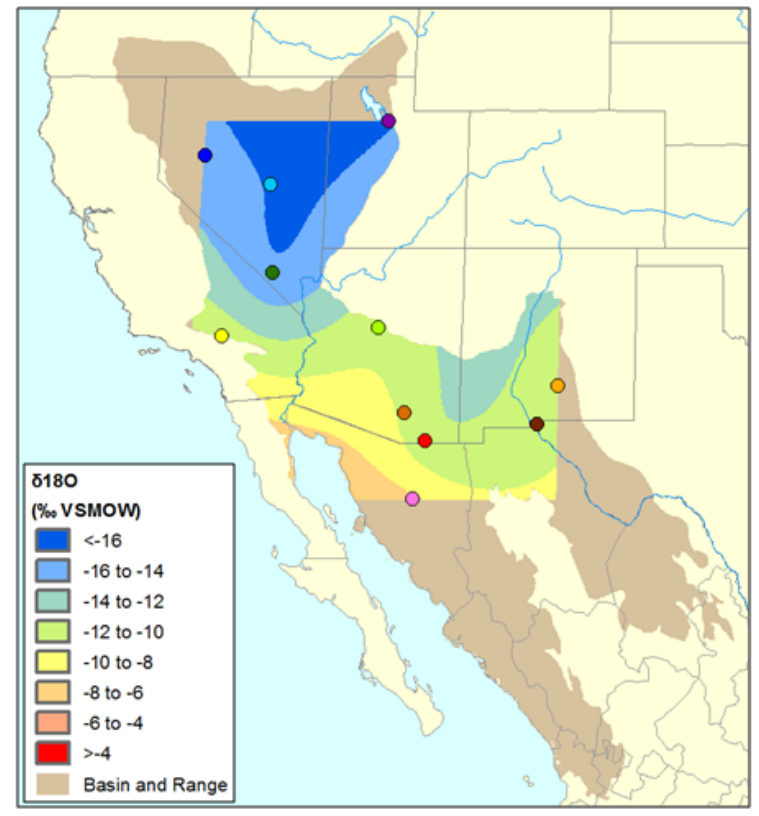

b)

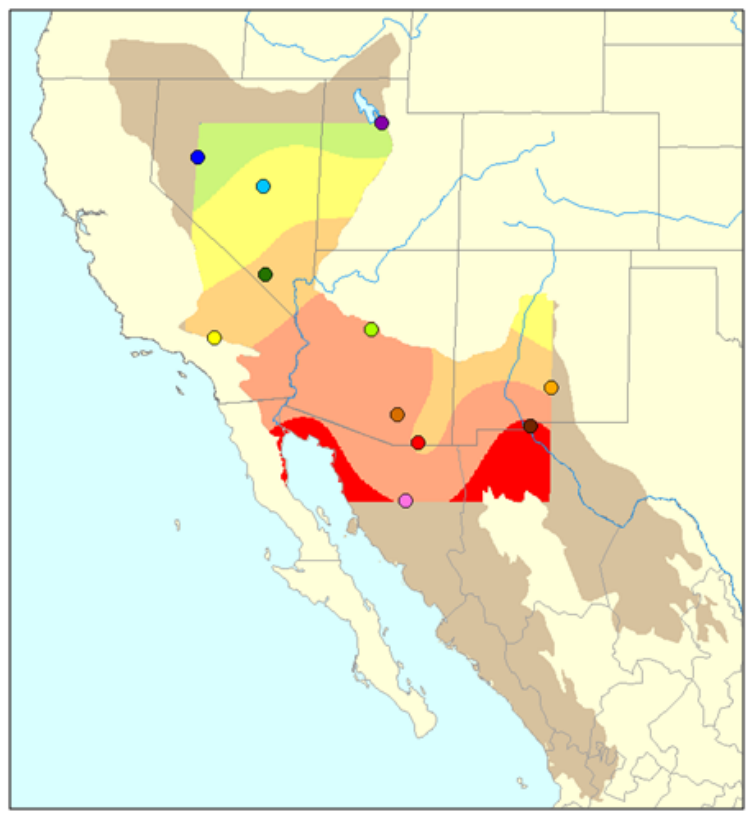

Figure 6. Spline interpolations created from basin data points of (a) $\delta^{18} \mathrm{O}$ of bulk winter precipitation; and (b) $\delta^{18} \mathrm{O}$ of bulk summer precipitation.

a)

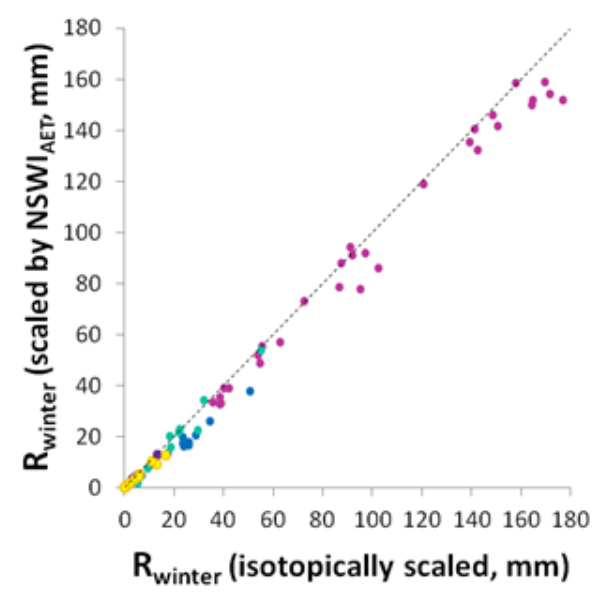

b)

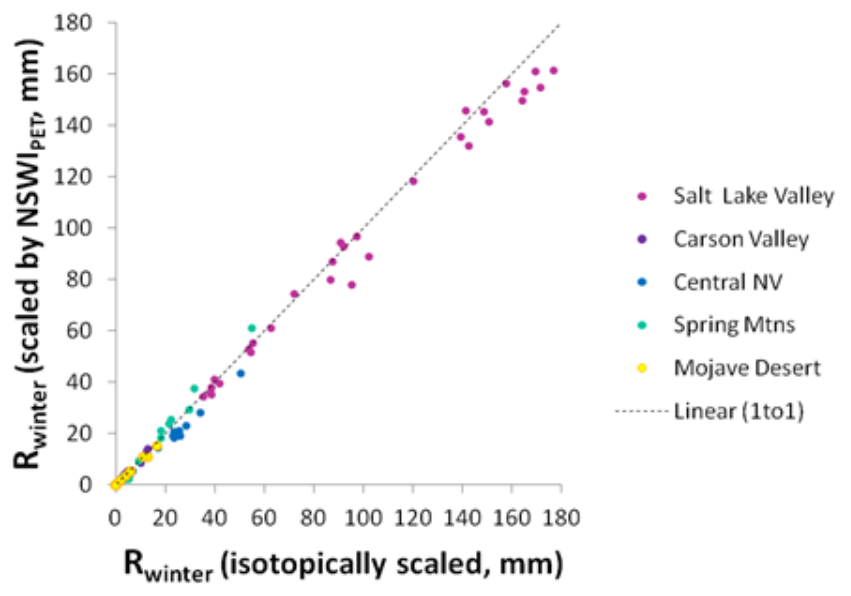

Figure 7. Correlation between isotopically-scaled winter recharge length and NSWI-scaled recharge length using (a) AET; and (b) PET for northern basins. Empirical annual total recharge determined using the MaxeyEakin method. 
a)

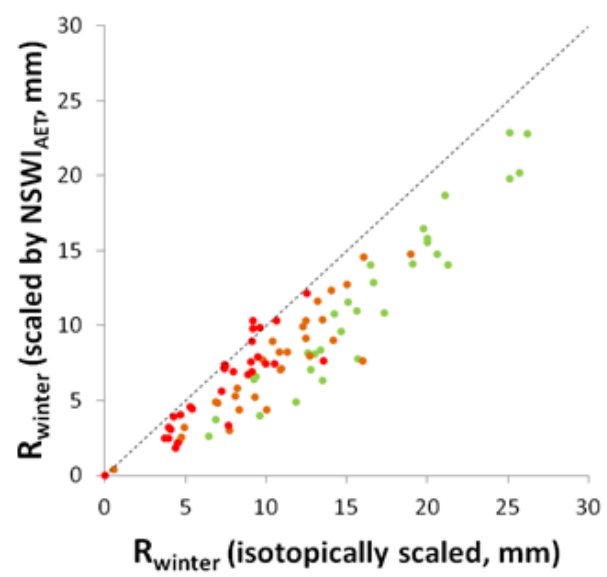

b)

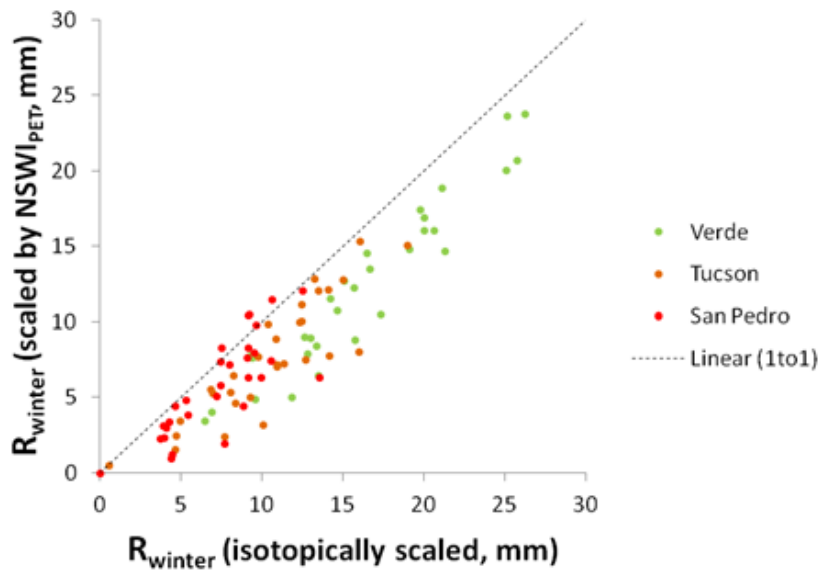

Figure 8. Correlation between isotopically-scaled winter recharge length and NSWI-scaled recharge length using (a) AET; and (b) PET for Arizona basins. Empirical annual total recharge determined using the Anderson equation.

a)

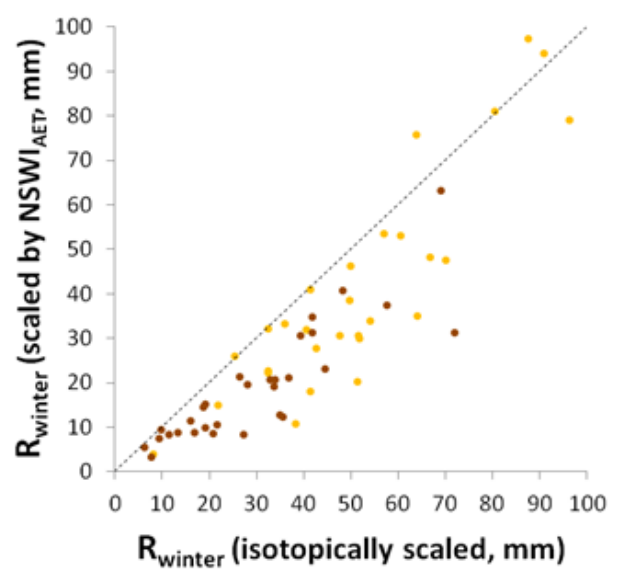

b)

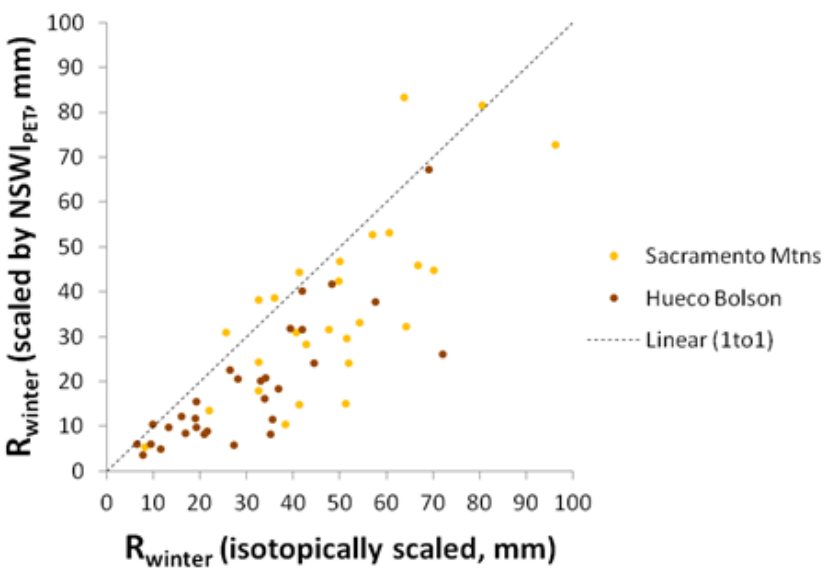

Figure 9. Correlation between isotopically-scaled winter recharge length and NSWI-scaled recharge length using (a) AET; and (b) PET for Río Grande Valley basins. Empirical annual total recharge determined using the Waltemeyer method. 


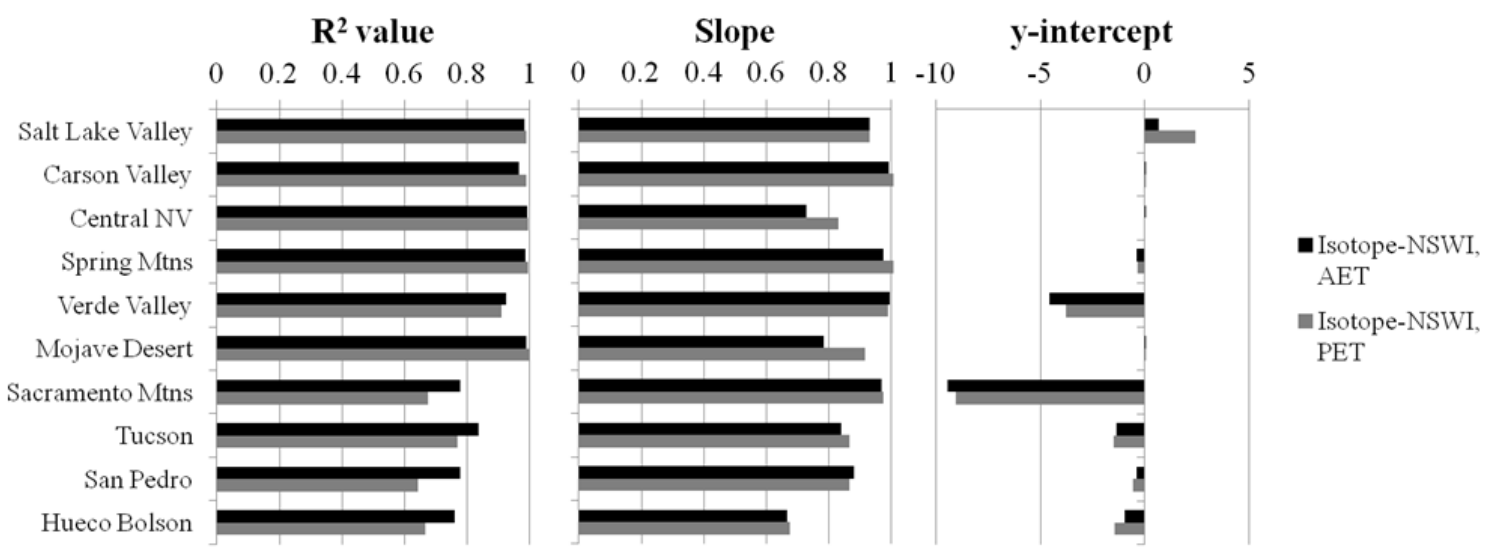

Figure 10. $\mathbf{R}^{2}$ values, slope, and $y$-intercept for the best fit line correlation between isotopically-scaled and NSWI-scaled winter recharge lengths, using both AET and PET.

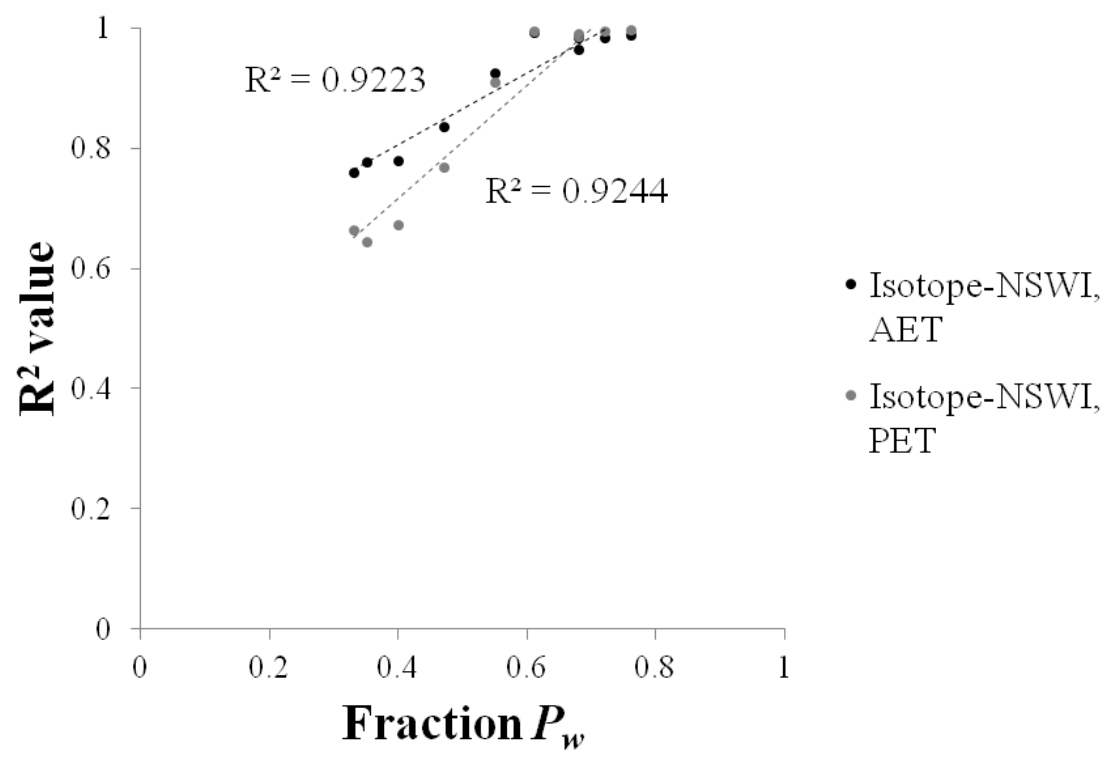

Figure 11. $\mathbf{R}^{2}$ values for the correlation between isotopically-scaled and NSWI-scaled winter recharge lengths, using both AET and PET, as a function of a) longitude; b) isotopically-derived winter recharge fraction. 


\title{
APPENDIX C: Seasonal Hydrologic Controls on Riparian Corridor Productivity in the Arid and Semi-arid Western United States
}

\author{
Kirstin L. Neff', Willem van Leeuwen ${ }^{2,3}$, Thomas Meixner ${ }^{1}$, Kyle Hartfield ${ }^{2}$ \\ ${ }^{1}$ University of Arizona, Department of Hydrology and Water Resources, Tucson, AZ, USA \\ ${ }^{2}$ University of Arizona, School of Natural Resources and the Environment, Tucson, AZ, USA \\ ${ }^{3}$ University of Arizona, School of Geography and Development, Tucson, AZ, USA
}

\begin{abstract}
River baseflows and riparian groundwater that support critical ecosystem services and biodiversity in arid and semi-arid riparian corridors are sustained by groundwater recharge occurring over variable time scales and controlled by local climate, topography, and geology. This study applies the techniques of vegetation detection using remote sensing to examine the interaction between hydrologic, climatic, and geographical variables and seasonal changes in riparian vegetation productivity. Land cover classifications are conducted using classification and regression tree (CART) models for four basins in the Basin and Range and coupled with spatial analysis to isolate riparian corridors. Riparian and non-riparian Normalized difference vegetation index (NDVI) values are compared between three seasons (winter, early summer, and later summer) to examine and measure the response of riparian vegetation to seasonal climatic and hydrological processes. The seasonality of recharge was not found to have a significant impact on the productivity of riparian corridors, except at low elevation during the winter season. In general, the NDVI of riparian vegetation depended more on the seasonality of precipitation (winter at high elevation; early summer at low and high elevation; late summer at low elevation) or the spread of temperatures experienced annually (late summer at high elevation).
\end{abstract}




\section{INTRODUCTION}

Riparian corridors in the arid and semi-arid Basin and Range Geological Province of the western United States support high biodiversity in otherwise biologically lowproductivity regions by providing critical habitat for migrating birds, endemic aquatic species, and deciduous broadleaf forests (Leenhouts et al., 2006; Stromberg and Tellman, 2009). Diversions of surface water and pumping of groundwater, as well as projected climate change, threaten the availability of water to these environmental users (Seager et al., 2007; Stromberg et al., 2007; Nguyen et al., 2014). River baseflows and riparian groundwater are sustained by groundwater recharge occurring over variable time scales and controlled by local climate, topography, and geology (Wilson and Guan, 2004; Leenhouts et al., 2006). In considering how climate change will impact interannual riparian water availability, it is important to first understand the intra-annual hydrologic processes contributing to seasonal variations in water availability and riparian vegetation growth cycles. How do seasonal variations in precipitation, recharge, and temperature interact in Basin and Range watersheds to influence seasonal cycles of riparian vegetation NDVI?

\section{The role of riparian corridors in regional biodiversity}

Riparian tree species native to western arid and semi-arid regions provide many ecological services to an otherwise biomass-poor system. Riparian trees such as cottonwood, willow, sycamore, and netleaf hackberry provide habitat preferred by migrating bird species (Powell and Steidl, 2002; Stromberg and Tellman, 2009). The quality and distribution of habitat for migrating birds is dependent upon the distribution of deciduous riparian tree species, which in turn depends upon depth to groundwater and surface flow regime (Merritt and Bateman, 2012). Deciduous tree species sustain riparian 
food webs by making groundwater available to insects and animals via greenfall (Sabo et al., 2008). Riparian mesquite forests support higher soil moisture and organic matter in the root zone, which promotes microbial activity (Schade and Hobbie, 2005; Sponseller and Fisher, 2006). Beyond the biodiversity benefits, riparian corridors provide green space that increases nearby property values (Bark et al., 2011).

Riparian tree species are physiologically sensitive to and threatened by even slight decreases in water availability (Letts et al., 2008). At the same time, riparian trees typically found in western arid and semi-arid regions are some of the largest environmental water users, constituting a feedback mechanism in the basin water budget (Cleverly et al., 2006). As riparian forests transpire surface and soil water, they impact recharge and groundwater storage.

Invasive species such as the Tamarix ramosissima (salt-cedar) are well-adapted to water-limited environments because of their deep roots (Cleverly et al., 2006; Merritt and Poff, 2010). As baseflow and riparian groundwater decrease, native cottonwoods and willows are quick to respond physiologically to the lack of soil water (Hutline et al., 2010). Declines in riparian water availability due to climate change and/or anthropogenic alteration of streamflow allow Tamarix to outcompete native cottonwood and willow species, causing a shift in the composition of riparian corridors over time (Stromberg et al., 2007).

\section{Groundwater sustains arid and semi-arid riparian ecosystems}

Seasonal variations in transpiration in water-limited semi-arid ecosystems have been shown to be coupled to the timing of precipitation in different ways than energylimited temperate ecosystems, where green-up and respirations are primarily related to temperature changes (Yepez et al., 2007). However, many studies have shown the 
importance of riparian groundwater in sustaining riparian vegetation. The availability of riparian groundwater is the product of several factors, one being rates of basin recharge that bring new water to riparian aquifers over varying time scales. Could this hydraulic connection between recharge and riparian water availability result in a measureable seasonal relationship between riparian vegetation and the timing of recharge?

\section{METHODS}

Past studies have mapped riparian corridors in order to examine impacts on riparian vegetation NDVI from streamflow regimes (Auble et al., 1994), water abstraction for human use (Nguyen et al., 2014), and several variables combined, including maximum temperature, antecedent rainfall, the lengths of inter-flood dry periods, and groundwater levels (Fu and Burgher, 2015). This study aims to examine the relationships between intra-annual seasonal hydrological cycles and vegetation cycles by mapping riparian and non-riparian NDVI across a range of elevations in four basins spread across the domain of the Basin and Range Province (Figure 1). Riparian and nonriparian NDVI is compared between three seasons (winter, early summer, and late summer) and related to hydrologic and climatic variables to identify possible drivers of seasonal NDVI change in the region, including the range of mean monthly temperatures annually, basin elevation at the outlet, and the fraction winter precipitation and recharge.

\section{Multispectral imagery}

In order to identify a representative year for which to collect high-resolution multispectral imagery, NDVI values from MODIS images of subsetted 4-pixel clusters encompassing the centroid of each basin were examined for the period 2000-2014

(ORNL, 2015) (Figure 2). 2008 was chosen as a representative year in which none of the basins experienced extremely high or low NDVI values. Atmospherically-corrected, 30 
m-resolution multispectral imagery from Landsat 5 Thematic Mapper (TM) were ordered using USGS Earth Explorer for select days in the months of March, June, and September (USGS, 2015a). These months were chosen for their timing at the end of the three precipitation seasons present in the Basin and Range Province: winter (Oct-Mar), dry early summer (Apr-Jun), and wet late summer monsoon (Jul-Sep).

For months in which there was more than one day of imagery, one day was chosen for its temporal proximity to data available in other basins. If the chosen image included prohibitive cloud cover, a different image from that month with less cloud cover was chosen. There was one case where an image from the month of February was used to represent winter vegetation conditions because all of the available March images had prohibitive cloud cover (Table 1).

Some basins were located such or of such size that it was necessary to collect multiple images from different paths and/or rows to completely cover the basin extent (Table 1). In these cases, adjacent images were collected for the day closest to the day of the primary image, and the multiple images were mosaick-ed together. Where images overlapped, the primary image or the image whose date was closest to the primary image was overlaid on top of the other image, giving precedence to that image.

\section{Normalized difference vegetation index (NDVI)}

Once the composite imagery had been created from the individual Landsat 5 TM imagery, rasters of NDVI for each scene were created using the ERDAS Imagine 13 imagery processing software. NDVI is a measure of vegetation greenness determined using the red visible light and near infrared spectrums, covered here by Landsat 5 TM bands $3(0.63-0.69 \mu \mathrm{m})$ and $4(0.76-0.9 \mu \mathrm{m})$ respectively (USGS, 2015b). NDVI has been used extensively as a corollary for photosynthetically active vegetation in semi-arid 
riparian corridors (Jones et al., 2008; Letts et al., 2008; Dennison et al., 2009; Nguyen et al., Fu and Bergher, 2015). NDVI is calculated from reflectance ( $\rho$ ) in the red visible light and near infrared spectrums (Deering and Haas, 1980):

$$
N D V I=\frac{\rho_{\text {NIR }}-\rho_{\text {red }}}{\rho_{\text {NIR }}+\rho_{\text {red }}}
$$

\section{Basin delineation}

Basin boundaries were assembled from several different sources, including state and national geospatial data depositories (Table 2). Stacked multispectral imagery and NDVI rasters were clipped to these boundaries prior to being used as the basis for land cover classifications.

\section{Land cover classifications}

In order to identify pixels of riparian vegetation for analysis, land cover classifications were conducted for each basin using classification and regression tree (CART) models trained with data points based on high-spatial resolution, temporallycoincident satellite imagery in Google Earth and red-green-blue (RGB) false color composite images created from Landsat 5 TM bands 4, 3, and 2. The CART models for each basin were created from sets of six images, which included the full 6-layer stack of Landsat 5 TM data as well as NDVI for all three seasons, and a set of training data with at least 60 points for each land cover class. The CART method was chosen for its proven success in accurately classifying semi-arid riparian vegetation (Villareal et al., 2012).

Land cover classes were modeled after those used by Villareal et al. (2012) (and based on Anderson (1976)), which also sought to separate riparian vegetation from other vegetation classes in a semi-arid basin. One land cover class was added for the purposes of these classifications (Table 3). That class is grass, to reflect maintained sod on golf 
courses and athletic fields. For each basin, land cover classes were used selectively according to their presence or absence in that basin.

The National Land Cover Database (NLCD) toolbox for ERDAS Imagine 13 and See 5 were used to conduct the CART classifications. In See5, the classifier was constructed using the winnow attributes, boost, and global pruning options. Accuracy of land cover classifications were calculated using a confusion matrix, which is the ratio of correctly classified validation points to the total number of training points of that land cover type (Congalton, 1991). For every basin, there were at least 30 training points and 30 validation points.

\section{Seasonal and elevational patterns in NDVI in and out of the riparian corridor}

In order to conduct the seasonal analyses on riparian and non-riparian vegetation, riparian pixels were selected from the CART land cover classification for each basin to create a riparian raster mask. To isolate pixels covering riparian vegetation and exclude misclassified pixels far from riparian areas, the riparian vegetation raster masks were clipped to buffer polygons extending 200 meters in either direction from the higher order stream segments contained within each basin's boundaries. Stream networks were assembled from the National Hydrography Dataset and Mexico's National Institute of Statistics and Geography (Table 2).

To create the non-riparian raster mask for each basin, all pixels falling within the $200 \mathrm{~m}$ stream buffer zone were removed from the domain. Thus, pixels outside the riparian corridor and misclassified as riparian by the land cover classification were included in the non-riparian mask. The riparian and non-riparian masks for each basin were used to extract NDVI values for riparian and non-riparian pixels from the three seasonal NDVI rasters for each basin. 
Riparian and non-riparian seasonal NDVI rasters for each basin were divided further into separate swaths of 200 m-elevation ranges. The elevation swaths were created by selecting pixels falling within the designated elevation ranges to create elevation range masks. The elevation ranges differed for each basin due to their different locations and topographies. Riparian and non-riparian NDVI rasters were created for each elevation range by selecting pixels using the elevation range masks. Mean riparian and non-riparian NDVI and standard deviation for each season for each elevation range was determined from these rasters. The elevation at the basin outlet was also determined from the DEMs to evaluate the impact of basin elevation on riparian NDVI.

\section{Hydrological and climatic data}

Monthly climatic data for 2008 were collected for each basin for the purpose of comparison to seasonal NDVI values (NOAA, 2015). Data for 2008 specifically was not available in the Río San Miguel, so mean monthly values over a period 1974-2007 were used (CICESE, 2015). The difference between maximum and minimum mean monthly temperature, as well as fraction winter precipitation, were calculated from these data. Data on the seasonality of recharge in these basins, represented as winter recharge fraction, were taken from stable isotope-based estimations (Neff et al., in-prep).

\section{RESULTS AND DISCUSSION}

\section{Land cover classification of riparian corridors}

Land cover classification of the study basins using CART models were moderately successful, with overall accuracies ranging from $72-80 \%$, and riparian zone accuracies ranging from 62-78\% (Table 4). Corridors of riparian vegetation are visible in all four basins (Figure 3). The greatest confusion in classification occurred between nonriparian and riparian classes of similar vegetation cover. For example, upland forest was 
frequently misclassified as riparian forest in Little Fish Lake Valley. To address this issue, only pixels within $200 \mathrm{~m}$ of the stream course were used to conduct the analysis of riparian NDVI. A buffer within $200 \mathrm{~m}$ of a stream course can be reasonably assumed to include vegetation with access to riparian water along the main stream course of a river and has been used in a similar study (Nguyen et al., 2014). Using this buffer diminishes the impact of these misclassifications on the analysis. Misclassifications among nonriparian classes (such as the misclassification of barren land as developed land in the Upper Verde) do not likely impact the results since all pixels outside of the riparian buffer were included in the non-riparian analysis (Figure 3).

\section{Seasonal and elevational patterns of riparian and non-riparian NDVI}

Riparian and non-riparian NDVI from 200 m elevation swaths were compared for each basin. To simplify this analysis, only the lowest elevations and highest elevations for each basin are examined here (Figure 4). This is justified by the finding that mean riparian and non-riparian NDVI values in the intervening elevations plotted along a continuum of change between the low and high elevation sites. The low and high elevations sites experienced the greatest and least difference between mean riparian and non-riparian NDVI, respectively. Although there was a clear elevational pattern in the difference between mean riparian and non-riparian NDVI for all basins, only in several cases was there statistical significance between mean riparian and non-riparian NDVI: in the late summer season at low elevation in the Verde Basin, and in the early and late summer seasons at low elevation in the Sacramento Mountains (Figure 4). This finding suggests that for the most part, there is not a significant difference between riparian and non-riparian NDVI in these basins, and particularly not at the highest elevations. Where there was a significant difference, mean riparian NDVI was greater than non-riparian 
NDVI, which is to be expected due to assumed greater water availability to vegetation in riparian zones.

In general, non-riparian NDVI was greater at high elevation (Figure 4). The lowest NDVI values recorded occurred during the winter at high elevation in the Little Fish Lake Valley, indicating the impact of winter snow pack at this higher latitude site. Intra-annual seasonal differences in NDVI were more pronounced at low elevation and for sites at high latitude and impacted by snow cover (Little Fish Lake Valley) and low latitude (San Miguel Basin). All basins except the Little Fish Lake Valley experienced their greatest mean riparian NDVI during the late summer season (Figures 4 and 5). The Little Fish Lake Valley experienced its greatest mean riparian NDVI during the early summer season, with a slight decline to the late summer season. This result reflects the Little Fish Lake Valley's northern-most location, out of the zone of influence of the North American Monsoon.

All basins except the San Miguel Basin experienced their lowest mean riparian NDVI at low elevation during the winter season, when deciduous vegetation is dormant or just coming out of dormancy (Figure 4 and 5). For the San Miguel Basin, the lowest mean riparian NDVI at low elevation occurred during the dry summer season, just before the onset of the monsoon (though the difference between mean riparian NDVI in winter and early summer in the San Miguel Basin is not significant, being within each other's margin of error). In the Sacramento Mountains and San Miguel Basin, riparian NDVI at high elevation was actually lower than non-riparian NDVI during the winter. This difference might be explained by the contrast between dormant deciduous riparian trees and evergreen non-riparian trees 
Examining subsets of the riparian and non-riparian data up close, the above observed differences between riparian and non-riparian NDVI are visible (Figures 6 and 7). At both high and low elevation, the land cover classification and $200 \mathrm{~m}$ stream buffer successfully identified riparian vegetation. High NDVI-agricultural areas at low elevation were excluded from the riparian classes, and the stream buffer mostly excluded those agricultural areas from being included in the non-riparian area, preventing those nearstream agricultural areas from unduly influencing non-riparian NDVI values. At both high and low elevation in the Sacramento Mountains, riparian NDVI increases from winter to early summer and again to late summer (Figures 6 and 7). However, when the non-riparian pixels are examined, two different trends emerge. At low elevation, NDVI generally decreases away from the riparian zone (Figure 6e). At high elevation, NDVI appears to be independent of distance from the stream course, and exhibits an elevational gradient parallel to the stream course (Figure 7e).

\section{Hydrologic, climatic, and geographic impacts on riparian NDVI through the seasons}

There were differences in the correlation of riparian NDVI with hydrologic, climatic, and geographic variables between high and low elevation for all seasons (Figures 8-10). In winter, riparian NDVI at low elevation was correlated most strongly with the basin's fraction winter recharge $\left(\mathrm{R}^{2}=0.949\right)$, and at high elevation was correlated most strongly with fraction winter precipitation $\left(R^{2}=0.872\right)$. At low elevation, riparian NDVI was negatively correlated with winter recharge fraction, meaning that basins that experienced a greater proportion of summer recharge had greater riparian NDVI in the winter season. One possible explanation for this could be a delayed impact of summer recharge on water availability in the riparian zone. The correlation at high elevation was also negative, meaning that basins that receive a greater proportion of 
summer precipitation have greater winter riparian NDVI. The driver of these correlations is not clear, but may have to do with basins that receive more summer precipitation and recharge being at lower latitudes, and thus experiencing less snow pack and warmer winter temperatures. NDVI has been shown to be positively correlated with temperature globally (Ichii et al., 2002) and in semi-arid regions specifically (Fu and Burgher, 2015).

In early (dry) summer, riparian NDVI at both low and high elevation were negatively and most correlated with fraction winter precipitation $\left(R^{2}=0.306\right.$ and 0.658 , respectively). This correlation seems to be straightforward: basins that received a greater proportion of summer precipitation had greater early summer NDVI. The low correlation of this season with any of the variables examined here prompts further inquiry into other possible drivers.

In the late (wet) summer, riparian NDVI at low elevation was most correlated (negatively) with fraction winter precipitation $\left(\mathrm{R}^{2}=0.954\right)$. This correlation again seems straightforward, as more summer precipitation leads to greater summer riparian NDVI. The fact that this correlation was higher in the late summer than in the early summer speaks to the lag of green-up after the arrival of summer rains. Méndez-Barroso et al. (2009) found that in the San Miguel Basin, green-up was better correlated with accumulated precipitation when more preceding months were included in the total, suggesting that water availability is integrated through physical processes over time, and does not respond immediately to precipitation inputs. At high elevation, late summer riparian NDVI was most correlated (negatively) with the range of monthly mean temperatures in the basin $\left(R^{2}=0.7753\right)$. Basins with a smaller annual temperature range (closer to a tropical climate) experienced greater late summer NDVI at high elevation. 
Absolute temperature as be shown to be positively correlated with NDVI in semi-arid regions (Ichii et al., 2002), but temperature range appears to be negatively correlated with NDVI.

\section{CONCLUSIONS}

The seasonality of recharge does not appear to have a significant impact on the NDVI of riparian corridors at any elevation. The NDVI of riparian vegetation depended more on the seasonality of precipitation or the spread of temperatures experienced annually. However, winter low elevation riparian NDVI did have a strong correlation with recharge seasonality, suggesting that under some circumstances, NDVI in the riparian corridor is driven by recharge timing.

\section{Future directions}

This study would be improved by the addition of more basins to the analysis, making the correlations between riparian NDVI and hydrologic, climatic, and geographical variables clearer. With such a small set of data points, the addition of new data points may have a great impact on these correlations. Ideally, 30 basins would be compared. However, Neff et al. (in-prep) examines only 11 basins. Expanding to 11 basins would nearly double the sample size, however, likely improving the statistical significance of any correlations. Furthermore, the manner of analysis of these correlations could be improved by adopting different methods for quantifying correlation, or the explanatory power of the hydrologic, climatic, and geographical variables. Potential methodologies used in similar studies include regression tree analysis (Fu and Burgher, 2015) and multiple linear regression (Nguyen et al., 2014). 


\section{ACKNOWLEDGMENTS}

This paper was developed under STAR Fellowship Assistance Agreement no. FP91749101-0 awarded by the U.S. Environmental Protection Agency (EPA). It has not been formally reviewed by EPA. The views expressed in this paper are solely those of Kirstin L. Neff, and EPA does not endorse any products or commercial services mentioned in this paper. 


\section{REFERENCES}

Anderson JF, Hardy EE, Roach JT, Witmer RE. 1976. A Land Use and Land Cover Classification System for Use with Remote Sensor Data. Washington, DC: U.S. Geological Survey.

Auble GT, Friedman JM, Scott ML. 1994. Relating riparian vegetation to present and future streamflows. Ecological Applications 4(3): 544-554.

Baillie MN, Hogan JF, Ekwurzel B, Wahi AK, Eastoe CJ. 2007. Quantifying water sources to a semi-arid riparian ecosystem, San Pedro River, Arizona. Journal of Geophysical Research 112, G03S02, doi:10.1029/2006JG000263.

Bark RH, Osgood DE, Colby BG, Halper EB. 2011. How do homebuyers value different types of green space? Journal of Agricultural and Resource Economics 36(2): 395-415.

Blasch KW, Bryson JR. 2007. Distinguishing sources of ground water recharge by using $\delta \mathrm{D}$ and $\delta^{18} \mathrm{O}$. Ground Water 45(3): 293-308. doi: 10.1111/j.1745-6584.2006.00289.x.

Castro CL, Chang H, Dominguez F, Carillo C, Schemm J, Juang HH. 2012. Can a regional climate model improve the ability to forecast the North American Monsoon? Journal of Climate 25: 8212-8237.

CICESE. 2015. Base de datos climáticos del noroeste de México. Accessed 3/20/2015 at http://peac-bc.cicese.mx/datosclim/dcbc.php.

Clark ID, Fritz P. 1997. Environmental Isotopes in Hydrogeology. CRC Press: New York. 328pp.

Cleverly JR, Dahm CN, Thibault JR, McDonnell DE, Coonrod JEA. 2006. Riparian ecohydrology: regulation of water flux from the ground to the atmosphere in the Middle Río Grande, New Mexico. Hydrological Processes 20: 3207-3225. doi:10.1002/hyp.6328.

Coes A. Personal communication, March 10, 2015.

Congalton RG. 1991. A review of assessing the accuracy of classifications of remotely sensed data. Remote Sensing of Environment 37(1): 35-46. doi:10.1016/00344257(91)90048-B.

Deering DW, Haas RH. 1980. Using Landsat digital data for estimating green biomass. NASA Technical Memorandum \#80727. 21 pp.

Dennison PE, Nagler PL, Hultine KR, Glenn EP, Ehleringer JR. 2009. Remote monitoring of tamarisk defoliation and evapotranspiration following saltcedar leaf beetle attack. Remote Sensing of Environment 113: 1462-1472. 
Dominguez F, Rivera E, Lettenmaier DP, Castro CL. 2012. Changes in winter precipitation extremes for the western United States under a warmer climate as simulated by regional climate models, Geophysical Research Letters. doi: 10.1029/2011GL050762.

Fu B, Burgher I. 2015. Riparian NDVI dynamics and its relationship with climate, surface water and groundwater. Journal of Arid Environments 113: 59-68.

doi:10.1016/j.jaridenv.2014.09.010.

Hutline KR, Bush SE, Ehleringer JR. 2010. Ecophysiology of riparian cottonwood and willow before, during, and after two years of soil water removal. Ecological Applications 20(2): 347-361.

Ichii K, Kawabata A, Yamaguchi Y. 2002. Global correlation analysis for NDVI and climatic variables and NDVI trends: 1982-1990. International Journal of Remote Sensing 23: 3873-3878.

Instituto Nacional de Estadística y Geografía. 2015. Red Hidrografica escala 1:50 000 edicion 2.0 - descarga. Accessed March 20, 2015 at http://www.inegi.org.mx/geo/contenidos/recnat/hidrologia/Descarga.aspx.

Jones KB, Edmonds CE, Slonecker ET, Wickham JD, Neale AC, Wade TG, Riitters KH, Kepner WG. 2008. Detecting changes in riparian habitat conditions based on patterns of greenness change: A case study from the Upper San Pedro River Basin, USA. Ecological Indicators 8: 89-99. doi:10.1016/j.ecolin.2007.01.001.

Leenhouts JM, Stromberg JC, Scott RL. 2006. Hydrologic requirements of and consumptive ground-water use by riparian vegetation along the San Pedro River, Arizona. U. S. Geological Survey, Scientific Investigations Report 2005-5163.

Letts MG, Phelan CA, Johnson DRE, Rood SB. 2008. Seasonal photosynthetic gas exchange and leaf reflectance characteristics of male and female cottonwoods in a riparian woodland. Tree Physiology 28: 1037-1048.

Méndez-Barroso LA, Vivoni ER, Watts CJ, Rodríguez JC. 2009. Seasonal and interannual relations between precipitation, surface soil moisture and vegetation dynamics in the North American monsoon region. Journal of Hydrology 377: 59-70.

Merritt DM, Bateman HL. 2012. Linking stream flow and groundwater to avian habitat in a desert riparian system. Ecological Applications 22(7): 1973-1988.

Merritt DM, Poff NL. 2010. Shifting dominance of riparian Populus and Tamarix along gradients of flow alteration in western North American rivers. Ecological Applications 20(1): 135-152.

National Oceanic and Atmospheric Administration. 2015. Climate data online. Accessed 3/20/2015 at http://www.ncdc.noaa.gov/cdo-web/. 
Neff KL, Meixner T, De La Cruz L, Ajami H. Seasonality of Groundwater Recharge in the Basin and Range Province, Western North America. In-prep.

Nevada Division of Water Resources. 2015. GIS Data. Accessed February 18, 2015 at http://water.nv.gov/mapping/gis/.

New Mexico Office of the State Engineer. 2015. Geospatial data. Accessed March 9, 2015 at http://www.ose.state.nm.us/GIS/geospatial_data.php.

Nguyen U, Glenn EP, Nagler PL, Scott RL. 2014. Long-term decrease in satellite vegetation indices in response to environmental variables in an iconic desert riparian ecosystem: the Upper San Pedro, Arizona, United States. Ecohydrology.

doi:10.1002/eco.1529.

Oak Ridge National Laboratory. 2015. MODIS global subsets: data subsetting and visualization. Accessed February 18, 2015 at http://daac.ornl.gov/cgi-

bin/MODIS/GLBVIZ_1_Glb/modis_subset_order_global_col5.pl.

Powell BF, Steidl RJ. 2002. Habitat selection by riparian songbirds breeding in southern Arizona. Journal of Wildlife Management 66(4): 1096-1103.

Rose TP, Kersting AB, Harris LJ, Hudson GB, Smith DK, Williams RW, Loewen DR, Nelson EJ, Allen PG, Ryerson FJ, Pawloski GA, Laue CA, Moran JE. 2003. Stable Isotope Investigation of Precipitation and Recharge Processes in Central Nevada. In Hydrologic Resources Management Program and Undeground Test Area Project, 2001 2002 Progress Report. Pgs. 113-134.

Sabo JL, McCluney KE, Marusenko Y, Keller A, Soykan CU. 2008. Greenfall links groundwater to aboveground food webs in desert river floodplains. Ecological Monographs 78(4): 615-631.

Schade JD, Hobbie SE. 2005. Spatial and temporal variation in islands of fertility in the Sonoran Desert. Biogeochemistry 73: 541-553.

Seager R, Ting M, Held IEA. 2007. Model projections of an imminent transition to a more arid climate in southwestern North America. Science 5828: 1181-1184.

Simpson ES, Thorud DB, Friedman I. 1972. Distinguishing seasonal recharge to groundwater by deuterium analysis in southern Arizona. In World Water Balance, Proceedings of the 1970 Reading Symposium, International Association of Scientific Hydrology. UNESCO-WMO; 623-633.

Simpson SC, Meixner T, Hogan JF. 2013. The role of flood size and duration on streamflow and riparian groundwater composition in a semi-arid basin. Journal of Hydrology 488: 126-135.

Sponseller RA, Fisher SG. 2006. Drainage size, stream intermittency, and ecosystem function in a Sonoran Desert landscape. Ecosystems 9(3): 344-356. 
Stromberg JC, Lite SJ, Marler R, Paradzick C, Shafroth PB, Shorrock D, White JM, White MS. 2007. Altered stream-flow regimes and invasive plant species: the Tamarix case. Global Ecology and Biogeography 16: 381-393.

Stromberg, JC, Tellman B. 2009. Introduction, in Ecology and Conservation of the San Pedro River. Stromberg JC, Tellman B eds. Tucson, AZ: University of Arizona Press, 112.

U.S. Geological Survey. 2015a. Earth Explorer. Accessed February 24, 2015 at http://earthexplorer.usgs.gov/.

U.S. Geological Survey. 2015b. Frequently asked questions about the Landsat missions. Accessed March 20, 2014 at http://landsat.usgs.gov/band_designations_landsat_satellites.php.

U.S. Geological Survey. 2015c. National Hydrography Dataset. Accessed March 20, 2015 at http://nhd.usgs.gov/.

Villareal ML, Van Leeuwen WJD, Romo-Leon JR. 2012. Mapping and monitoring riparian vegetation distribution, structure and composition with regression tree models and post-classification change metrics. International Journal of Remote Sensing 33(13): 4266-4290. doi:10.1080/01431161.2011.644594.

Vivoni ER, Bowman RS, Wyckoff RL, Jakubowski RT, Richards KE. 2006. Analysis of a monsoon flood event in an ephemeral tributary and its downstream hydrologic effects. Water Resources Research 42(3): W03404, doi:10.1029/2005WR004036.

Wilson JL, Guan H. 2004. Mountain-block hydrology and mountain-front recharge. In Groundwater Recharge in a Desert Environment: the Southwestern United States, Hogan JF, Phillips FM, Scanlon BR (eds.), American Geophysical Union: Washington D.C.: 113-137.

Yepez EA, Scott RL, Cable WL, Williams DG. 2007. Intraseasonal variation in water and carbon dioxide flux components in a semi-arid riparian woodland. Ecosystems 10: 11001115. doi:10.1007/s10021-007-9079-y. 


\section{TABLES}

Table 1. Landsat 5 TM multispectral imagery used

\begin{tabular}{|c|c|c|c|}
\hline Basin & Image Path & Image Row & Image Dates \\
\hline Little Fish Lake Valley (NV) & 40 & 33 & $\begin{array}{l}\text { March 21, } 2008 \\
\text { June 9, } 2008 \\
\text { September 13, } 2008\end{array}$ \\
\hline \multirow[t]{2}{*}{ Upper Verde River Basin (AZ) } & 37 & 36 & $\begin{array}{l}\text { February } 29,2008 \\
\text { June } 20,2008 \\
\text { September } 24,2008\end{array}$ \\
\hline & 38 & 36 & $\begin{array}{l}\text { March 7, } 2008 \\
\text { June 27, } 2008 \\
\text { September 15, } 2008 \\
\end{array}$ \\
\hline \multirow[t]{2}{*}{ Rio San Miguel Basin (MX) } & 35 & 39 & $\begin{array}{l}\text { March 18, } 2008 \\
\text { June 6, } 2008 \\
\text { September 10, } 2008 \\
\end{array}$ \\
\hline & 35 & 40 & $\begin{array}{l}\text { March 18, } 2008 \\
\text { June 6, } 2008 \\
\text { September } 10,2008\end{array}$ \\
\hline \multirow[t]{2}{*}{ Sacramento Mountains (NM) } & 32 & 37 & $\begin{array}{l}\text { March 13, } 2008 \\
\text { June 1, 2008 } \\
\text { September 5, } 2008 \\
\end{array}$ \\
\hline & 33 & 37 & $\begin{array}{l}\text { March 20, } 2008 \\
\text { June 8, } 2008 \\
\text { September 28, } 2008\end{array}$ \\
\hline
\end{tabular}

Table 2. Data sources for stream networks and basin boundaries

\begin{tabular}{|l|l|l|}
\hline & $\begin{array}{l}\text { Stream Network } \\
\text { Source }\end{array}$ & Boundary Source \\
\hline Little Fish Lake Valley (NV) & USGS, 2015c & NDWR, 2015 \\
\hline Upper Verde River Basin (AZ) & USGS, 2015c & Coes, 2015 \\
\hline Rio San Miguel Basin (MX) & INEGI, 2015 & INEGI, 2015 \\
\hline Sacramento Mountains (NM) & USGS, 2015c & $\begin{array}{l}\text { NMOSE, 2015 (Peñasco, Hondo, } \\
\text { and part of Roswell basins) }\end{array}$ \\
\hline
\end{tabular}


Table 3. Land cover classification scheme (adapted from Villareal et al., 2012)

\begin{tabular}{|c|c|}
\hline Land cover class & Description \\
\hline Agriculture & Row crops \\
\hline Barren & Rock and bare soil \\
\hline Upland Forest & Tree cover $>60 \%$, non-riparian \\
\hline Developed & $\begin{array}{l}\text { Areas of disturbance for commercial, industrial, and residential } \\
\text { structures }\end{array}$ \\
\hline Herbaceous & $\begin{array}{l}\text { Herbaceous dominated, non-riparian. Tree cover }<10 \% \text {, shrub cover } \\
<10 \%\end{array}$ \\
\hline Woodland & Tree cover dominant type, but $<60 \%$ total cover \\
\hline Riparian forest & Tree cover $>60 \%$, dominated by cottonwood and willow species. \\
\hline Riparian woodland & Tree cover dominant, but $<60 \%$ \\
\hline Shrub savanna & Herbaceous dominated, shrub cover present but $<10 \%$ \\
\hline Shrubland & Shrub cover $>50 \%$ \\
\hline Tree savanna & Herbaceous dominated, tree cover present but $<10 \%$ \\
\hline Water & Water \\
\hline Grass & Maintained sod for golf courses and athletic fields \\
\hline
\end{tabular}

Table 4. Accuracy assessments of land cover classifications

\begin{tabular}{|l|c|c|}
\hline Basin & Overall accuracy & Riparian Accuracy \\
\hline Little Fish Lake Valley (NV) & $80 \%$ & $78 \%$ \\
\hline Upper Verde River Basin (AZ) & $73 \%$ & $73 \%$ \\
\hline Rio San Miguel Basin (MX) & $68 \%$ & $62 \%$ \\
\hline Sacramento Mountains (NM) & $73 \%$ & $64 \%$ \\
\hline
\end{tabular}




\section{FIGURES}

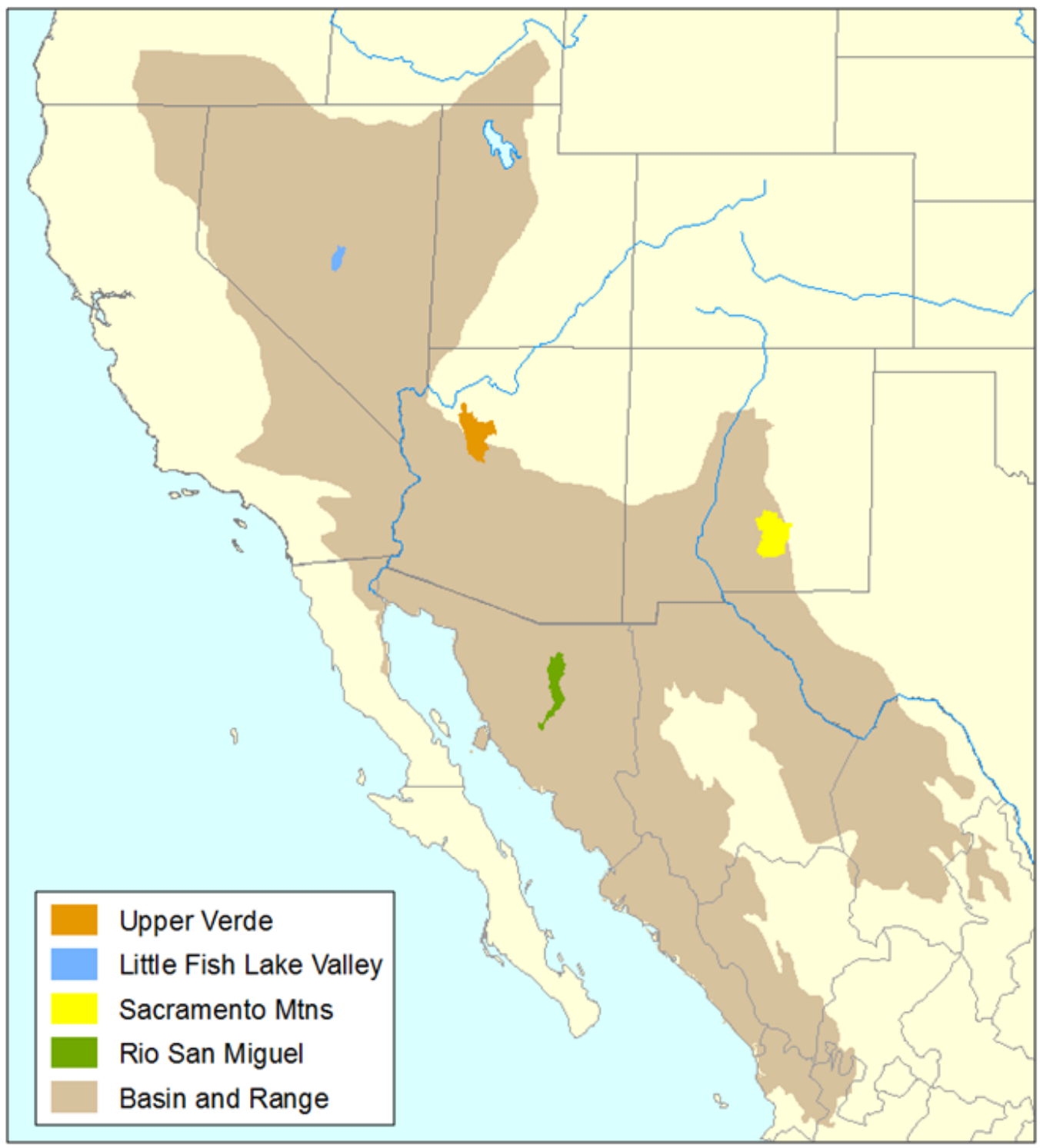

Figure 1. Location of study basins within the Basin and Range Geological Province. 


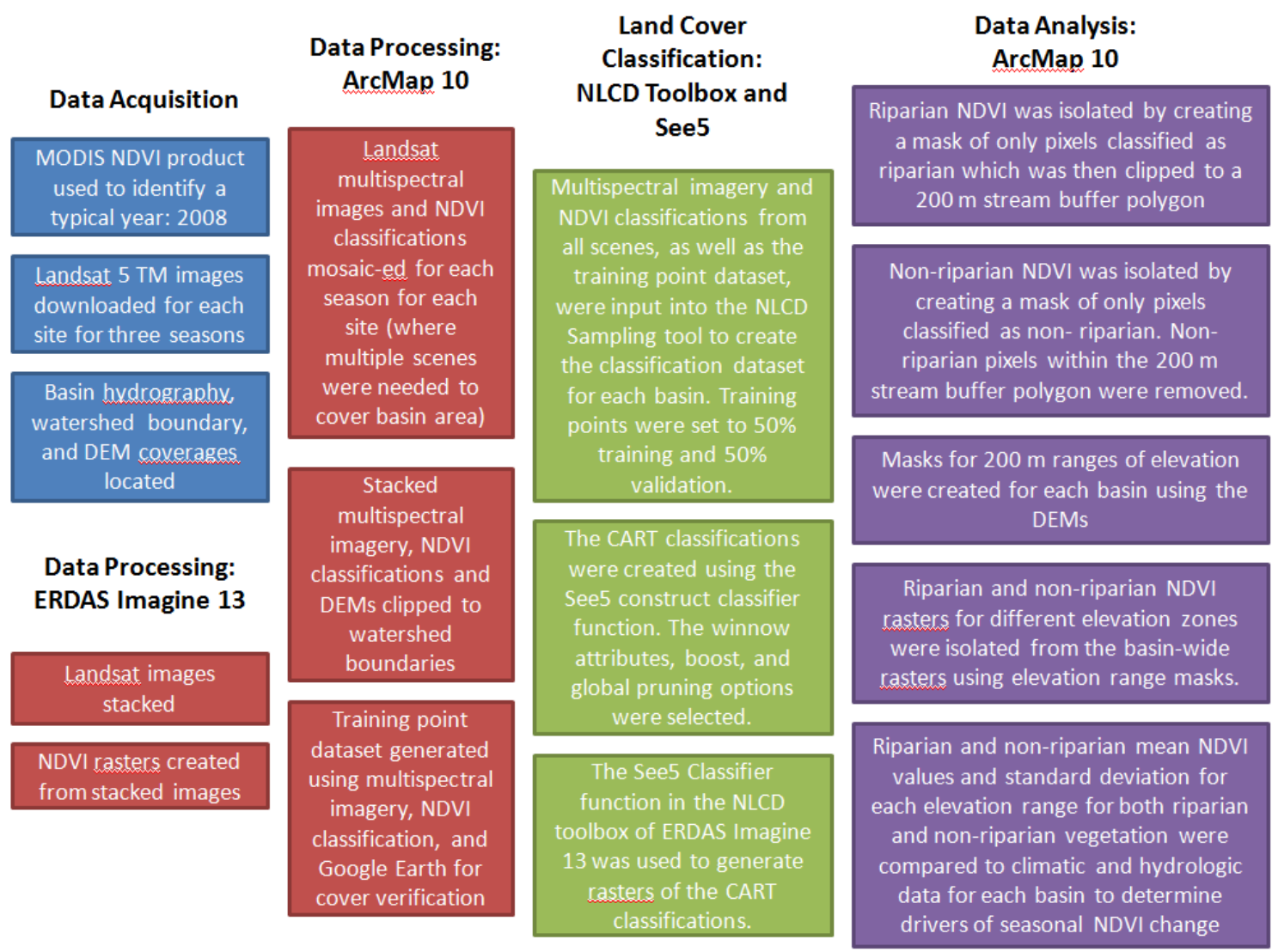

Figure 2. Workflow of spatial data analysis to produce rasters of riparian and non-riparian NDVI for different elevation swaths in four basins in the Basin and Range Province. 
a)

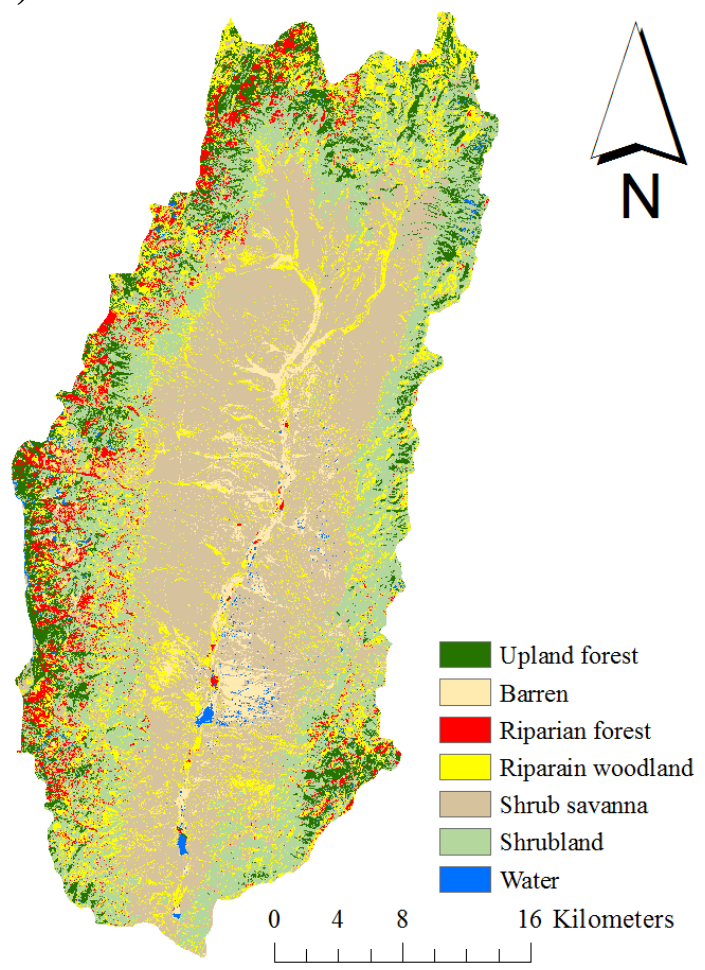

c)

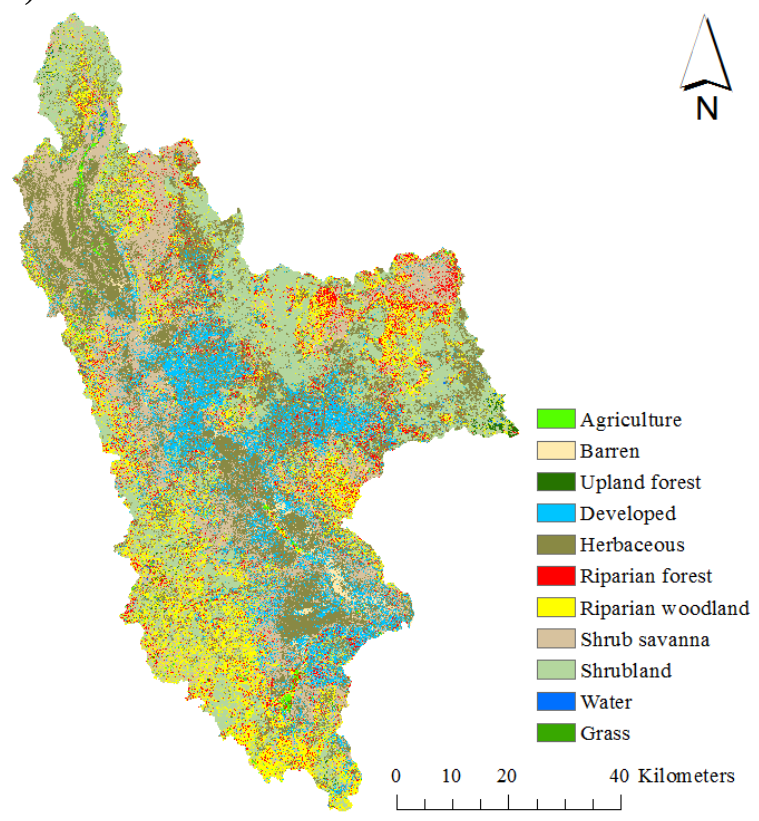

b)

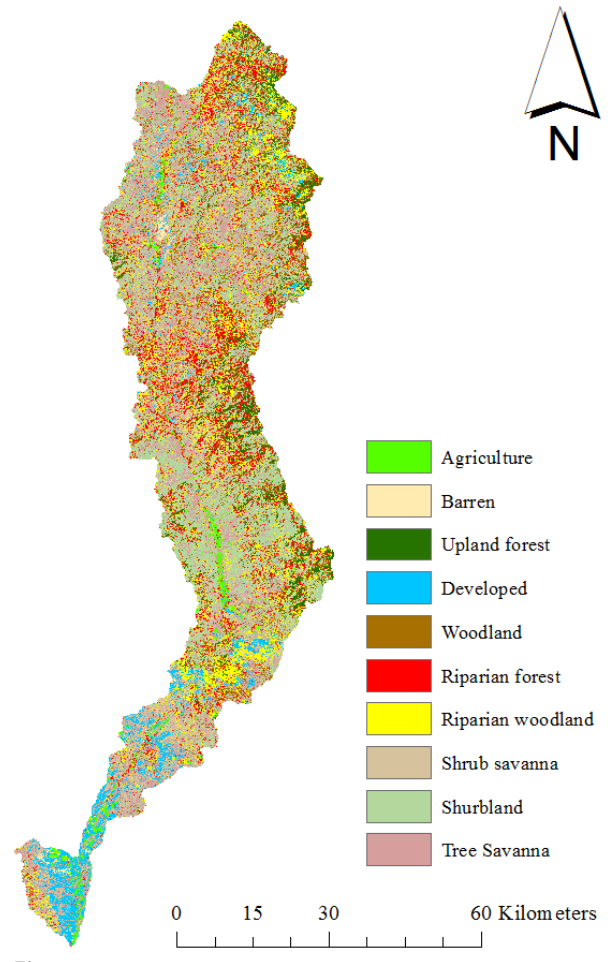

d)

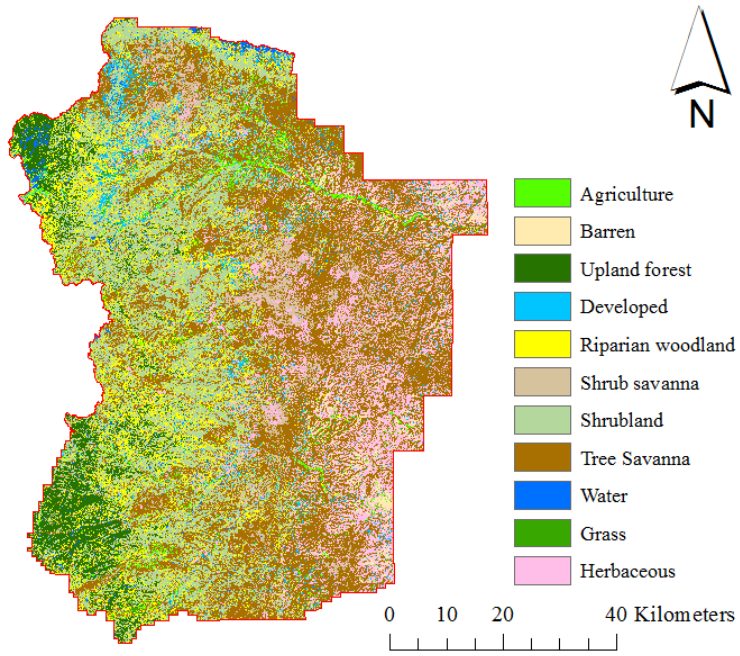

Figure 3. Land cover classifications created using classification and regression tree (CART) models trained with satellite imagery verification data for a) Little Fish Lake Valley (NV); b) Río San Miguel Basin (MX); c) Upper Verde River Basin (AZ); d) Sacramento Mountains/Pecos Slope (NM). 

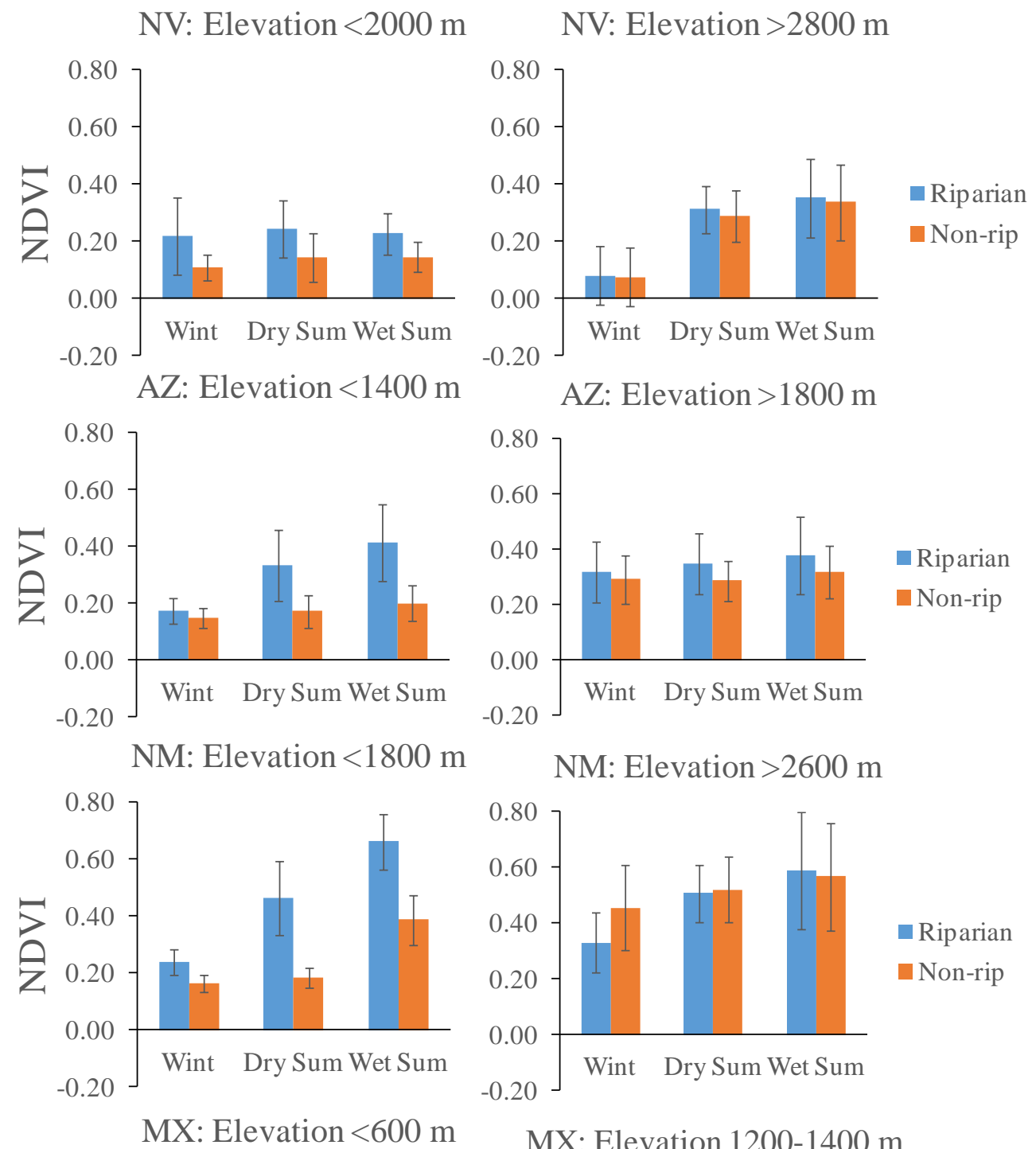

NM: Elevation > 2600 m

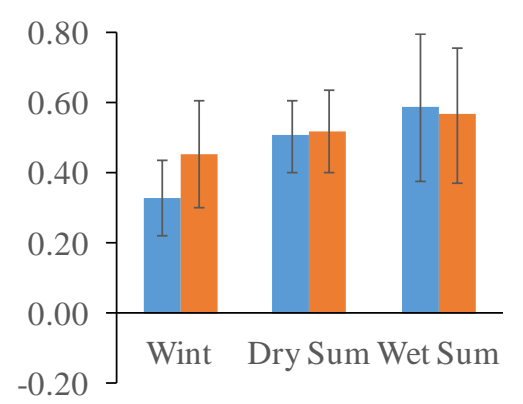

- Riparian

Non-rip
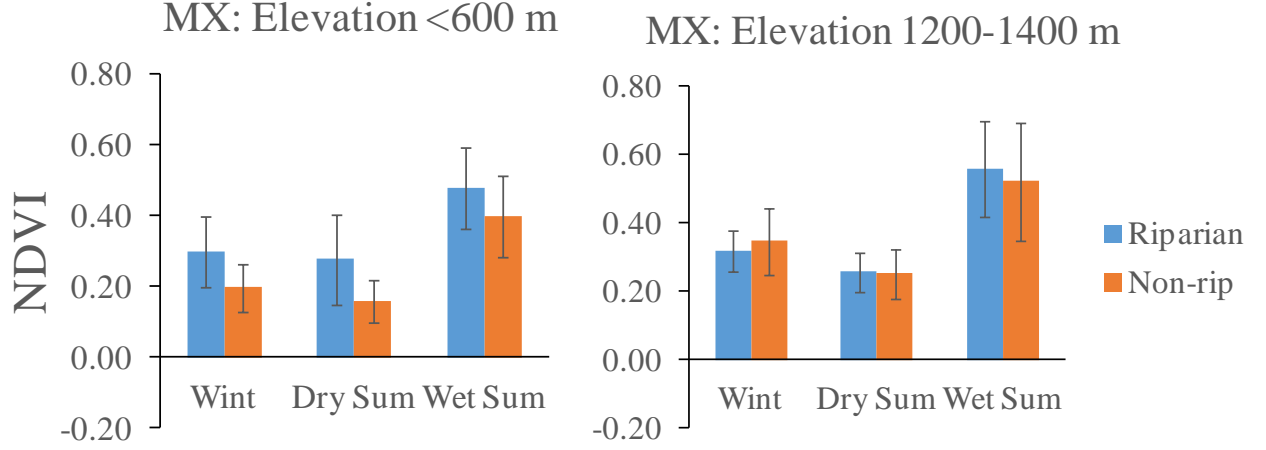

Figure 4. The greatest differences between riparian and non-riparian mean NDVI occur in the lowest elevations of every basin. Only in the lowest elevations of the Verde Valley and Sacramento Mountains was there a significant difference between riparian and non-riparian mean NDVI. 
a)

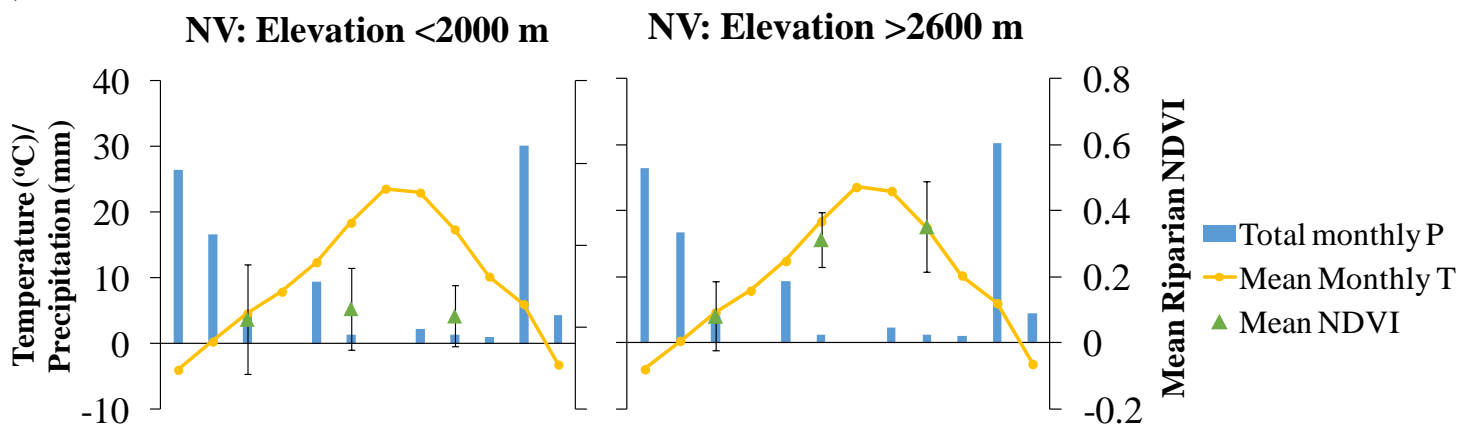

b)

AZ: Elevation $<1400 \mathrm{~m} \quad$ AZ: Elevation $>1400 \mathrm{~m}$

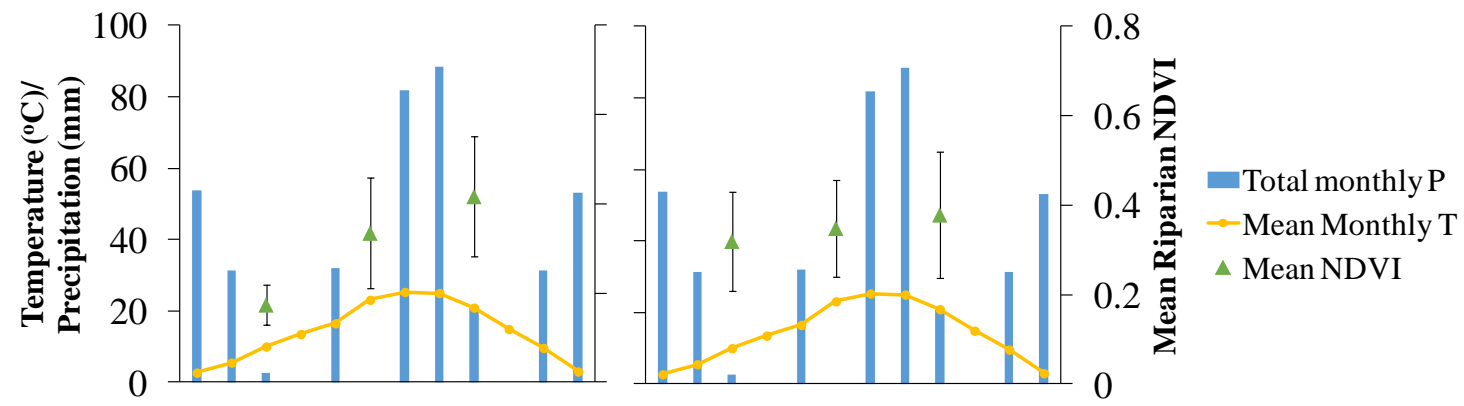

c)

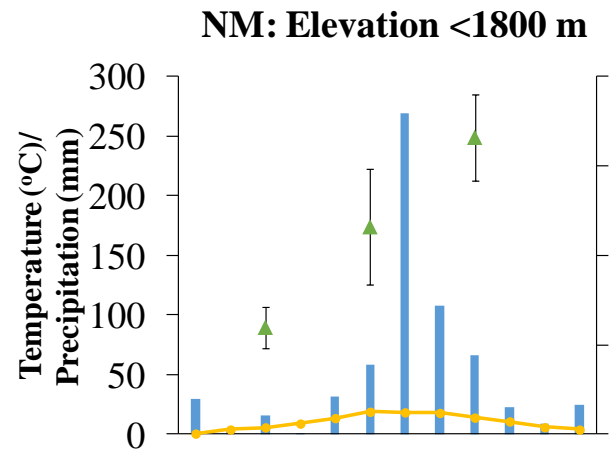

NM: Elevation $>2600 \mathrm{~m}$

d)

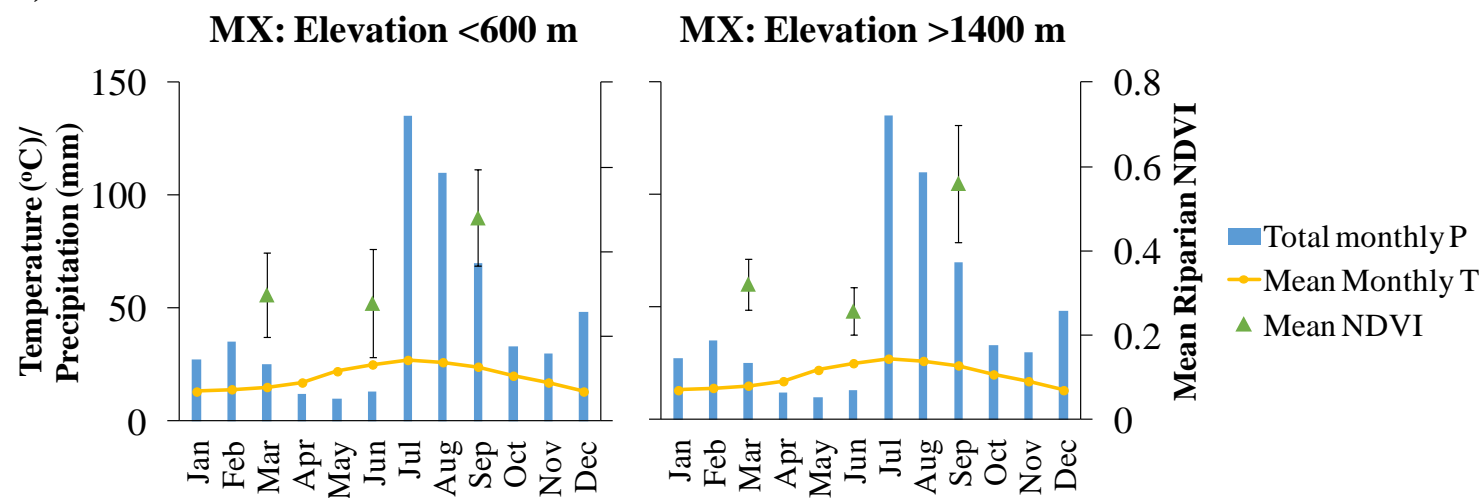

Figure 5. Monthly precipitation, average monthly temperature, and mean riparian NDVI at the end of each season (March, June, and July) for a) Little Fish Lake Valley (NV); b) Upper Verde River Basin (AZ); c) Sacramento Mountains/Pecos Slope (NM); and d) Río San Miguel (MX). 

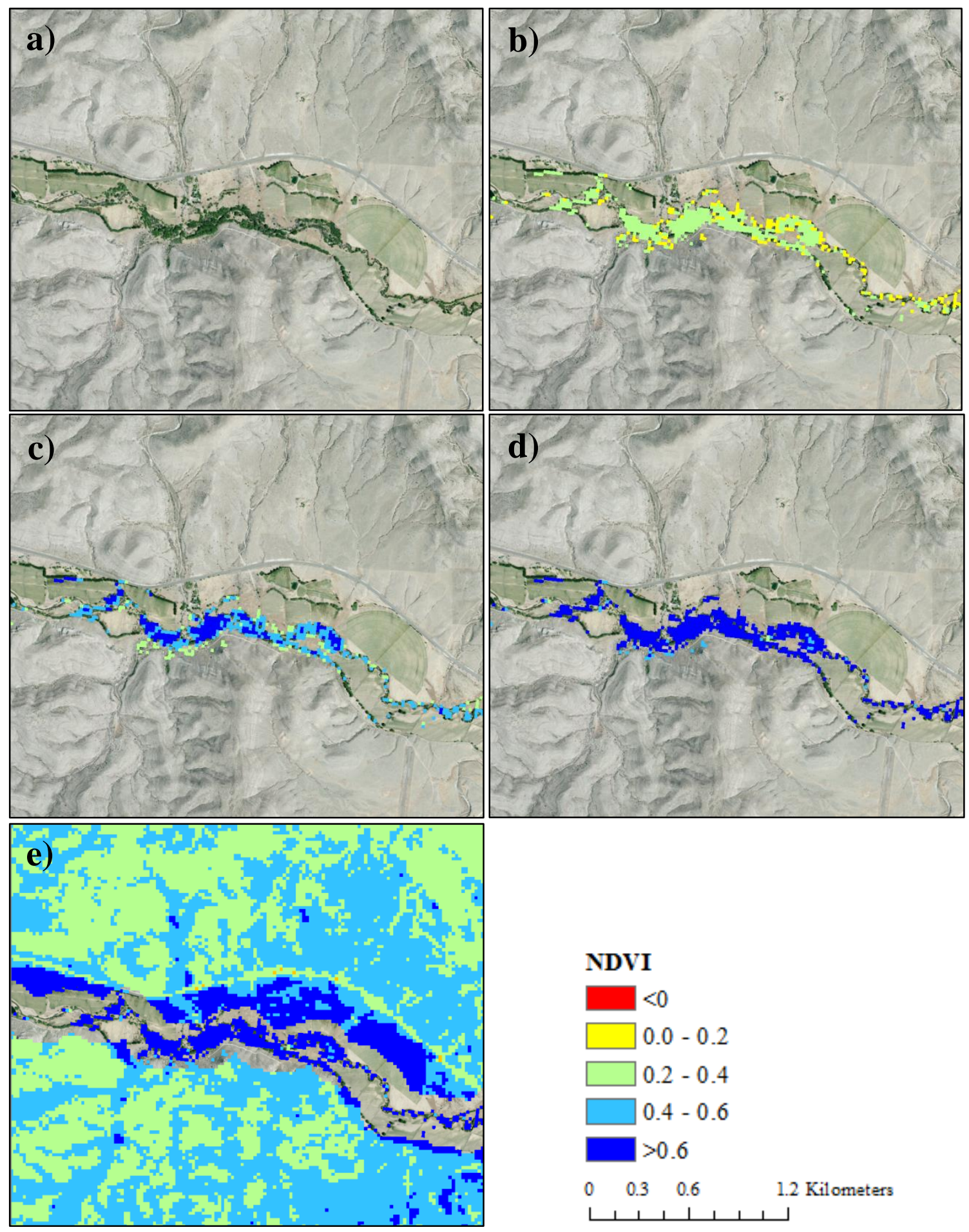

Figure 6. A low-elevation riparian site in the Sacramento Mountains (NM) is depicted a) without data; b) with winter riparian NDVI; c) with early summer riparian NDVI; d) with late summer riparian NDVI; and d) with both riparian and non-riparian late summer NDVI. 

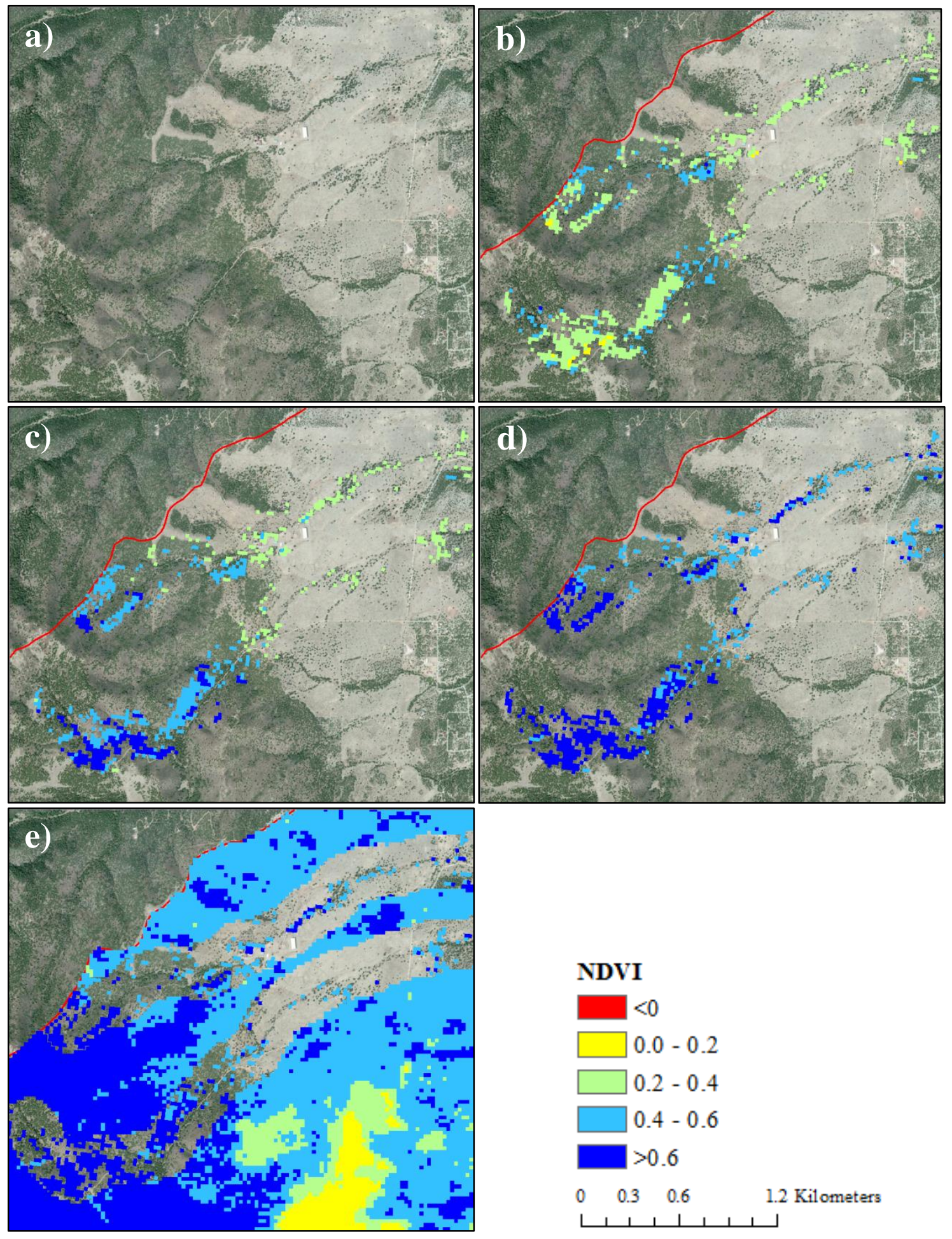

Figure 7. A high-elevation riparian site on the boundary of the Sacramento Mountains (NM) watershed is depicted a) without data; b) with winter riparian NDVI; c) with early summer riparian NDVI; d) with late summer riparian NDVI; and d) with both riparian and non-riparian late summer NDVI. 

a)
b)
c)

\section{Lowest elevation:}

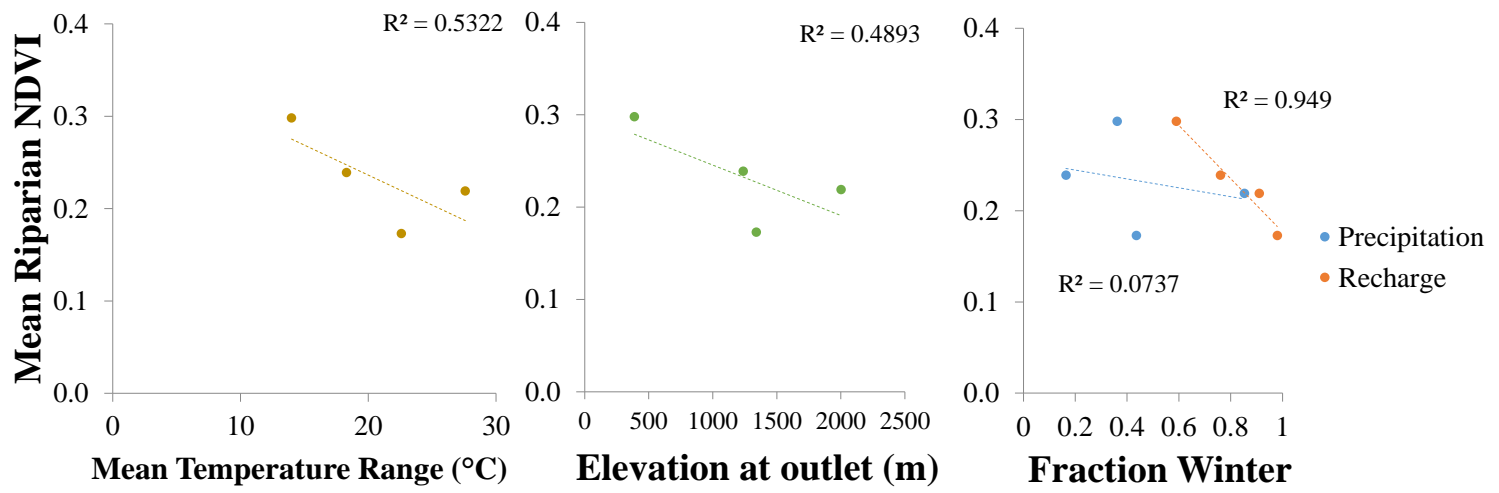

\section{Highest elevation:}

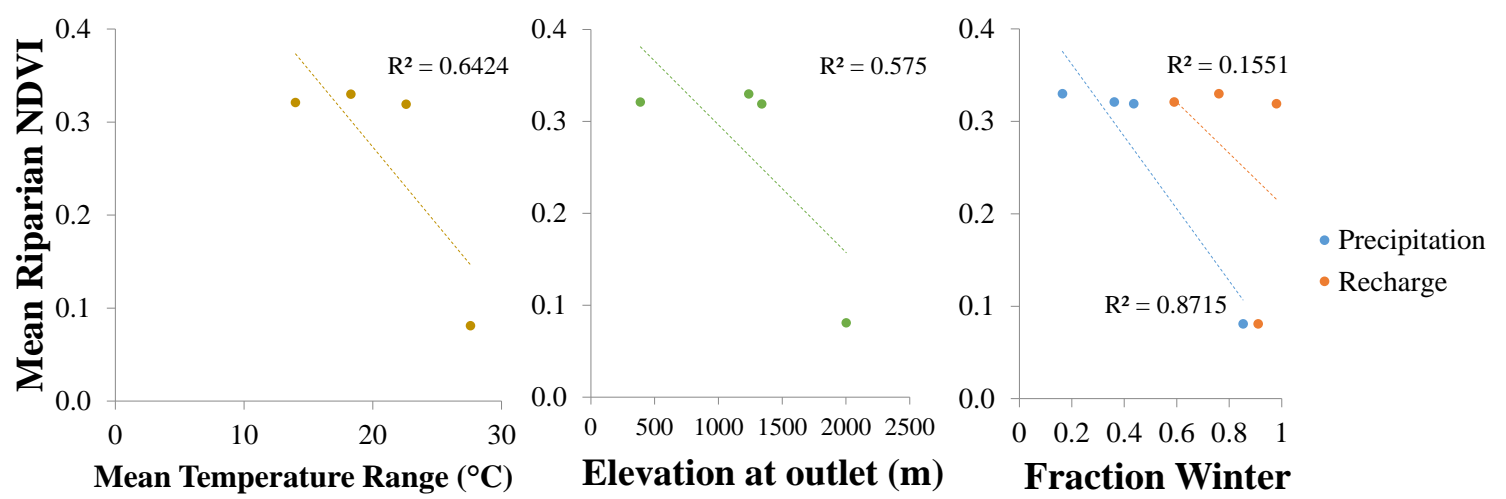

Figure 8. Relationship between mean winter riparian NDVI and a) the range of mean monthly temperatures in a basin; b) elevation of the basin at the outlet; and c) the fraction of winter recharge and precipitation. 
a)

b)

\section{Lowest elevation:}

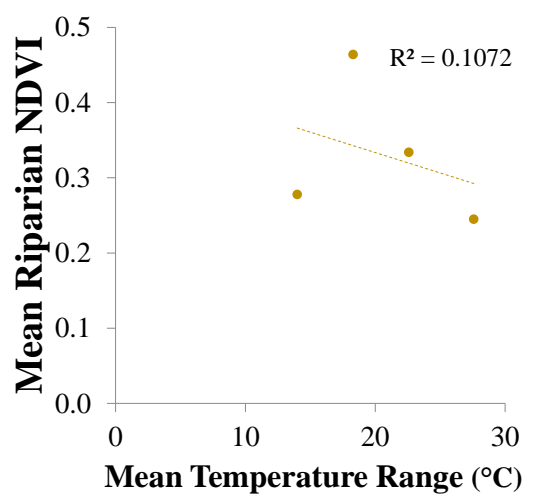

c)

\section{Highest elevation:}

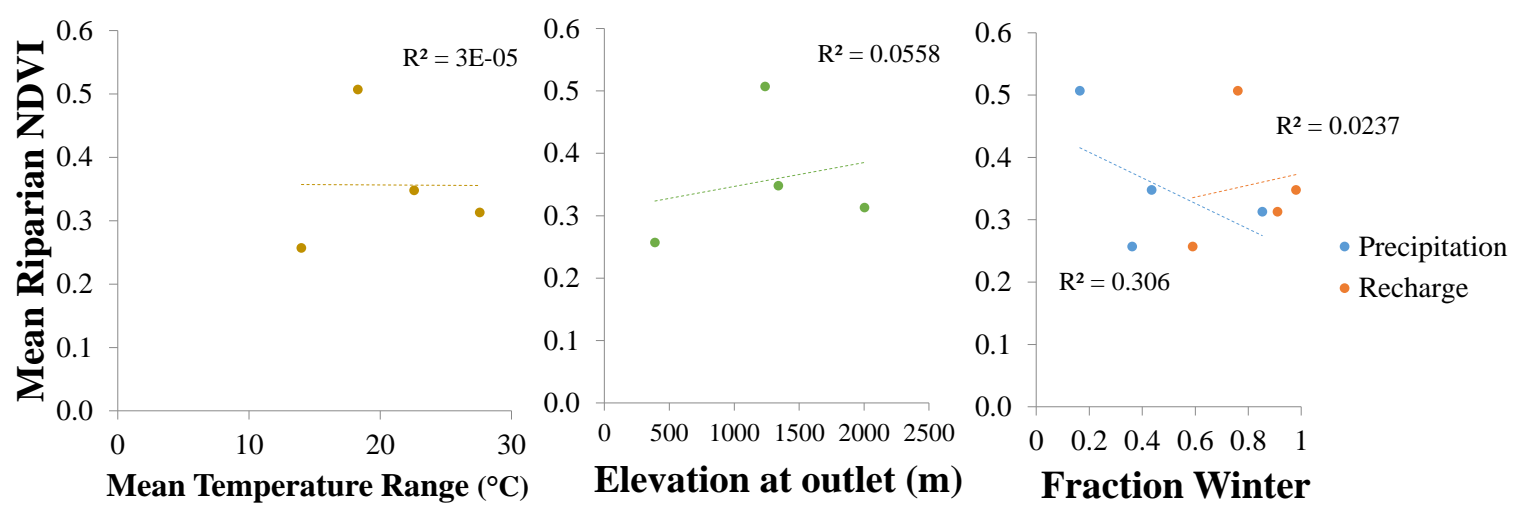

Figure 9. Relationship between mean dry early summer riparian NDVI and a) the range of mean monthly temperatures in a basin; b) elevation of the basin at the outlet; and c) the fraction of winter recharge and precipitation. 

a)
b)
c)

\section{Lowest elevation:}
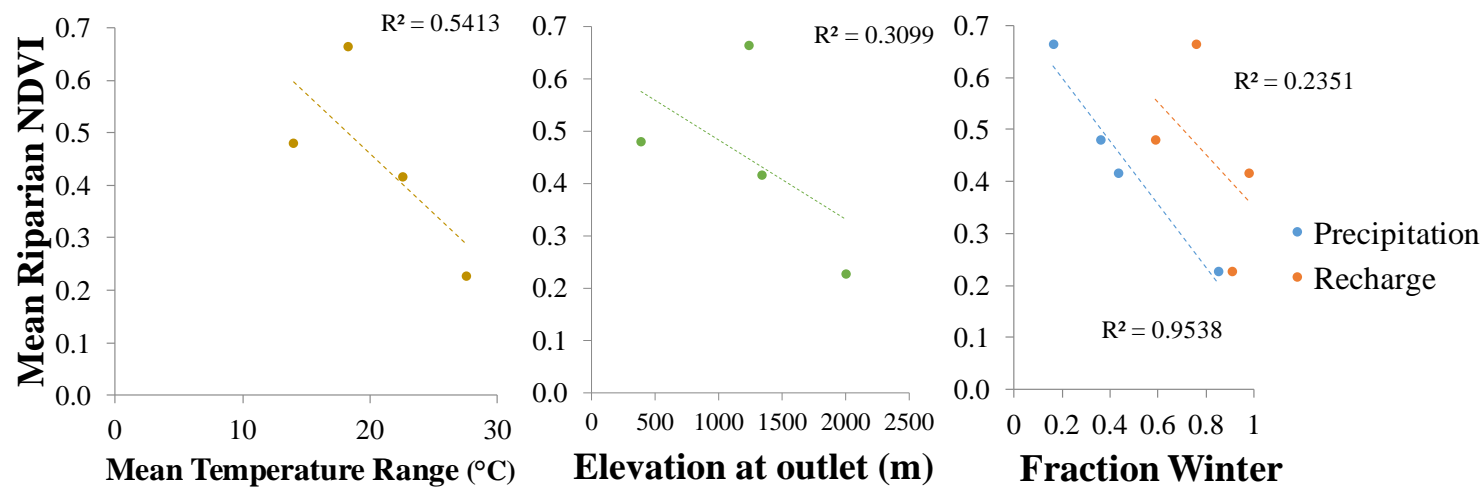

\section{Highest elevation:}
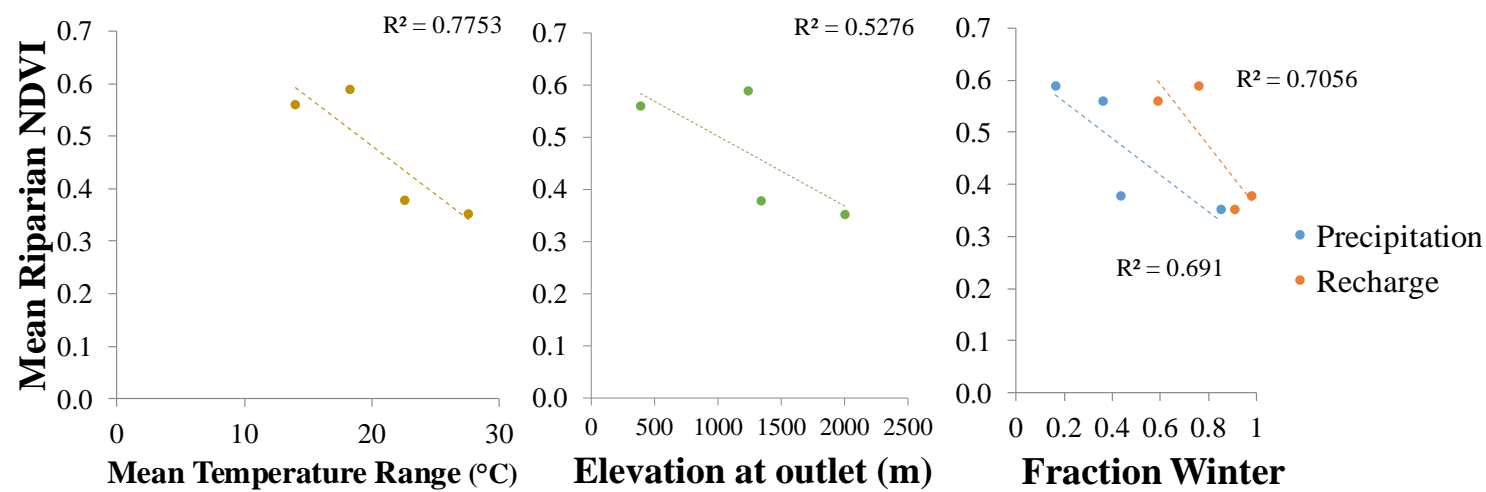

Figure 10. Relationship between mean wet late summer (monsoon) riparian NDVI and a) the range of mean monthly temperatures in a basin; b) elevation of the basin at the outlet; and c) the fraction of winter recharge and precipitation. 